\title{
Initial DOE SNF Standardized Canister Storage Configuration Alternatives Study
}

Daniel A. Thomas

September 2019

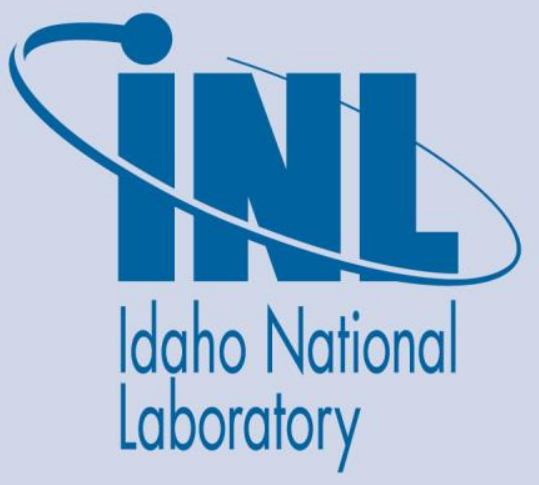

The INL is a U.S. Department of Energy National Laboratory operated by Battelle Energy Alliance 


\section{DISCLAIMER}

This information was prepared as an account of work sponsored by an agency of the U.S. Government. Neither the U.S. Government nor any agency thereof, nor any of their employees, makes any warranty, expressed or implied, or assumes any legal liability or responsibility for the accuracy, completeness, or usefulness, of any information, apparatus, product, or process disclosed, or represents that its use would not infringe privately owned rights. References herein to any specific commercial product, process, or service by trade name, trade mark, manufacturer, or otherwise, does not necessarily constitute or imply its endorsement, recommendation, or favoring by the U.S. Government or any agency thereof. The views and opinions of authors expressed herein do not necessarily state or reflect those of the U.S. Government or any agency thereof. 
INL/EXT-19-55841

Revision 0

\title{
Initial DOE SNF Standardized Canister Storage Configuration Alternatives Study
}

\author{
Daniel A. Thomas
}

September 2019

Idaho National Laboratory

Used Fuel Management, Nuclear Science and Technology Directorate Idaho Falls, Idaho 83415

http://www.inl.gov

Prepared for the

U.S. Department of Energy

Office of Nuclear Energy

Under DOE Idaho Operations Office

Contract DE-AC07-05ID14517 
[Page Intentionally Left Blank] 
Used Fuel Management, Nuclear Science and Technology Directorate

\title{
Initial DOE SNF Standardized Canister Storage Configuration Alternatives Study
}

\author{
INL/EXT-19-55841 \\ Revision 0
}

September 2019

Prepared by:
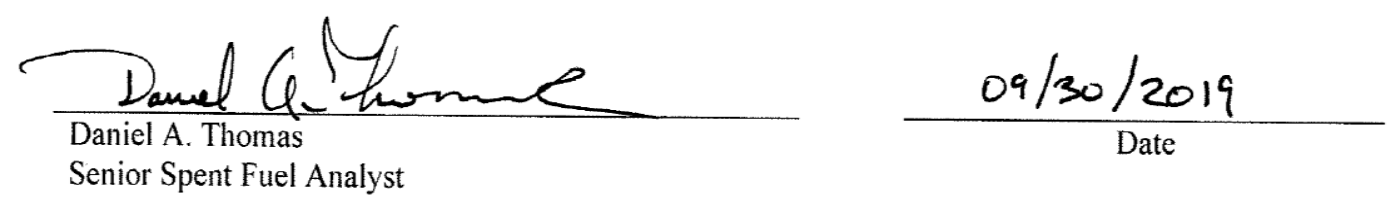

Approved by:

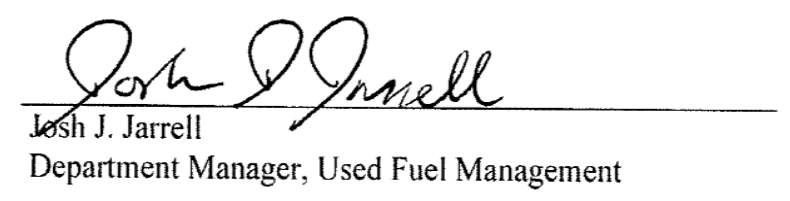

$\frac{9 / 30 / 2019}{\text { Date }}$ 
[Page Intentionally Left Blank] 


\begin{abstract}
This study looks at storage configuration alternatives for United States Department of Energy (DOE) Spent Nuclear Fuel (SNF) Standardized Canisters loaded with DOE-owned SNF. The focus of the study is for the DOE SNF Standardized Canisters that would be packaged in the Idaho Nuclear Technology and Engineering Center (INTEC) area at Idaho National Laboratory (INL), but its general findings are useful across the DOE Complex. The study considered storage in existing facilities, modified existing facilities, new facilities, and new modular systems. The existing INTEC facilities considered in the study include the CPP-603 Irradiated Fuel Storage Facility (IFSF), the CPP-749 Underground Fuel Storage Facility (UFSF), the CPP-666 SNF Wet Storage Basin Facility, CPP-1774 Three Mile Island (TMI) Independent Spent Fuel Storage Installation (ISFSI), and the CPP-2707 Cask Pad Facility. The new facilities considered in the study include the Foster Wheeler designed Idaho Spent Fuel Facility (ISFF) and some conceptual designs. The new modular systems considered in the study include Holtec International's HI-STORM FW, HI-STAR 100, and HI-STAR 100MB; NAC International's MPC, UMS, and MAGNASTOR; and Orano TN's NUHOMS 61BTH, 32PTH1-L, and EOS-37PTH. Based on considerations of various factors, including but not limited to capacity, impact to facility operations, initial capital costs, expenditure rate, licensing issues, and road ready conditions, new modular storage systems from commercial vendors may have clear advantages over other storage alternatives. This is further supported by recent experience with West Valley Demonstration Project (WVDP) storage project for High Level Waste Glass canisters.
\end{abstract}


[Page Intentionally Left Blank] 


\section{SUMMARY}

This study looks at storage configuration alternatives for United States Department of Energy (DOE) Spent Nuclear Fuel (SNF) Standardized Canisters loaded with DOE-owned SNF in the Idaho Nuclear Technology and Engineering Center (INTEC) area at Idaho National Laboratory (INL). The focus of the study is for the DOE SNF Standardized Canisters that would be packaged at INL, but its general findings are useful across the DOE Complex.

The study considered storage in existing facilities, modified existing facilities, new facilities, and new modular systems. The existing INTEC facilities considered in the study include the CPP-603 Irradiated Fuel Storage Facility (IFSF), the CPP-749 Underground Fuel Storage Facility (UFSF), the CPP-666 SNF Wet Storage Basin Facility, CPP-1774 Three Mile Island (TMI) Independent Spent Fuel Storage Installation (ISFSI), and the CPP-2707 Cask Pad Facility. The new facilities considered in the study include the Foster Wheeler designed Idaho Spent Fuel Facility (ISFF) and some conceptual designs. The new modular systems considered in the study include Holtec International's HI-STORM FW, HI-STAR 100, and HI-STAR 100MB; NAC International's MPC, UMS, and MAGNASTOR; and Orano TN's NUHOMS 61BTH, 32PTH1-L, and EOS37PTH.

Based on considerations of various factors, including but not limited to capacity, impact to facility operations, initial capital costs, expenditure rate, licensing issues, and road ready conditions, new modular storage systems from commercial vendors have clear advantages over other options while looking at the entire potential inventory of DOE SNF Standardized Canisters. The use of unmodified existing facilities would have advantages for storing a small number of DOE SNF Standardized Canisters. The use of modified existing facilities would have advantages for storing larger numbers of DOE SNF Standardized Canisters relatively inexpensively, but with mostly upfront costs. The few advantages of a new facility are offset by its high upfront costs and delayed deployment. 
[Page Intentionally Left Blank] 


\section{ACKNOWLEDGEMENTS}

The author would like to thank Holtec International, Nuclear Assurance Corporation International, and Orano $\mathrm{TN}$ for their inputs and information on current commercial industry systems.

The author would also like to thank Fluor staff Russell Cottam and Mark Stubblefield for their inputs and information concerning the current status of INTEC facilities. 
[Page Intentionally Left Blank] 


\section{CONTENTS}

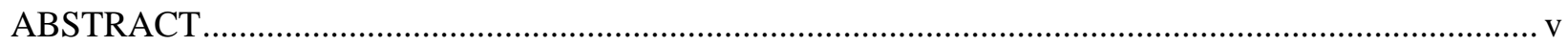

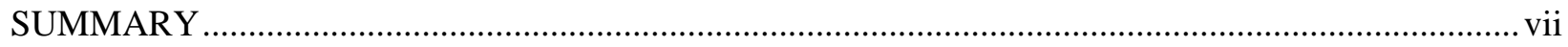

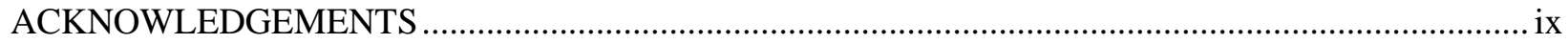

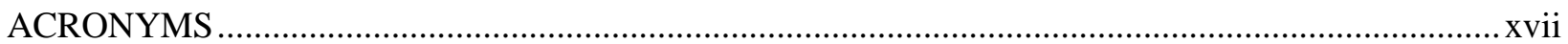

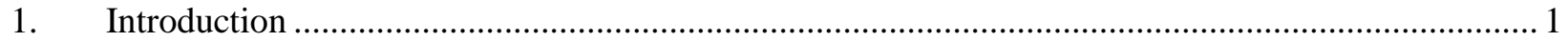

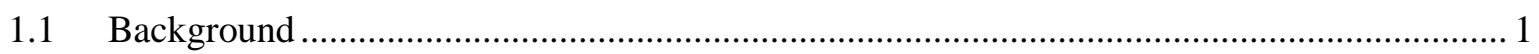

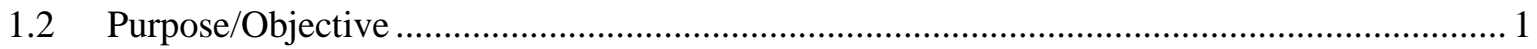

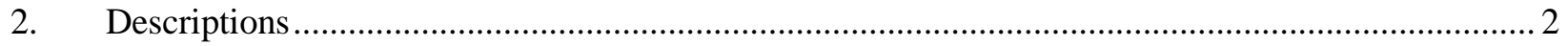

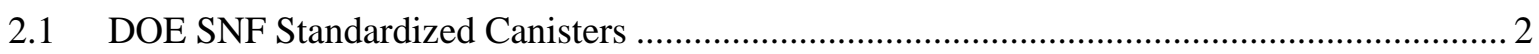

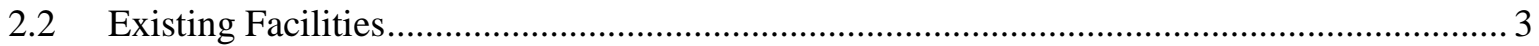

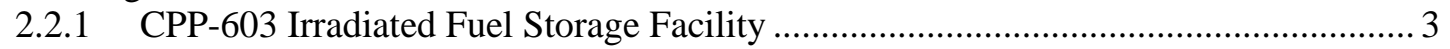

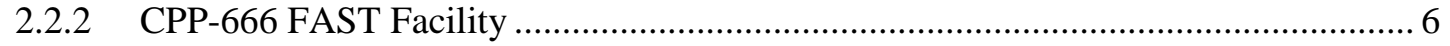

2.2.3 CPP-749 Underground Fuel Storage Facility …........................................................ 7

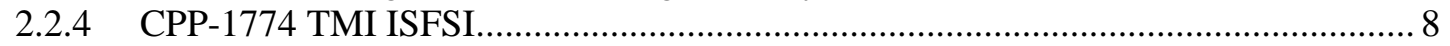

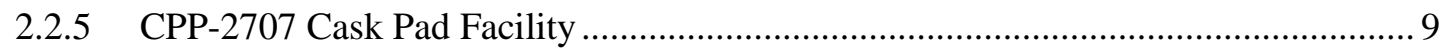

2.2.6 MFC-771 Radioactive Scrap and Waste Facility ..................................................... 10

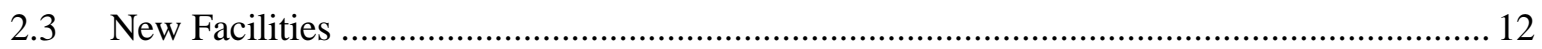

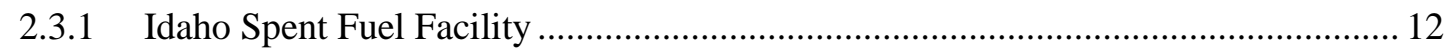

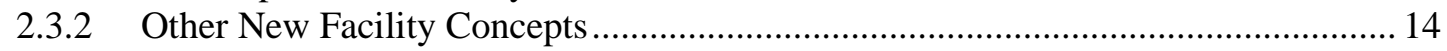

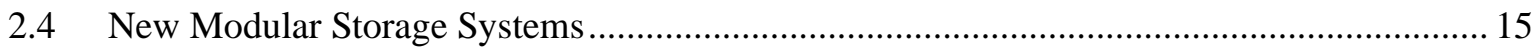

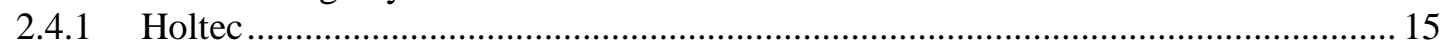

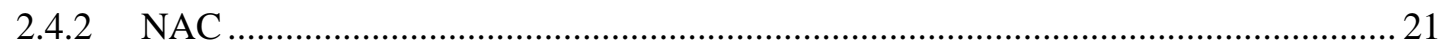

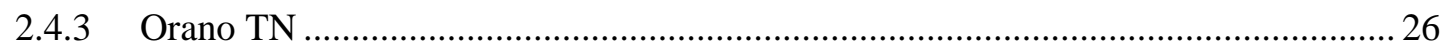

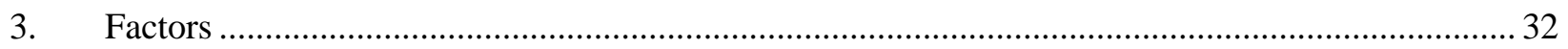

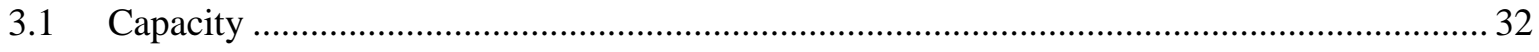

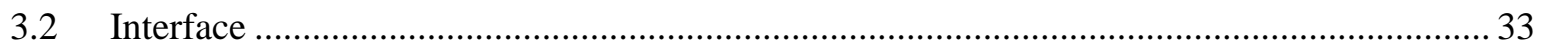

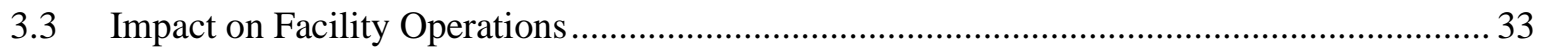

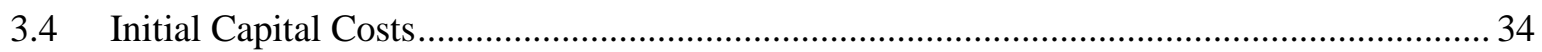

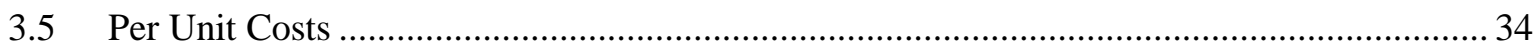

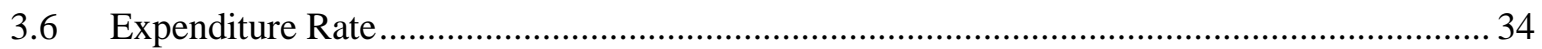

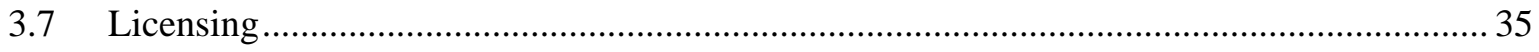

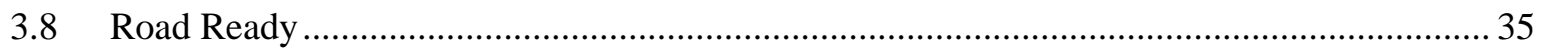

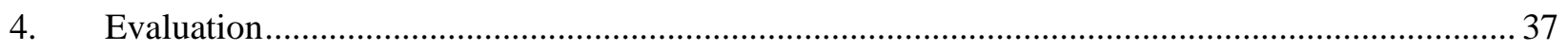

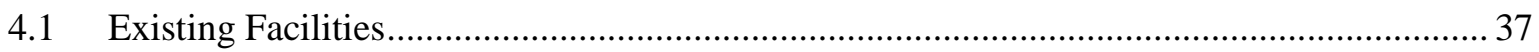

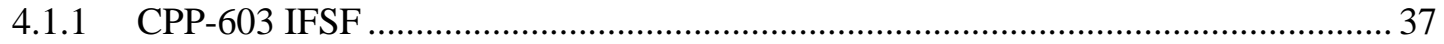

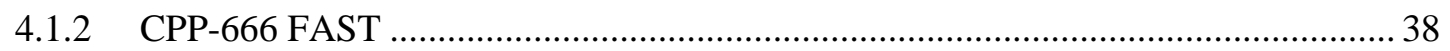

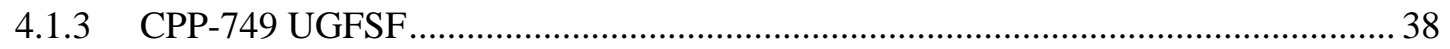

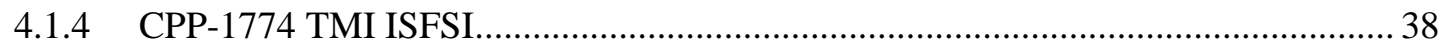




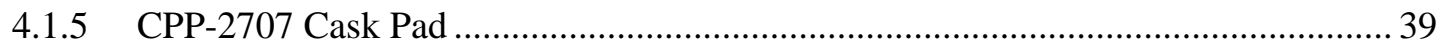

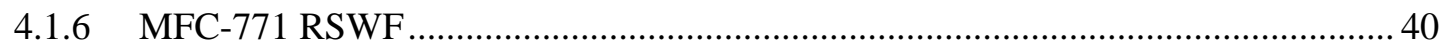

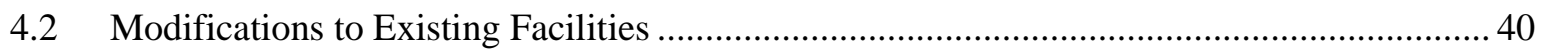

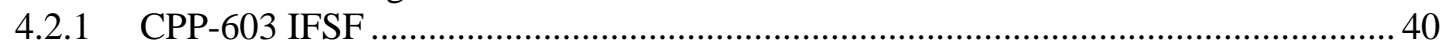

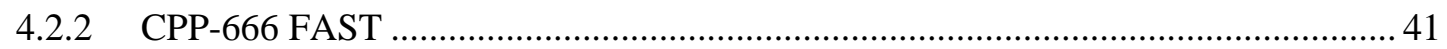

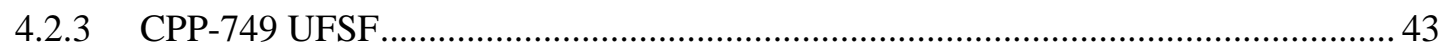

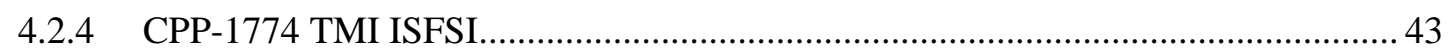

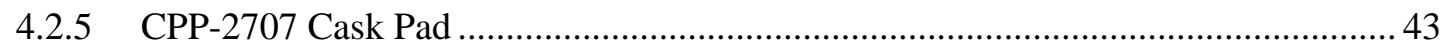

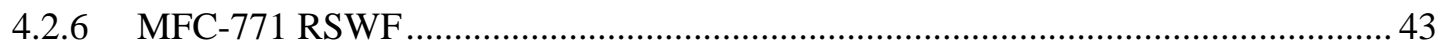

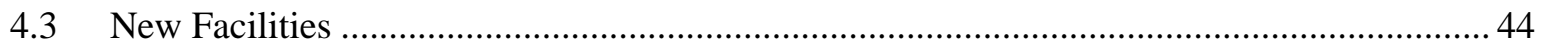

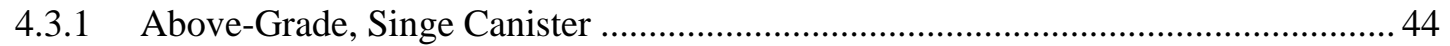

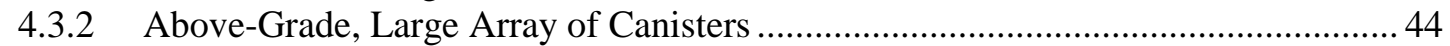

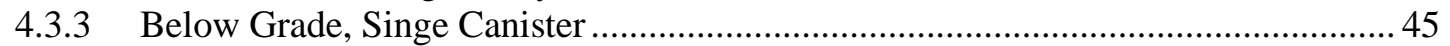

4.3.4 ISF Facility (Below-Grade, Large Array of Canisters) ........................................... 45

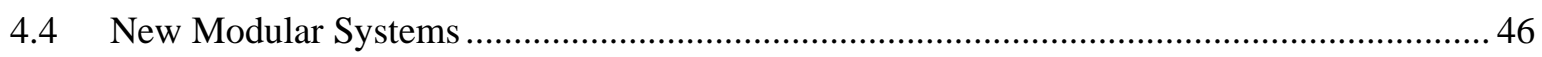

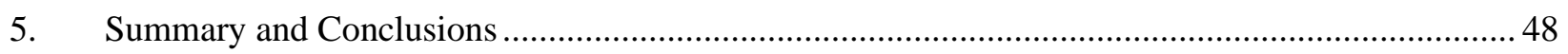

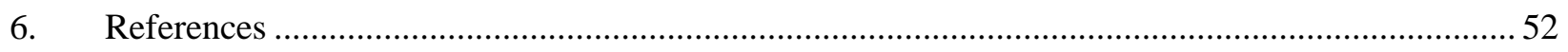

Appendix A Summary of Discussion WVDP Canister Project …........................................................ 53 


\section{FIGURES}

Figure 1. General Cutaway View of DOE SNF Standardized Canister without a Basket .......................... 3

Figure 2. Plan View of CPP-603 Irradiated Fuel Storage Facility............................................................... 4

Figure 3. Section View of CPP-603 Fuel Storage Rack and Fuel Storage Canister. ...................................5

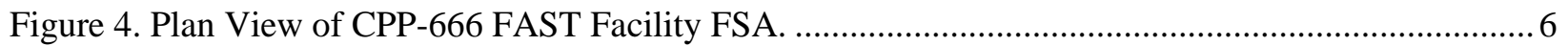

Figure 5. Plan View of CPP-666 FAST Facility's Fuel Storage Pool Area............................................... 7

Figure 6. Plan View of Outdoor Fuel Storage Facility (OFSF) (CPP-749 and CPP-2707)...................... 8

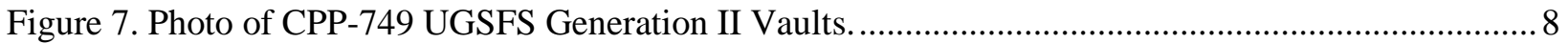

Figure 8. Picture of CPP-1774 with 30 NUHOMS ${ }^{\circledR}$-12T HSMs on Concrete Pad..................................... 9

Figure 9. Picture of 6 Casks on CPP-2707 Cask Pad........................................................................... 10

Figure 10. Picture of MFC-771 RSWF Surface with Diagrams of 4 of 8 Types of Liners. ...................... 11

Figure 11. Cut Away View of ISFF Storage Vault Configuration. ........................................................ 12

Figure 12. Cut Away View of ISFF Storage Vault Configuration. ........................................................ 13

Figure 13. Cut Away View of Loaded ISFF Storage Tube Assemblies.................................................. 14

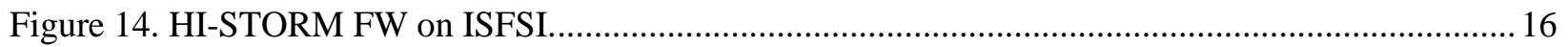

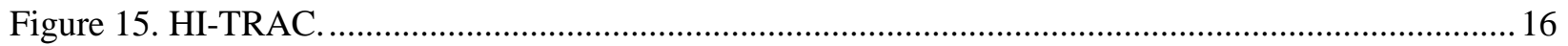

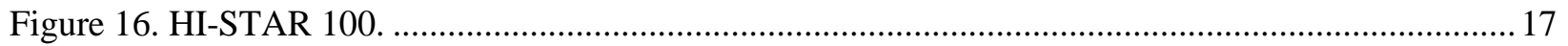

Figure 17. Illustration of a HI-STAR 100MB on a Rail Car. ......................................................... 18

Figure 18. HI-STORM 100 (dark grey colored, left) and HI-STAR 100 (sand colored, right)................. 18

Figure 19. Different Storage Arrangements of HI-STORM 100's....................................................... 19

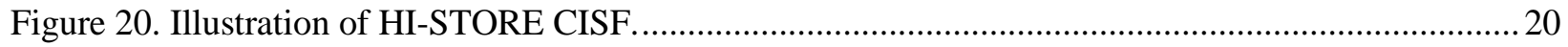

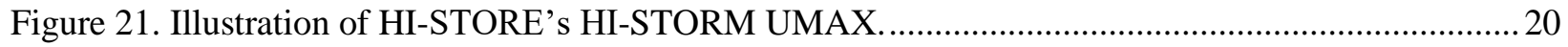

Figure 23. Dry Storage Canisters (Left), Dry Transfer System and NAC-MPC (Right).........................22

Figure 24. NAC-MPC for WVDP (Left). Cask Movement to the Storage Pad (Right)..........................22

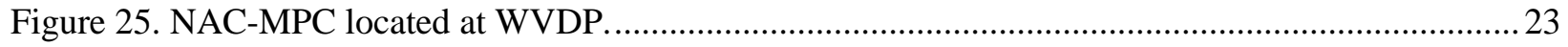

Figure 26. NAC-UMS Casks located at Palo Verde Nuclear Power Plant..............................................24

Figure 27. MAGNASTOR Casks located at Kewaunee Nuclear Power Plant. ........................................24

Figure 28. NAC-STC (Containing and NAC MPC) located at Daya Bay Nuclear Power Plant...............25

Figure 29. Illustration of NAC MPCs (Right) on a CISF Storage Pad. ..................................................25

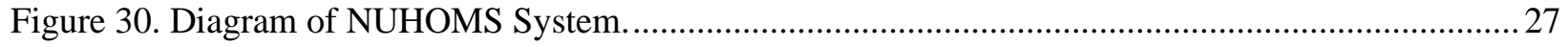

Figure 31. Cutaway View of NUHOMS Transfer Cask and Concrete Storage Module...........................28

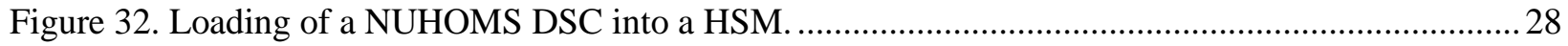

Figure 33. NUHOMS MP197HB transportation cask. .........................................................................29

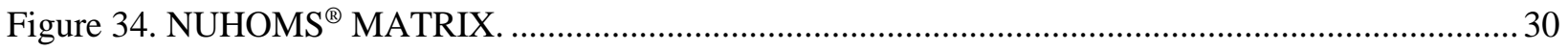




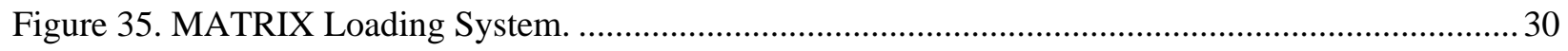

Figure 36. Illustration of NUHOMS HSMs (Left) on a CISF Storage Pad. ............................................. 31

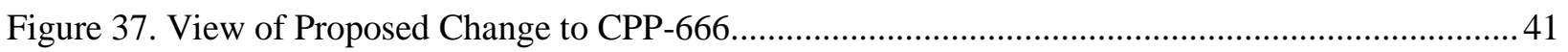

Figure 38. Cutaway View of Proposed Change to CPP-666................................................................. 42 


\section{TABLES}

Table 1. Number of DOE SNF Standardized Canisters in Different Holtec Systems............................ 15

Table 2. Number of DOE SNF Standardized Canisters in Different NAC Systems. ..............................2 21

Table 3. Number of DOE SNF Standardized Canisters in Different TN Systems....................................26

Table 4. Projected Number of Different DOE SNF Standardized Canisters. ........................................... 32

Table 5. Capacity of Storage Facility Alternatives ............................................................................. 48

Table 6. Summary Rating of Storage Facility Alternatives ................................................................... 49

Table 7. Summary Rating of Storage Facility Alternatives for Demo Only Capacity ..............................50

Table 8. Summary Rating of Storage Facility Alternatives Grouped for Limited Capacity ......................50

Table 9. Summary Rating of Storage Facility Alternatives Grouped for Unlimited Capacity ..................50 
[Page Intentionally Left Blank] 


\section{ACRONYMS}

ANSI American National Standards Institute

ASME American Society of Mechanical Engineers

ATR Advanced Test Reactor

BRP Big Rock Point

CACL Contractor Approved Cask List

CFR Code Federal Regulations

CISF Consolidated Interim Storage Facility

CMA Crane Maintenance Area

$\mathrm{CoC} \quad$ Certificate of Compliance

CPP Chemical Processing Plant

CRA Cask Receiving Area

CTC Cask Transfer Car

CTP Cask Transfer Pit

DOE U.S. Department of Energy

DP Decontamination Pad

DSC Dry Shielding Canister

DSC Debris Storage Canister

FAST Fuel And STorage

FDPA Fluorinel Dissolution Process Area

FHC Fuel Handling Cave

FHU fuel-handling units

FMLA fissile material limited area

FPA Fuel Pool Areas

FSA Fuel Storage Area,

FCS Fuel Conditioning Station

GNS General Nuclear Systems

HEPA High Efficiency Particle Absorbing

HI-STAR Holtec International Storage Transport And Repository

HI-STORE Holtec International CISF

HI-STORM Holtec International STORage Module

HI-TRAC Holtec International TRAnsfer Cask

HSM Horizontal Storage Module

HVAC heating, ventilating, and air conditioning

IFSF Irradiated Fuel Storage Facility

INL Idaho National Laboratory

INTEC Idaho Nuclear Technology and Engineering Center

ISA Idaho Settlement Agreement

ISFF Idaho Spent Fuel Facility

ISFP Idaho Spent Fuel Project

ISFSI Independent Spent Fuel Storage Installation 


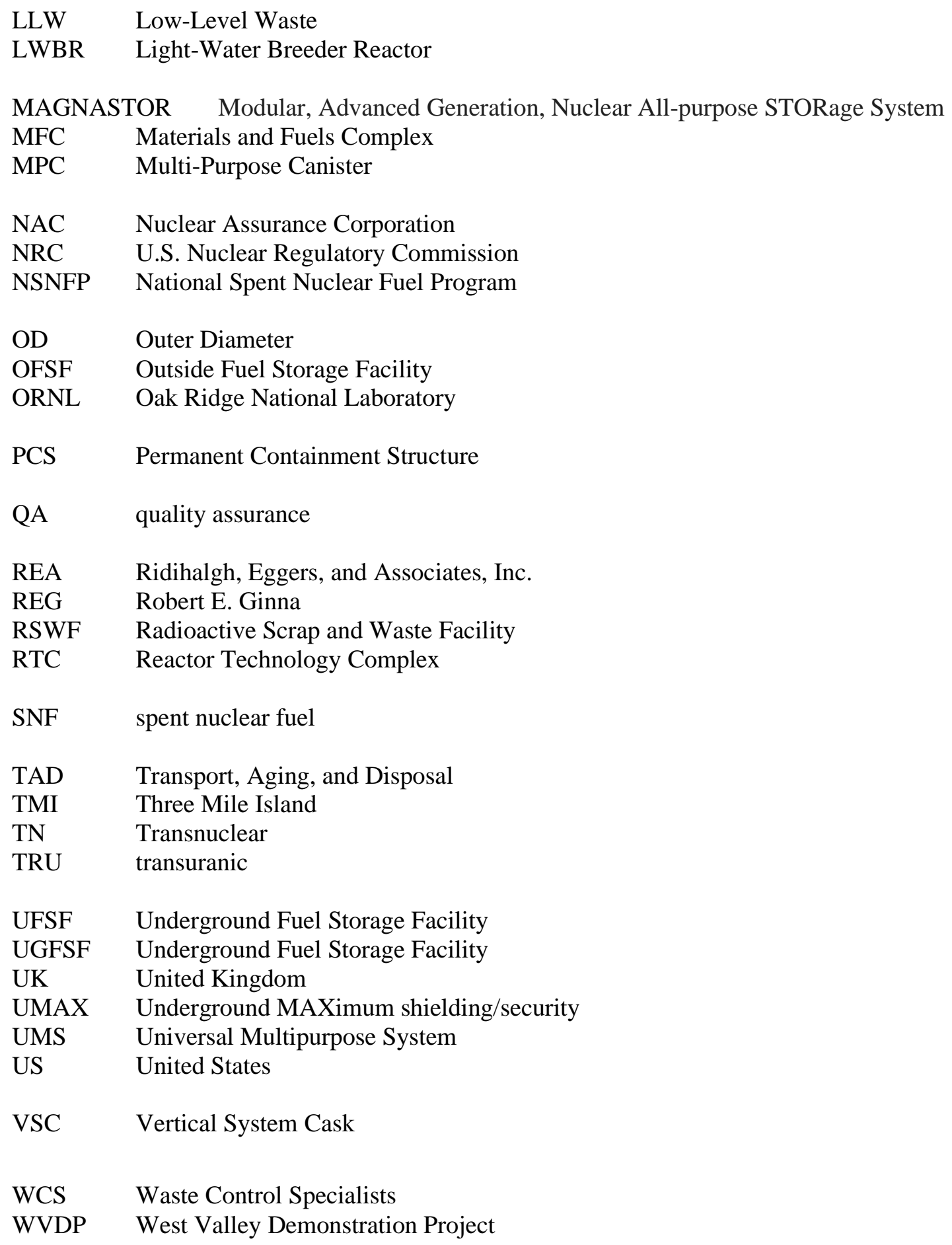




\section{Initial DOE SNF Standardized Canister Storage Configuration Alternatives Study}

\section{Introduction}

\subsection{Background}

Department of Energy (DOE)-owned Spent Nuclear Fuel (SNF) is currently stored in several Idaho Nuclear Technology and Engineering Center (INTEC) facilities on the Idaho National Laboratory (INL) site and across the DOE complex. In some cases, the current storage facilities are reaching capacity and/or are being used beyond their planned lifetimes. A canister type has been proposed, termed the DOE SNF Standardized Canister to allow a broad range of fuels to be loaded, stored, transported, and disposed of by relying on the robustness of the canister instead of the condition of the fuel, thus avoiding the need to reopen the canister after initial loading and handling the SNF. The DOE SNF Standardized Canisters are to be used in conjunction with overpacks (storage, transport, and disposal) to meet the regulatory requirements of each function, similar to the concept of a multi- or triple-purpose (i.e., storage, transportation, and disposal) canister is consistent with the Transportation, Aging, and Disposal (TAD) concept developed for commercial Spent Nuclear Fuel (SNF), as well as the naval canister developed for the Naval Reactors Program. It is anticipated that utilizing DOE SNF Standardized Canisters could significantly reduce the number of canisters needed for storage, increase the loading throughput, and expedite potential backup storage options across the DOE complex.

\subsection{Purpose/Objective}

The purpose of this study is to identify storage configuration alternatives that could be used for the storage of DOE SNF Standardized Canisters at the INL site. Existing and new facilities and configurations are to be considered. The objective is to present the storage configuration alternatives and provide some preliminary information concerning factors to be considered in reviewing one alternative versus another. 


\section{Descriptions}

\subsection{DOE SNF Standardized Canisters}

The DOE SNF Standardized Canister concept was introduced by the National Spent Nuclear Fuel Program (NSNFP) to provide a timely, cost-effective technical solution for DOE-owned SNF management. These DOE SNF Standardized Canisters have the purpose of 1) providing a standard and easy-to-handle unit to confine DOE SNF; 2) providing durable units for storing SNF; 3) providing easily transportable units; and 4) ultimately, providing a unit for final disposal at the national repository, without the necessity of the DOE SNF being removed from the canister or reopening a sealed canister. A large percentage of the DOE-owned SNF lacks qualified information. To minimize the need to characterize the large number of DOE-owned SNF types, the solution was devised to rely on the standardized canister as the basis for compliance with safety requirements.

The design specification for the DOE SNF Standardized Canister requires them to be designed and fabricated using the quality assurance (QA) principles of the American Society of Mechanical Engineers (ASME) code to support the bases for a low-failure probability argument (i.e., ASME Section III Division 3). DOE SNF Standardized Canister are to be leak-tested in accordance with procedures in compliance with the American National Standards Institute (ANSI) N14.5, 1987, American National Standard for Radioactive Materials-Leakage Tests on Packages for Shipment.

The design specification [1] mandates the DOE SNF Standardized Canister have an 18-inch or 24-inch diameter and approximate 10-foot or 15-foot length. The canister shells are to be fabricated from welded or seamless ASME SA312,316L stainless steel pipe. The top and bottom heads are to be dished and flanged, fabricated from ASME SA240, 316L stainless steel, and butt-welded to the shell. The canister designs are to incorporate an energy absorbing skirt that deforms on impact during accidental drop events, providing a significant amount of protection to the actual containment boundary of the canister, including the welds. This deformed skirt could be removed (cut off), if necessary, without disrupting the canister's containment, enhancing the canister's ability to still fit into other containers (e.g., a waste package) after a drop event. The canister design is to also incorporate the option of a threaded vent plug in the top and bottom heads. These plugs could be used for several functions, including canister draining, inerting, leak testing, venting, monitoring, and remote inspection. Installation or removal of the plug(s) is to be performed while inside a hot cell or other approved area. Plugs are to be seal-welded using an appropriately qualified process prior to transport. [2]

A general view of the DOE SNF Standardized Canister, and information about the four based designs (dimensions and maximum masses) are shown in Figure 1. Details of the canister designs can be found in various drawings [3], [4]. 


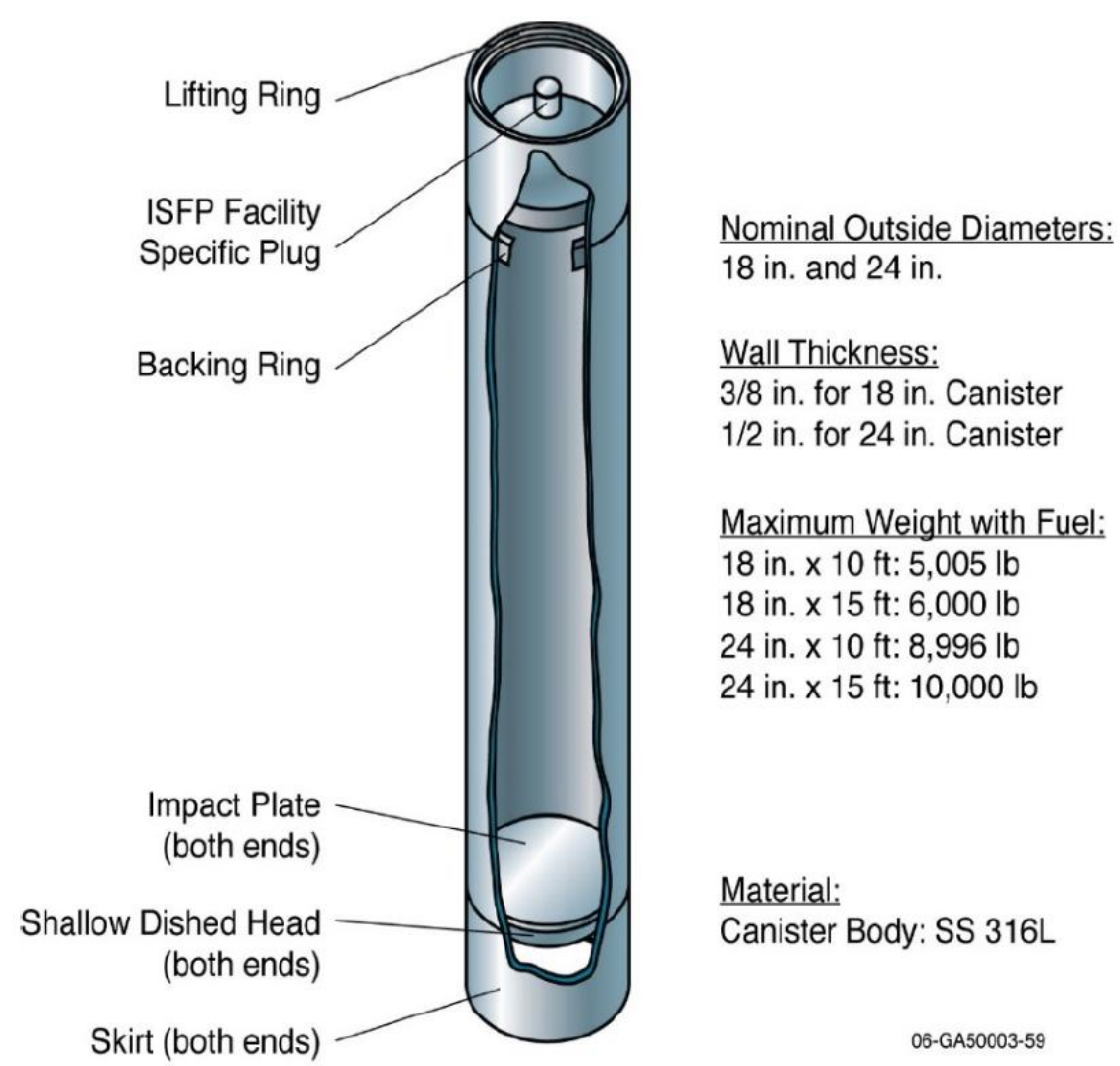

Figure 1. General Cutaway View of DOE SNF Standardized Canister without a Basket

\subsection{Existing Facilities}

The following sections provide descriptions of existing INL facilities where DOE SNF Standardized Canisters could be stored.

\subsubsection{CPP-603 Irradiated Fuel Storage Facility}

The CPP-603 Irradiated Fuel Storage Facility is located in the southwest corner of the INTEC area of INL. Construction of the Irradiated Fuel Storage Facility (IFSF) portion of CPP-603 was completed in December 1974. The IFSF was designed to provide safe, interim, fuel storage pending retrieval of the stored fuel for final disposal. To meet this goal, the main operations performed in the IFSF include receiving nuclear fuels from other facilities, repackaging and conditioning fuels for interim storage, safely storing fuels, storing fuel-loaded storage casks on an interim basis, and packaging fuels for removal from the facility. The facility mission will continue until all fuels have been removed. It is projected that the facility will continue to store fuel until 2035. This facility is monitored by the Radiation Protection Program to ensure protection of facility workers.

CPP-603 facility's IFSF functional areas include the (1) truck bays (including Cask Receiving Area (CRA), east/west truck bay, and north/south truck bay), (2) Cask Transfer Pit (CTP) and Permanent Containment Structure (PCS), (3) Fuel Handling Cave (FHC), (4) Fuel Storage Area (FSA), (5) control room/instrument room, (6) Crane Maintenance Area (CMA), and (7) Decontamination Pad (DP). Fuel, packages, and heavy equipment are moved into the facility via the truck bays, then into the PCS and CTP 
into the FHC using the Cask Transfer Car (CTC). After various operations in the FHC, fuel in storage canisters are moved into the FSA via a Shuttle Bin and placed in storage racks with the crane (CRN-GSF101).

The CPP-603 FSA houses the carbon-steel storage rack, which measures $36 \mathrm{ft}$ wide $\times 68 \mathrm{ft}$ long $\times 11$ $\mathrm{ft}$ tall. The rack supports the 636 fuel Storage Canisters, each of which is 18 in. in diameter and approximately $11 \mathrm{ft}$ long. The rack has 38 rows of canisters, alternating 17 and 18 canisters per row. Some of the rows do not have the entire width of 17 or 18 canisters, as shorter rack rows exist around the opening for the shuttle bin. The rack sits on the fuel storage area floor; and the storage rack supports the canisters approximately $2-1 / 2$ in. above the facility floor. The Fuel Storage Canisters hang from the FSA rack by their top lip. Figure 2 shows a plan view of CPP-603 and Figure 3 shows a section of FSA rack and Fuel Storage Canister section view.

A detailed description of the CPP-603 IFSF is provided in Chapter 2 of the Safety Analysis Report for the Irradiated Fuel Storage Facility (IFSF) [5].

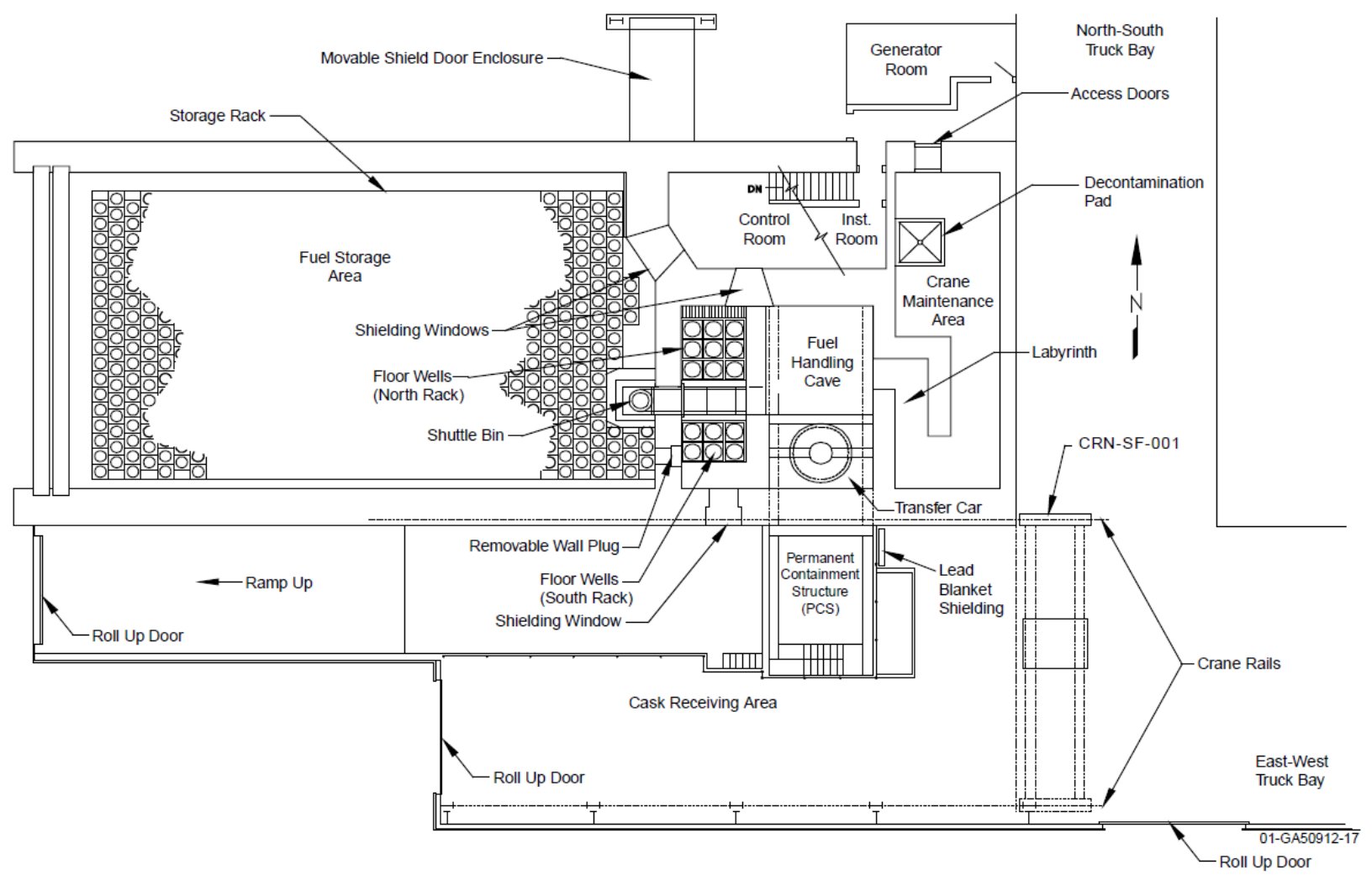

Figure 2. Plan View of CPP-603 Irradiated Fuel Storage Facility. 


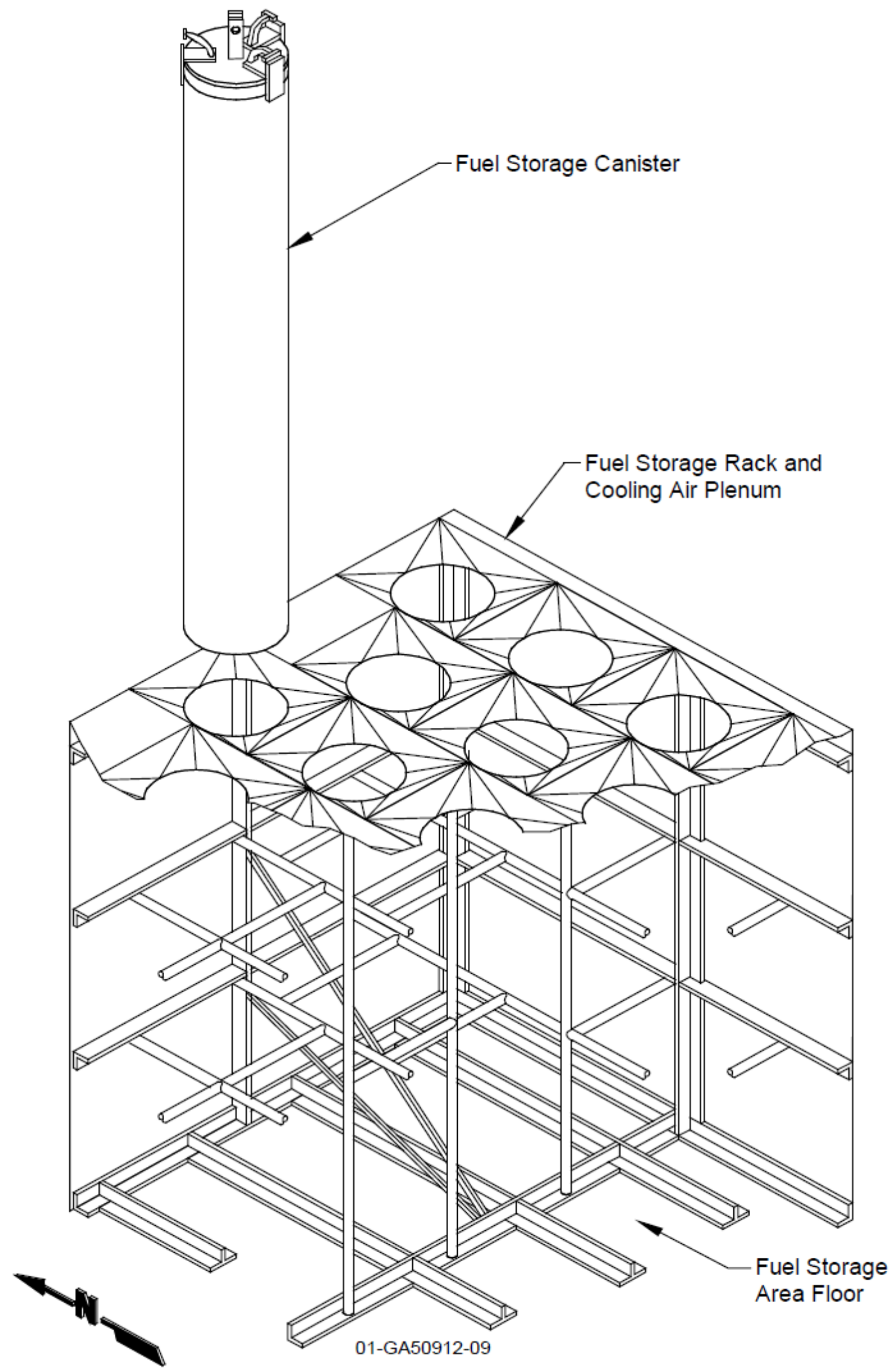

Figure 3. Section View of CPP-603 Fuel Storage Rack and Fuel Storage Canister. 


\subsubsection{CPP-666 FAST Facility}

The CPP-666 FAST (Fuel And STorage) facility has two separate areas, the Fuel Storage Area (FSA), and the Fluorinel Dissolution Process Area (FDPA). The original mission of the FSA was to provide shortterm underwater storage of fuels destined to be reprocessed in the FDPA. When the decision to end fuel reprocessing was made in April 1992, the mission of the FSA changed to receiving and storing nuclear fuel. All the fuel in the FSA Wet Storage Basins/pools are to be removed by December 31, 2023 in accordance with the settlement agreement with the State of Idaho, the DOE, and the U.S. Navy. The FDPA is being used for characterization, repackaging, and loading of remote-handled transuranic (TRU) waste to meet off-site disposal criteria.

The CPP-666 FSA functional areas include the (1) truck receiving area; (2) cask receiving and decontamination area; (3) unloading area (including unloading and isolation pools); (4) storage pool area; (5) cutting pool area; (6) transfer channel; (7) water treatment area; (8) transfer channel extension; (9) main control room (now used as the shift operating base); (10) support areas, such as heating, ventilating, and air conditioning (HVAC); (11) office areas and other miscellaneous support areas consisting of storage rooms, rest rooms, change rooms, and showers; and (12) transfer channel ramp to the FDPA. Figure 4 shows the general layout of the areas within the FSA.

The fuel storage pool area is shown in Figure 5. The six interconnected fuel storage pools, divided by concrete walls, contain the underwater fuel storage racks. Each pool measures $31 \mathrm{ft}$ (north to south) by $46.5 \mathrm{ft}$ (east to west), resulting in a floor area of approximately $1,442 \mathrm{ft}^{2}$ for each pool. Pools 1 and 2 are $41 \mathrm{ft}$ deep and Pools 3, 4, 5, and 6 are $31 \mathrm{ft}$ deep; nominal water depths are 40 and $30 \mathrm{ft}$, respectively. Each fuel storage pool has a gate opening on the east wall that provides access to the transfer channel. The gate opening for Pools 1 and 2 extends $23 \mathrm{ft} 9 \mathrm{in}$. below grade, and the width tapers from $11 \mathrm{ft} 1 \mathrm{in}$. at the top, to $6 \mathrm{ft}$ at the bottom. The opening for the remaining pools extends $20 \mathrm{ft}$ below grade and the width tapers from $11 \mathrm{ft} 1 \mathrm{in}$. at the top, to $6 \mathrm{ft} 8 \mathrm{in}$. at the bottom. The entire fuel storage pool area is constructed of reinforced concrete, and each pool is lined with stainless steel. Fuel storage racks are placed in each of the six fuel storage pools. Additionally, Pool 5 has SLS equipment, and ancillary equipment. As mentioned previously, two 10-ton fuel handling cranes (CRN-FS-901 and -902) are used in the storage pool area to move fuel.

A detailed description of the CPP-666 FAST Facility is provided in Chapter 2 of the Safety Analysis Report for the CPP-666 Fuel Storage Area (FSA) [6].

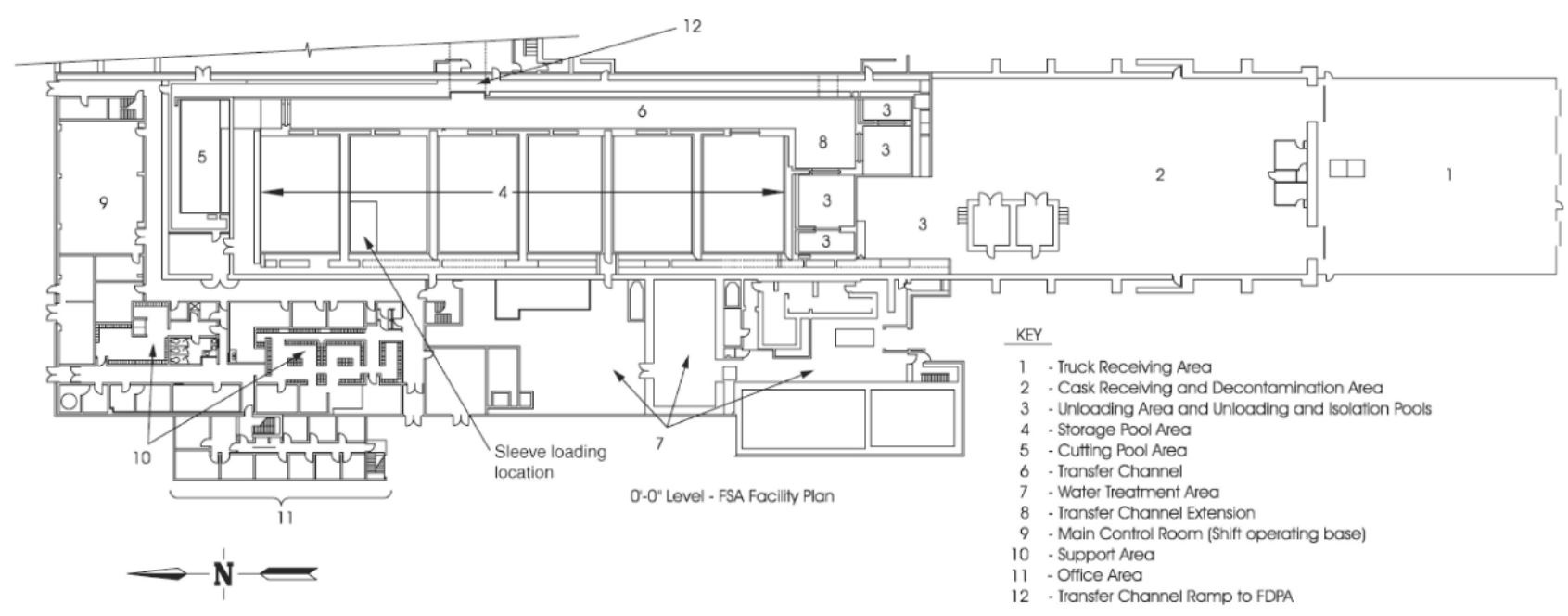

Figure 4. Plan View of CPP-666 FAST Facility FSA. 


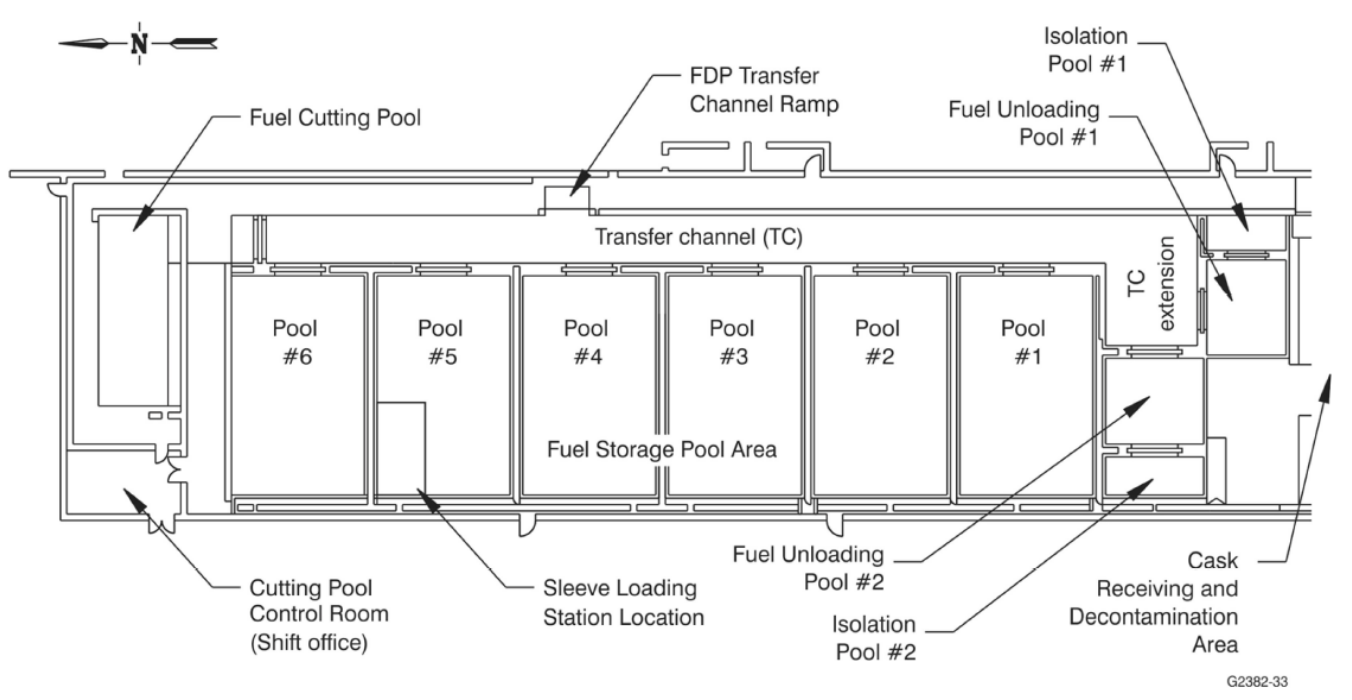

Figure 5. Plan View of CPP-666 FAST Facility’s Fuel Storage Pool Area.

\subsubsection{CPP-749 Underground Fuel Storage Facility}

The CPP-749 Underground Fuel Storage Facility (UGFSF) is part of the Outside Fuel Storage Facility (OFSF). The OFSF is designed to provide safe storage of fuel and to provide retrieval capabilities for eventual transfer of the fuel out of the facility. The facility consists of two defined areas, (1) the underground fuel storage portion of the facility where fuel-handling units (FHUs) are stored in underground storage vaults (designated as CPP-749) and (2) a concrete pad on which fuel-loaded casks are stored (designated as CPP-2707). In addition to these two defined areas, there are three small ATR Complex casks containing small amounts of fuel located within the CPP-749 area and one fissile material limited area (FMLA) located in a cargo container within CPP-2707.

The CPP-749 portion of this outdoor facility consists of a fenced enclosure containing 218 vertically oriented fuel storage vaults. The vaults are installed below grade with the tops slightly above grade. The vaults are principally 30-in.-diameter carbon-steel pipes, closed on the bottom, and placed in holes that were drilled in the existing soil in the area. These underground fuel storage vaults provide storage and allow for eventual retrieval of the fuel. The CPP-749 facility proper is enclosed by a gated, chain-link fence, and occupies an area of approximately 260,150 $\mathrm{ft}^{2}$ (about 6 acres). A chain-link fence also separates the unirradiated Light-Water Breeder Reactor (LWBR) fuel storage vaults from the remainder of CPP-749 for safeguards and security purposes. Three ATR Complex (formerly known as the Reactor Technology Complex [RTC]) casks (designated 306, 701, and XMTR-11) are currently stored above ground in the southwestern portion of CPP-749. Figure 6 shows a plan view of the OFSF, including CPP-749 UGFSF. Figure 7 has a photo of the ops of some of the CPP-749 Generation II Vaults.

A detailed description of the CPP-749 UGFSF is provided in Chapter 2 of the Safety Analysis Report for the Outdoor Fuel Storage Facility [7]. 


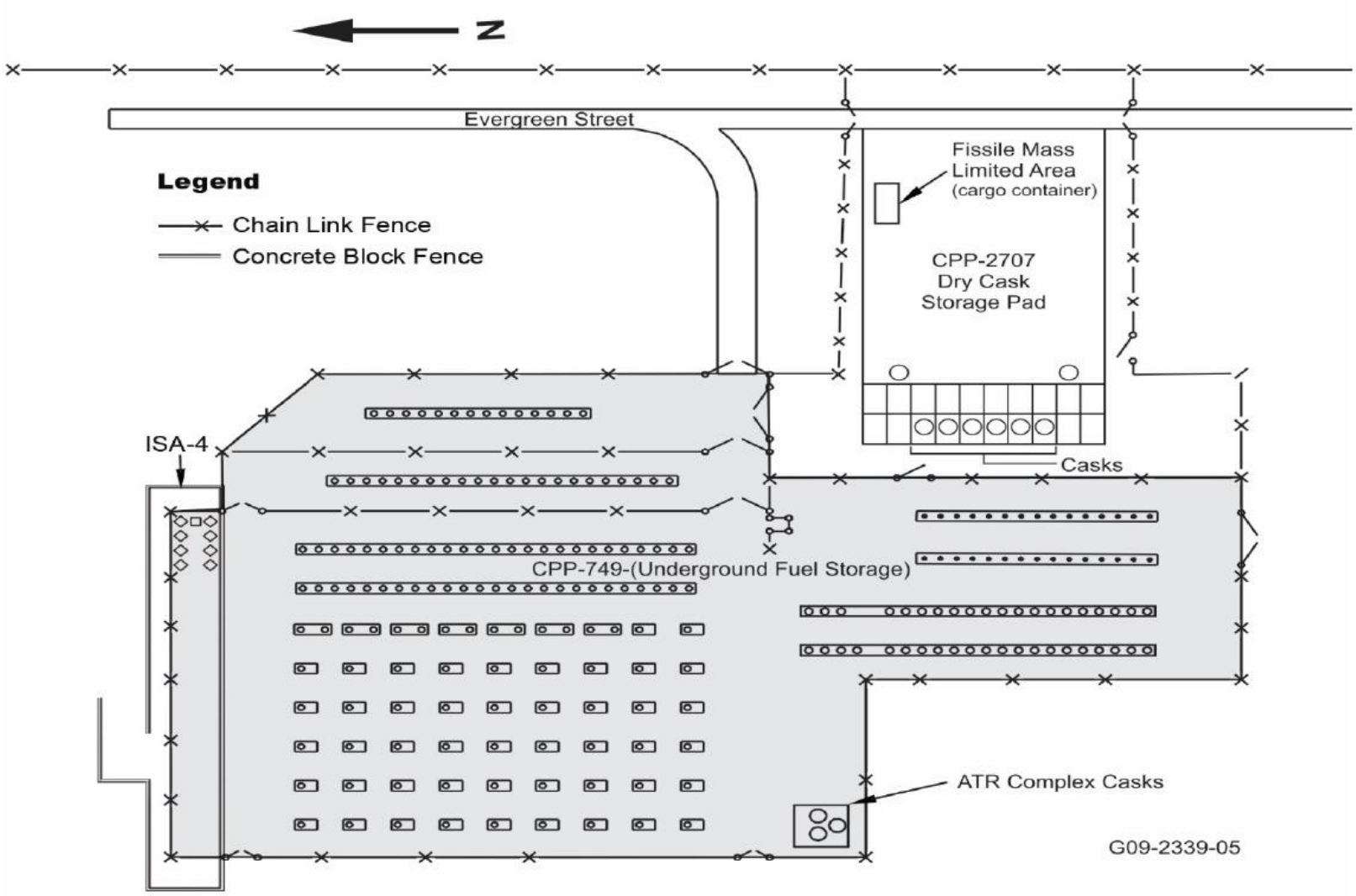

Figure 6. Plan View of Outdoor Fuel Storage Facility (OFSF) (CPP-749 and CPP-2707).

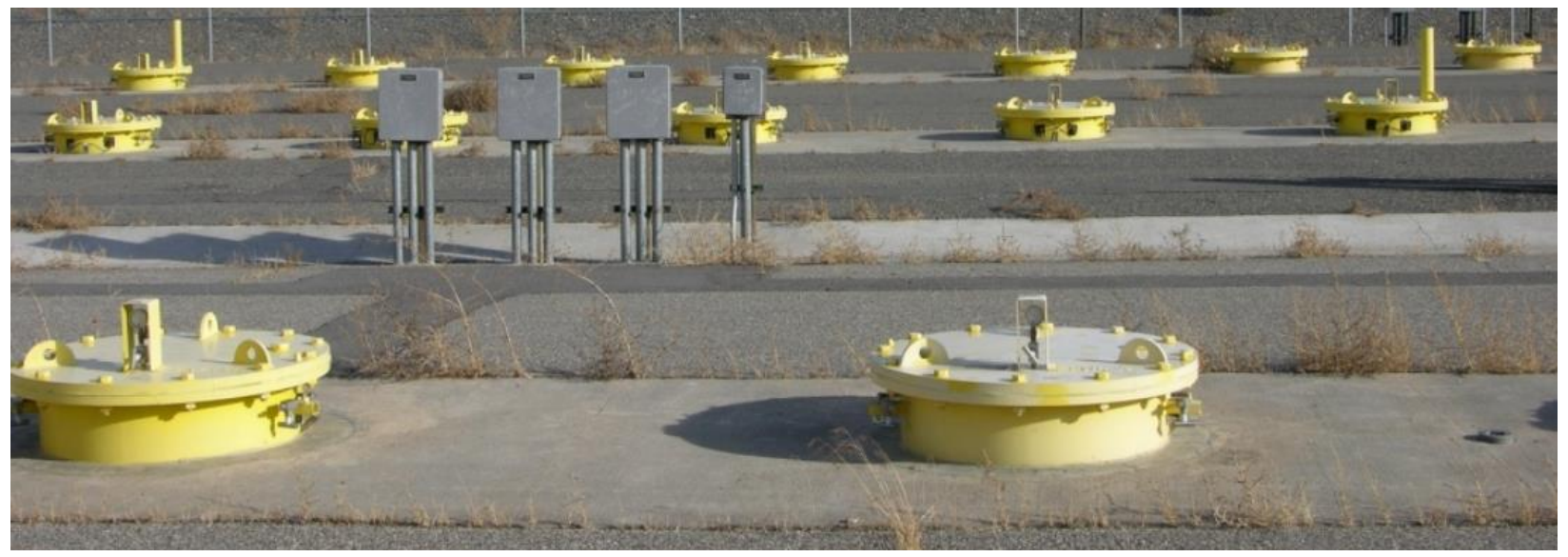

Figure 7. Photo of CPP-749 UGSFS Generation II Vaults.

\subsubsection{CPP-1774 TMI ISFSI}

The CPP-1774 Three Mile Island (TMI) Independent Spent Fuel Storage Installation (ISFSI) is located in the INTEC area of the INL site and is the United States Nuclear Regulatory Commission (NRC) licensed storage facility for containing the high level waste core debris from the TMI Unit 2 (TMI-2) accident.

The CPP-1774 TMI ISFSI consists of high integrity steel Dry Shielded Canister (DSC) inside massive reinforced concrete Horizontal Storage Module (HSM) on a concrete pad surrounded with fences, gates, 
lights, and security measures. The ISFSI layout is based on the use of $30 \mathrm{HSMs}$ (two rows of 15). Each HSM holds one NUHOMS ${ }^{\circledR}-12$ T DSC containing up to 12 TMI-2 canisters. Therefore, 29 HSMs will contain all (344) TMI-2 canisters plus provide four additional TMI-2 canister spaces. An extra HSM serves as a backup in case temporary storage of a DSC is required or in case a challenged canister needs additional confinement. This spare HSM will include a cylindrical overpack so that it can be used as an additional confinement barrier. Figure 8 shows a picture of CPP-1774 TMI ISFSI.

A detailed description of the CPP-1774 TMI ISFSI is provided in Chapter 3 of the Three Mile Island Unit 2 Independent Spent Fuel Storage Installation Safety Analysis Report [8].

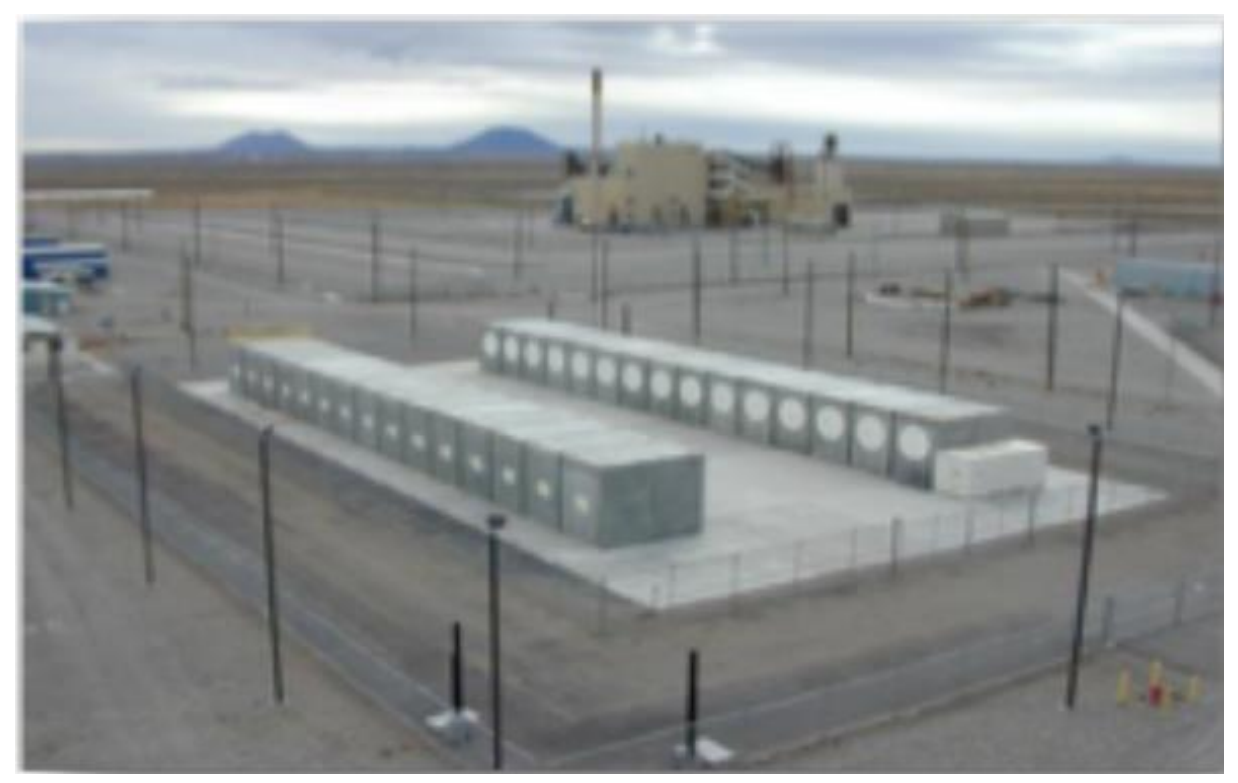

Figure 8. Picture of CPP-1774 with 30 NUHOMS ${ }^{\circledR}-12$ T HSMs on Concrete Pad.

\subsubsection{CPP-2707 Cask Pad Facility}

The CPP-2707 Cask Pad Facility is part of the Outside Fuel Storage Facility (OFSF). The OFSF is designed to provide safe storage of fuel and to provide retrieval capabilities for eventual transfer of the fuel out of the facility. The facility consists of two defined areas, (1) the underground fuel storage portion of the facility where fuel-handling units (FHUs) are stored in underground storage vaults (designated as CPP749) and (2) a concrete pad on which fuel-loaded casks are stored (designated as CPP-2707). In addition to these two defined areas, there are three small ATR Complex casks containing small amounts of fuel located within the CPP-749 area and one fissile material limited area (FMLA) located in a cargo container within CPP-2707.

The CPP-2707 Cask Pad Facility consists of a 6,900- $\mathrm{ft}^{2}$ concrete pad, a 29,250 $\mathrm{ft}^{2}$ asphalt pad apron, and a perimeter fence with gated entry and exit locations (Figure 6). The concrete pad area covers the western portion of the CPP-2707 area and is constructed of a 24 in.-thick compacted backfill covered by 25 in. of gravel covered by an 18-in.-thick reinforced concrete pad. The asphalt pad apron is constructed of a 24 in.-thick compacted backfill covered by 30 in. of gravel covered by a 7-in.-thick asphalt. The westernmost $30-\mathrm{ft}$ by $150-\mathrm{ft}$ area of the asphalt apron is level, while the rest slopes downward at $3 \%$ to the eastern edge. The asphalt apron area is used to accommodate transport vehicles that are capable of handling casks with a maximum weight of 140 tons. This area is used to position transport vehicles to facilitate cask 
placement on the storage pad. Figure 6 shows a plan view of the OFSF, including CPP-2707 Cask Pad. Figure 9 shows six of the eight casks currently on CPP-2707.

The concrete pad area, CPP-2707, is used for storage casks containing SNF. The pad size is sufficient to accommodate 20 cask systems. Currently, eight fuel loaded casks are located on the concrete pad. These include (1) General Nuclear Systems (GNS) Castor V/21; (2) Westinghouse MC-10; (3) Nuclear Packaging, Inc. (NuPac) 125B-2; (4) Ridihalgh, Eggers, and Associates, Inc. (REA)-2023; (5) Transnuclear, Inc. (TN)24P; (6) Pacific Sierra Nuclear Associates, Ventilated Storage Cask (VSC)-17; (7) TN-Robert E. Ginna (REG); and (8) TN-Big Rock Point (BRP) (the last two are not shown in Figure 9). These eight storage cases are on the Contractor Approved Cask List (CACL) [9], which identifies which casks may be stored or handled at CPP-2707. There is also a cargo container used to store small quantities of fissile material located in the CPP-2707 area; this item is denoted as a FMLA.

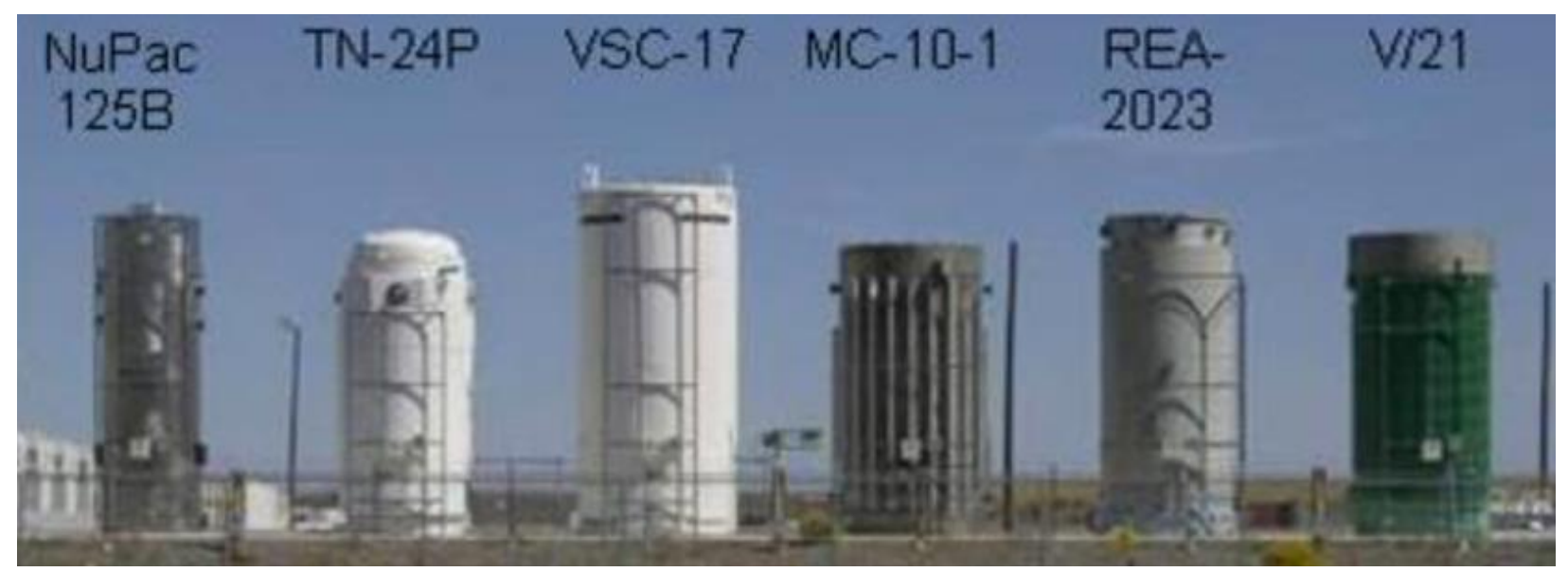

Figure 9. Picture of Six of Eight Casks on CPP-2707 Cask Pad.

A detailed description of the CPP-2707 Cask Pad Facility is provided in Chapter 2 of the Safety Analysis Report for the Outdoor Fuel Storage Facility [7].

\subsubsection{MFC-771 Radioactive Scrap and Waste Facility}

The MFC-771 Radioactive Scrap and Waste Facility (RSWF) is part of the Materials and Fuels Complex (MFC) on the INL site. The MCF-771 RSWF is an outdoor, fenced in limited-access facility approximately 0.5 miles northeast of EBR-II. RSWF was designed to provide interim storage for radioactive material that requires shielding to protect workers from the significant gamma radiation fields associated with the material. RSWF currently provides interim storage for spent nuclear fuel (SNF), accountable material, $\mathrm{RH}$ mixed waste, and various radioactive wastes. SNF includes Experimental Breeder Reactor-II (EBR-II) and other experimental nuclear fuels, in the form of metal, oxides, nitrides, and carbides of uranium, plutonium, or mixed uranium-plutonium. In addition to spent fuel and accountable material, various types of radioactive and mixed waste (e.g., transuranic [TRU], RH low level waste [LLW], mixed RH-TRU) are managed at RSWF.

There are no permanent buildings associated with RSWF. RSWF is 388 -ft-wide and 448 - $\mathrm{ft}$-long outdoor facility surrounded by a security fence which is accessed through one personal gate (associated with the personnel trailer, TR-64) and two vehicle gates. The RSWF is slightly elevated above the surrounding desert for facility drainage. The RSWF stores radioactive materials in below-grade steel liners. The facility contains 27 rows on 12 -ft centers of up to 50 liners on 6 -ft centers, giving a potential total capacity of 1,350 storage locations. The liners are of various diameters. The majority of the RSWF liners are 16-, 24-, and 26-in. OD pipes, but there are some 30-, 48-, and 60-in. OD liners for non-standard 
packages. The liner lengths are $10 \mathrm{ft}, 12 \mathrm{ft} 4 \mathrm{in}, 13 \mathrm{ft} .8 \mathrm{in}$., and $15 \mathrm{ft} 1 \mathrm{in}$. The liners have top plates, and many have shield plugs, and some have bottom fillers (e.g., 6" sand). Figure 10 shows a picture of the RSWF and diagrams of 4 (out of 8) of the different steel liner configurations in the RSWF.

A detailed description of the MFC-771 RSWF is provided in Chapter 2 of the Safety Analysis Report for the Radioactive Scap and Waste Facility (MFC-771) [10].
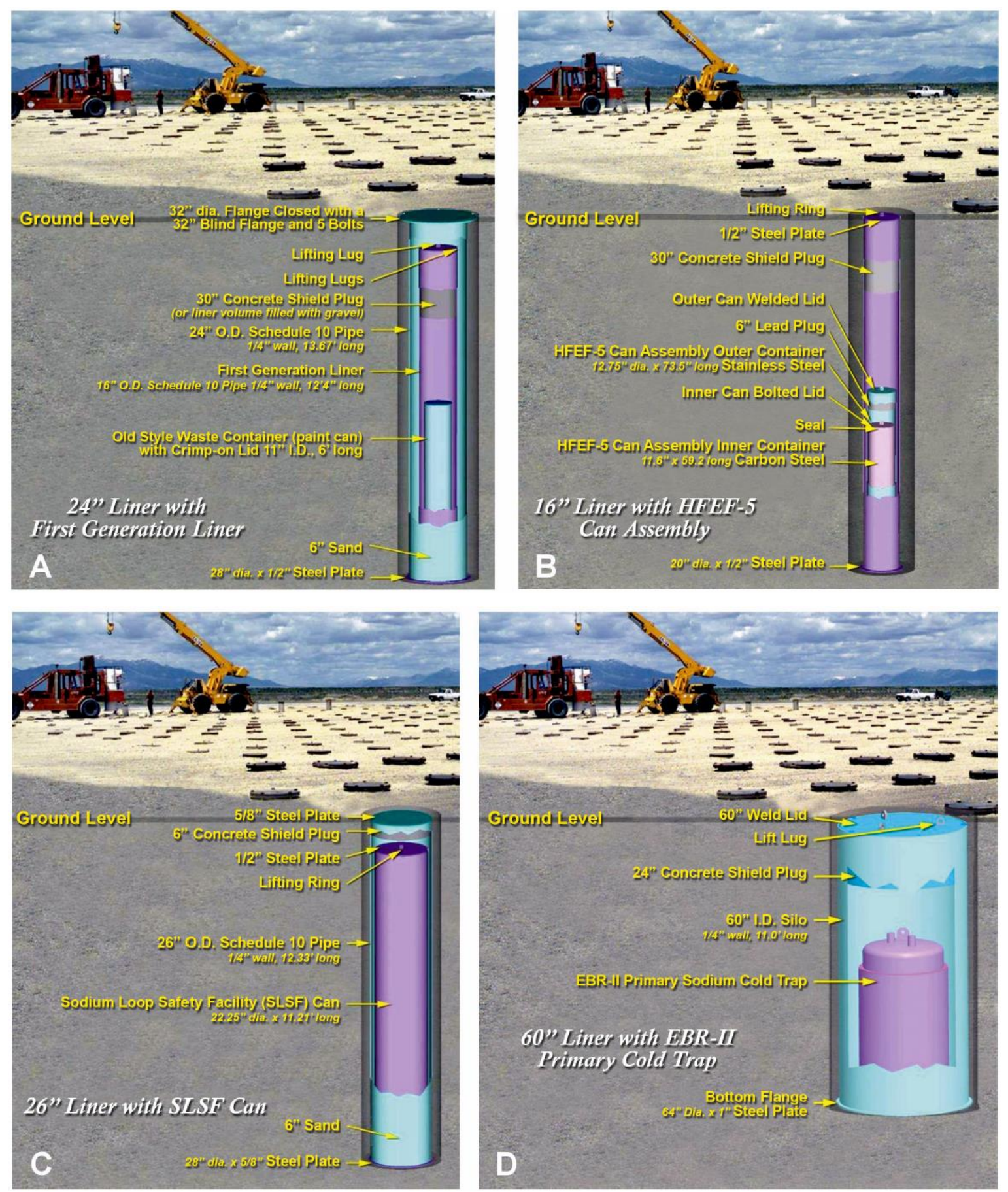

Figure 10. Picture of MFC-771 RSWF Surface with Diagrams of 4 of 8 Types of Liners. 


\subsection{New Facilities}

The following sections describe a new (licensed, but not constructed) facility and some general new facility ideas (neither licensed, nor constructed).

\subsubsection{Idaho Spent Fuel Facility}

The Idaho Spent Fuel Facility (ISFF) or ISF Facility is an ISFSI licensed with the NRC for the INTEC area of the INL site. Although licensed, the ISFF has not been built as of the time of this study.

The ISF Facility consists of three principal areas: 1) the Cask Receipt Area, 2) the Transfer Area, and 3 ) the Storage Area, as shown in Figure 11. For this study, the Storage Area is of greatest interest. The Storage Area consists of a passively cooled concrete vault housing 246 metal storage tubes. Figure 12 shows a cut away view of the Storage Area and shows the handling crane with a transfer cask. Storage tubes are filled with an inert atmosphere to reduce potential corrosion of the ISF canisters during storage. Figure 13 shows a cut-away view of several storage tube assembly loaded with ISF canisters. The design has 216 storage tubes set up for 18" diameter canisters and 30 set up for 24 " diameter canisters.

A detailed description of the ISF Facility is provided in Chapter 4 of Safety Analysis Report (SAR) for the Idaho Spent Fuel (ISF) Facility Independent Spent Fuel Storage Installation (ISFSI) [12].

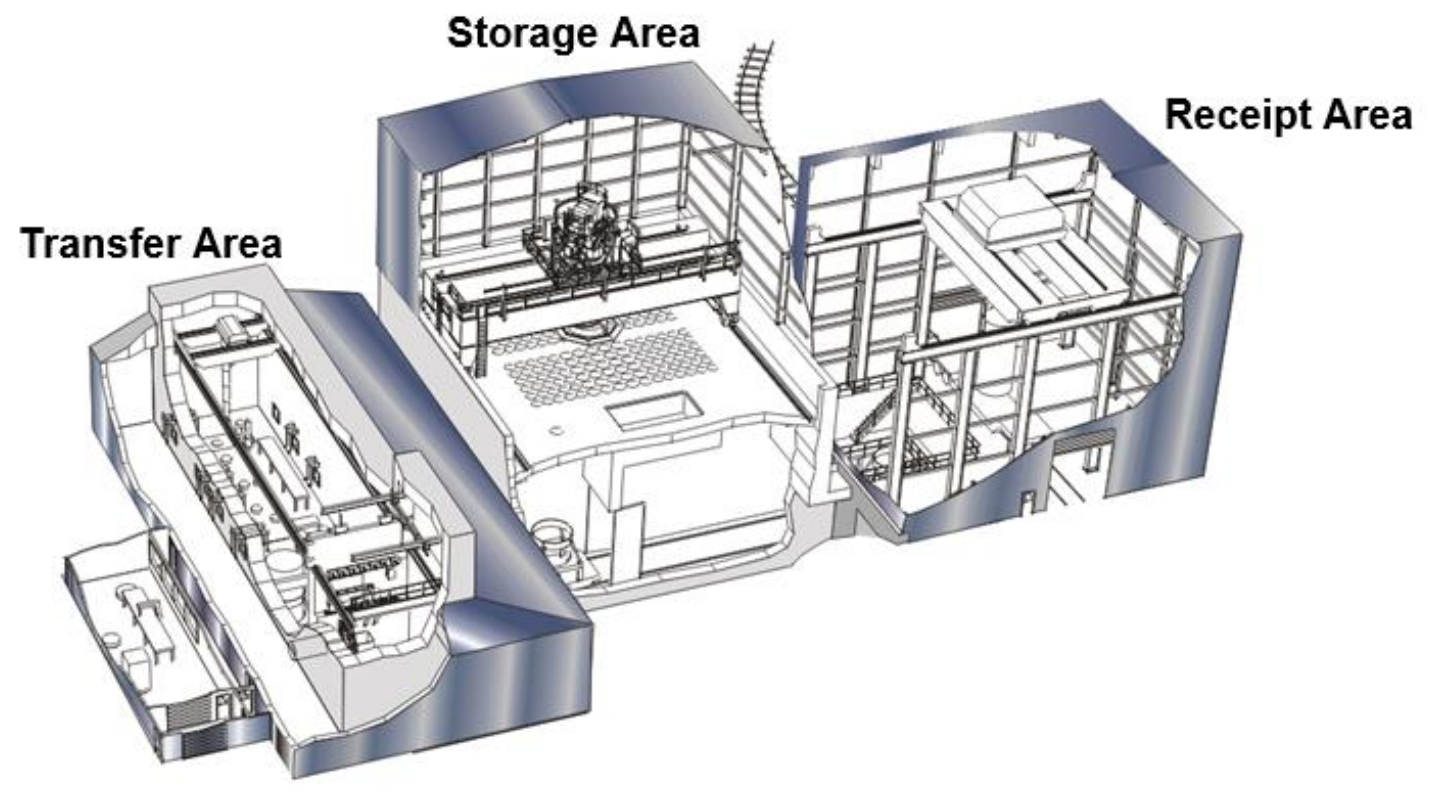

Figure 11. Cut Away View of ISFF Storage Vault Configuration. 


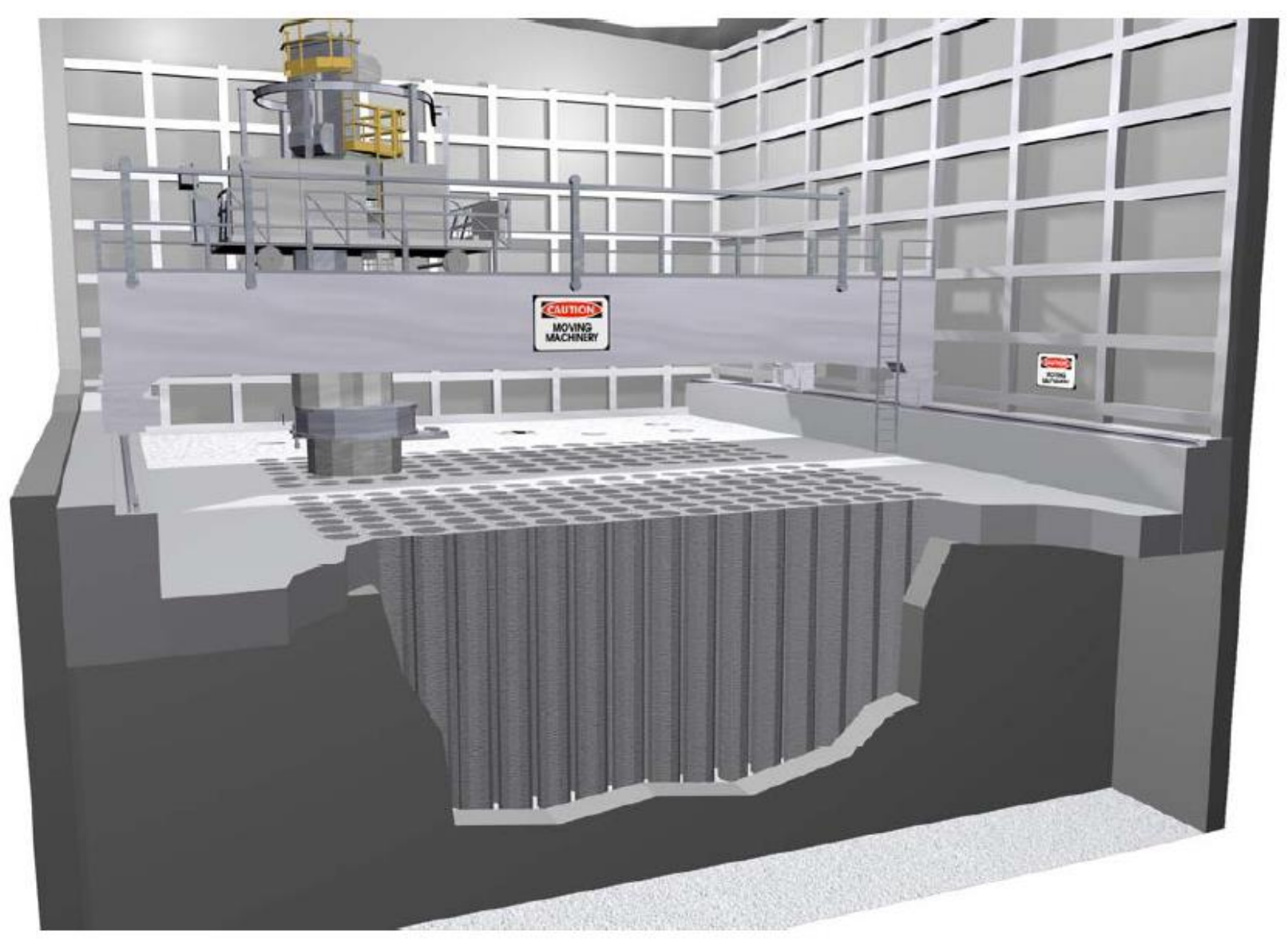

Figure 12. Cut Away View of ISFF Storage Vault Configuration. 


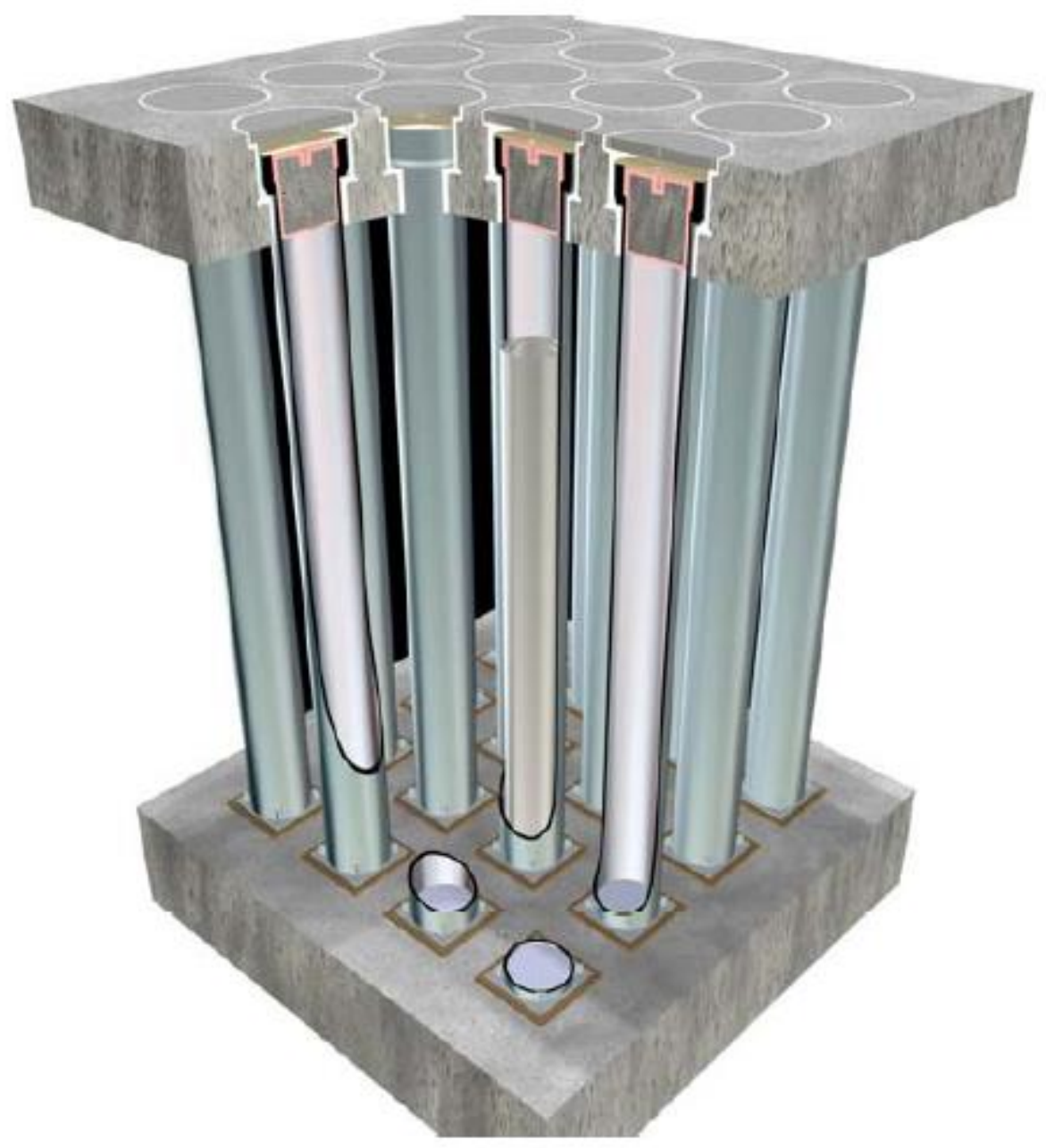

Figure 13. Cut Away View of Loaded ISFF Storage Tube Assemblies.

\subsubsection{Other New Facility Concepts}

The new facility general concept options break down into categories of general location and capacity. Location is broken into above or below grade. Capacity is broken into single canisters, grouping of several canisters, and large arrays of canisters.

Above grade locations utilize man-man materials for shielding. Examples of above grade systems at the INL site are CPP-1774 TMI ISFSI and CPP-2707 Cask Pad. Below grade locations take advantage of shielding and isolation provided by soil/dirt. Examples of below grade systems at the INL site are CPP-749 UFSF and MFC-771 RSWF.

Examples of existing single canister capacity systems at the INL site are CPP-749 UFSF and MFC-771 RSWF. Examples of large array canister systems at (or envisioned for) the INL site are CPP-603 IFSF and ISF Facility. Examples are systems for several canisters are presented in Section 2.4.

As can be noted from the examples, any new facility concepts would mostly be an update/optimized design similar to an existing INL site facility. 


\subsection{New Modular Storage Systems}

The following sections describe new modular storage systems that commercial vendors provided as possible storage solutions for DOE SNF Standardized Canisters. All three vendors noted that these are preliminary suggestions, and that they would need to do detailed walk-downs of the various facilities and operational limitation before they gave more optimized solution suggestions.

\subsubsection{Holtec}

Holtec International (Holtec) suggested HI-STORM (Holtec International STORage Module) FW storage system, and HI-STAR 100 or HI-STAR 100MB storage/transport systems for DOE SNF Standardized Canisters. All three are canister systems that would fit into vertical concrete overpacks for storage or that could be transported once loaded into corresponding transport cask systems. HI-STORM and HI-STAR are entirely modular storage devices; all HI-STAR 100 and HI-STORM FW components are completely compatible. Both HI-STAR 100 and HI-STORM FW Systems have common attributes which make them ideal for multi-purpose canister (MPC) systems. All these systems are NRC licensed, and could have amendments to allow them to store and transport DOE SNF Standardized Canisters.

Based on initial assessments, the different Holtec systems could easily accommodate DOE SNF Standardized Canisters. The number of DOE SNF Standardized Canisters each system could be loaded with is listed in Table 1.

Table 1. Number of DOE SNF Standardized Canisters in Different Holtec Systems.

\begin{tabular}{|c|c|c|c|}
\hline Canister & HI-STORM FW & HI-STAR 100 & HI-STAR100MB \\
\hline Small-Short (18'x10') & 7 & 7 & 7 \\
\hline Small-Long (18'x15') & 7 & 7 & 7 \\
\hline Large-Short (24"x10') & 5 & 5 & 5 \\
\hline Large-Long (24"x15') & 5 & 5 & 5 \\
\hline
\end{tabular}

\subsubsection{HI-STORM}

HI-STORM is strictly a storage device, albeit an extremely rugged and robust one. Conceptualized in 1993, HI-STORM is a vertical ventilated system that promotes passive air cooling of the stored canister and is engineered for maximum shielding. With an all-structural steel skeleton and twenty-six inches of concrete enclosed in the annular space between two concentric ductile metallic shells, HI-STORM 100 embodies the best attributes of metal and concrete. HI-STORM is available in multiple models. They are:

- Above-ground, Free-standing

- Above-ground, Anchored

- Below Ground

All model configurations hold the canister in a vertical configuration that minimizes skyshine and facilitates convenient installation or removal of the canister.

The CoC and SER for the HI-STORM 100 System under 10CFR Part 72 were issued on May 1, 2000 with the effective date of May 31, 2000. Figure 14 has a picture of a HI-STORM FW on a ISFSI.

The loading of fuel into HI-STORM 100s MPC at utilities uses a transfer cask, the HI-TRAC (ㅁoltec

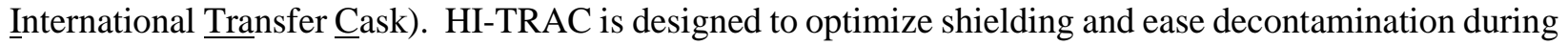
loading and unloading operations. Figure 15 has a picture of a HI-TRAC. 


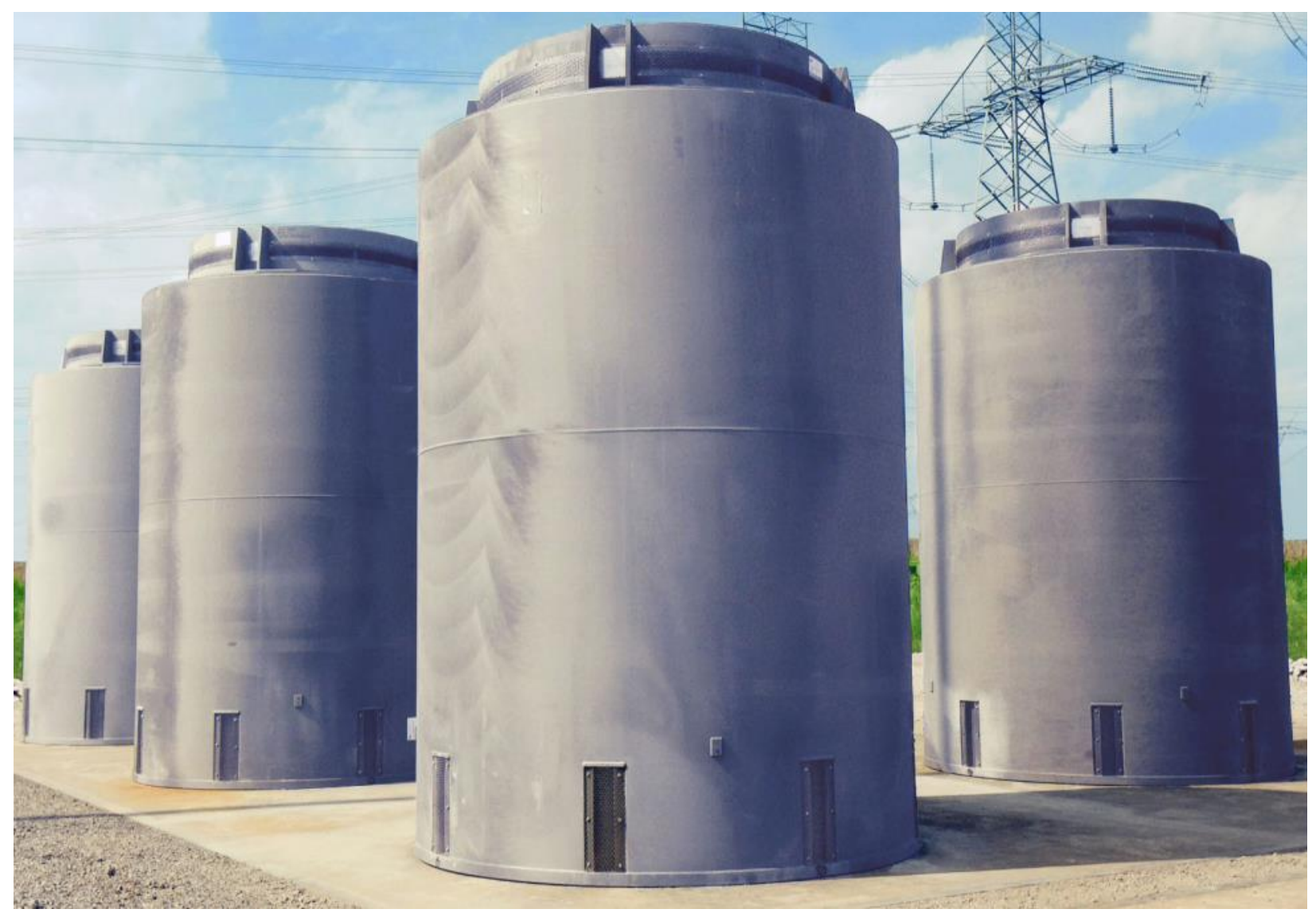

Figure 14. HI-STORM FW on ISFSI.

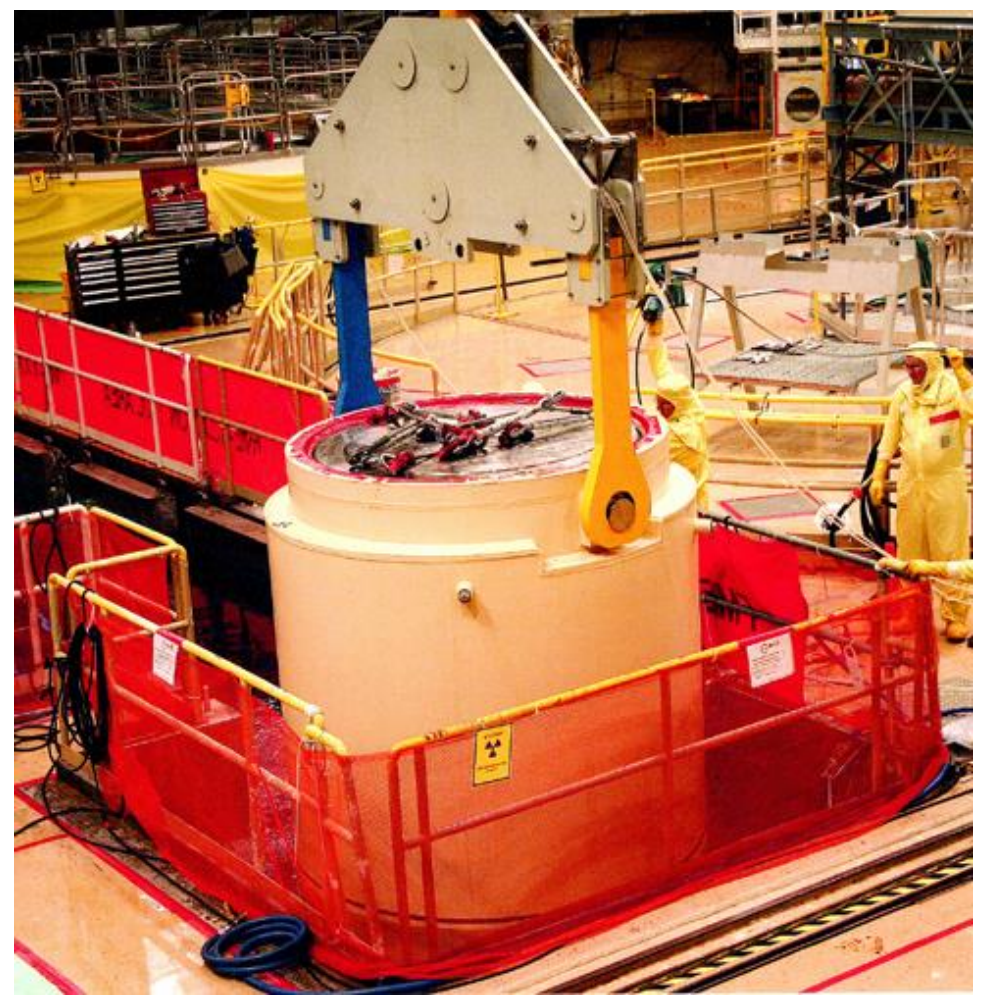

Figure 15. HI-TRAC. 


\subsubsection{HI-STAR}

HI-STAR (Holtec International Storage Transport And Repository) 100 was conceived in 1992 and is the nuclear industry's first high-capacity, MPC technology-based system which is equally proficient at storing the spent nuclear fuel on an ISFSI pad, or at transporting its highly radioactive payload over land or water. HI-STAR 100 is engineered to accept one multi-purpose canister.

In 1999, Holtec International received a CoC under 10CFR Part 71 (transport) for our MPC technologybased HI-STAR 100 System and under 10CFR Part 72 (storage), giving the nuclear industry its first certified dual-purpose system with MPC technology.

Figure 16 has a photo of four HI-STAR 100s on a pad. Figure 17 has an illustration of a HI-STAR $100 \mathrm{MB}$ on a rail car in a typical transport configuration. Figure 18 shows HI-STORM 100s and HI-STAR 100s side by side on a concrete pad.

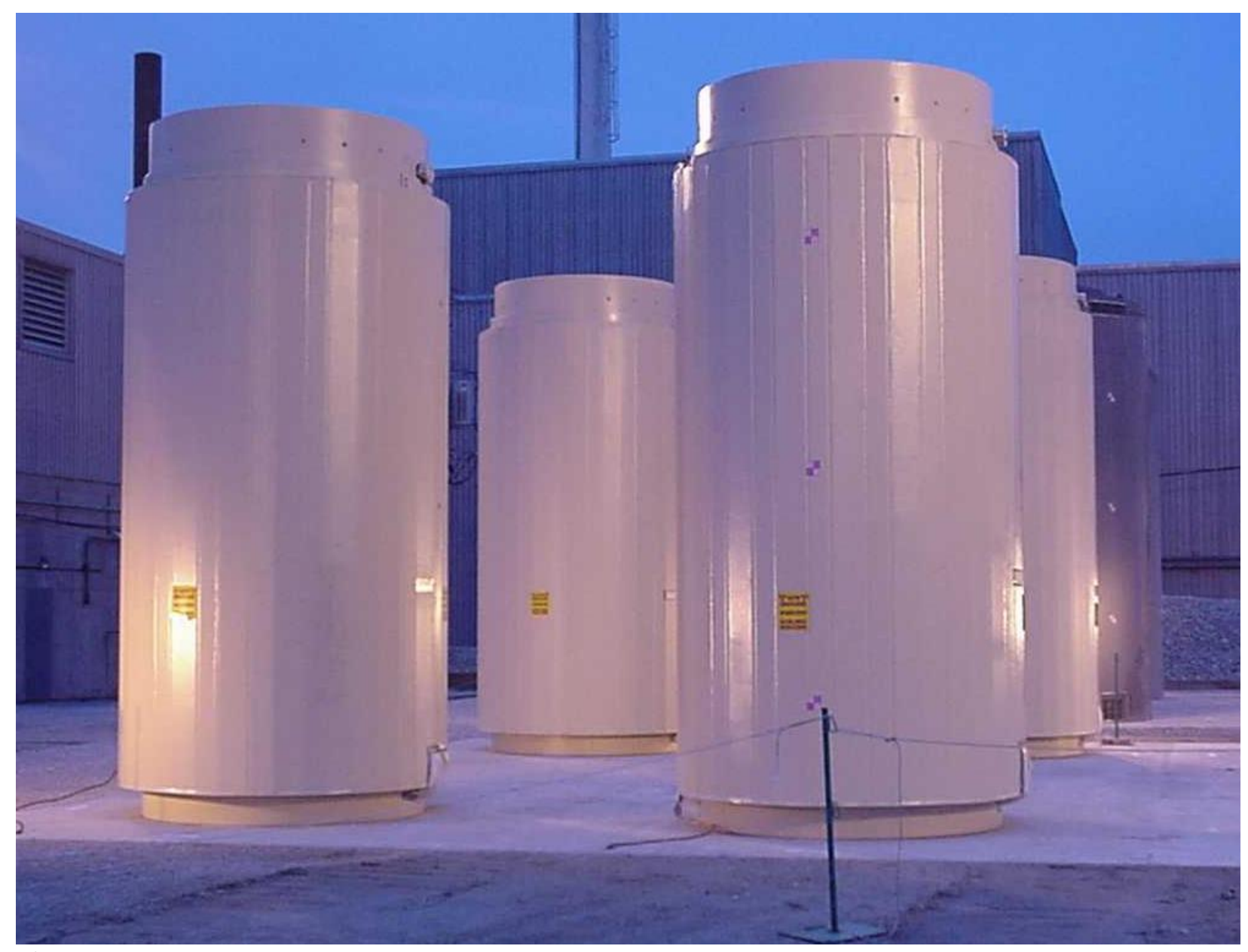

Figure 16. HI-STAR 100. 


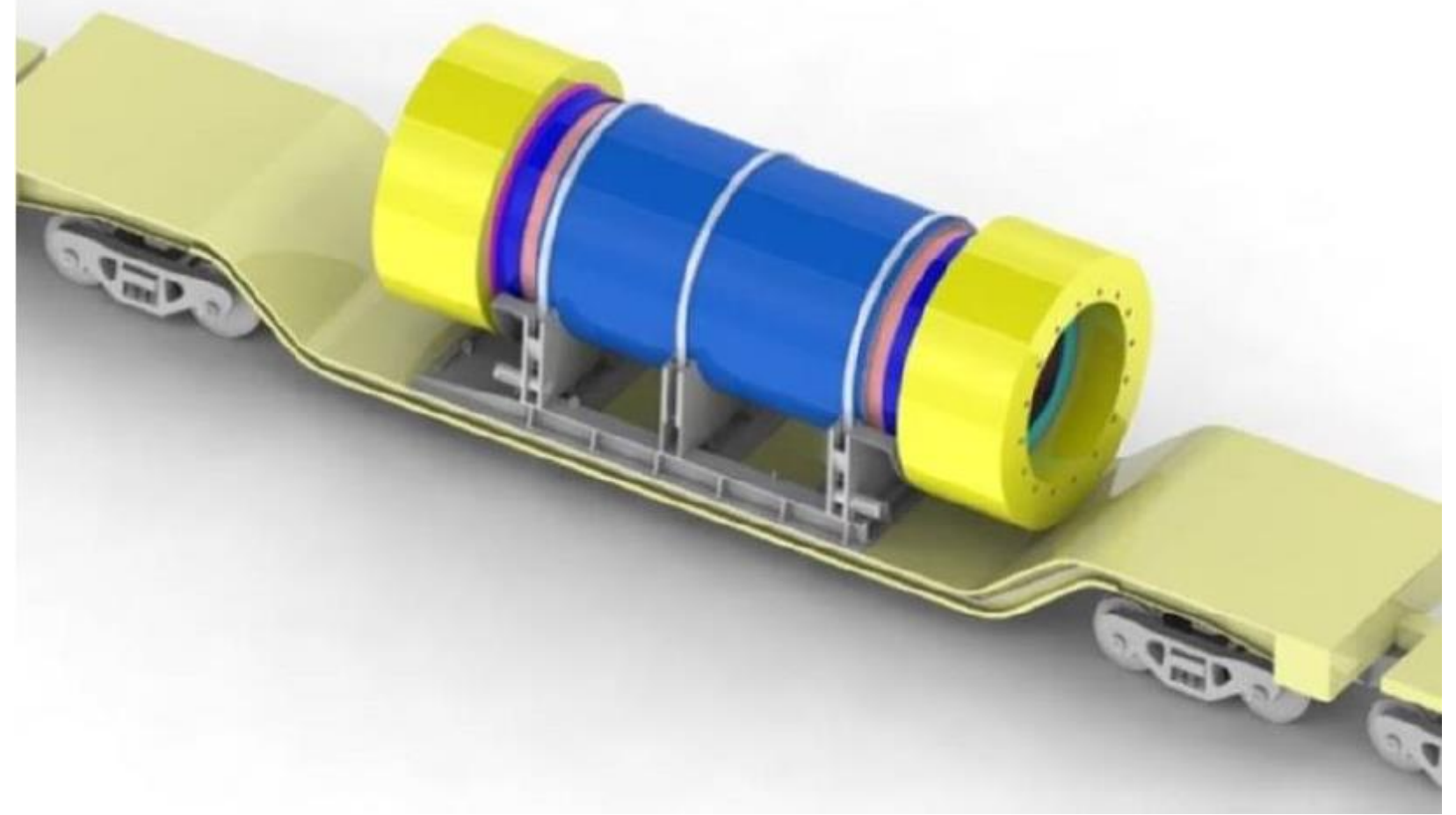

Figure 17. Illustration of a HI-STAR 100MB on a Rail Car.

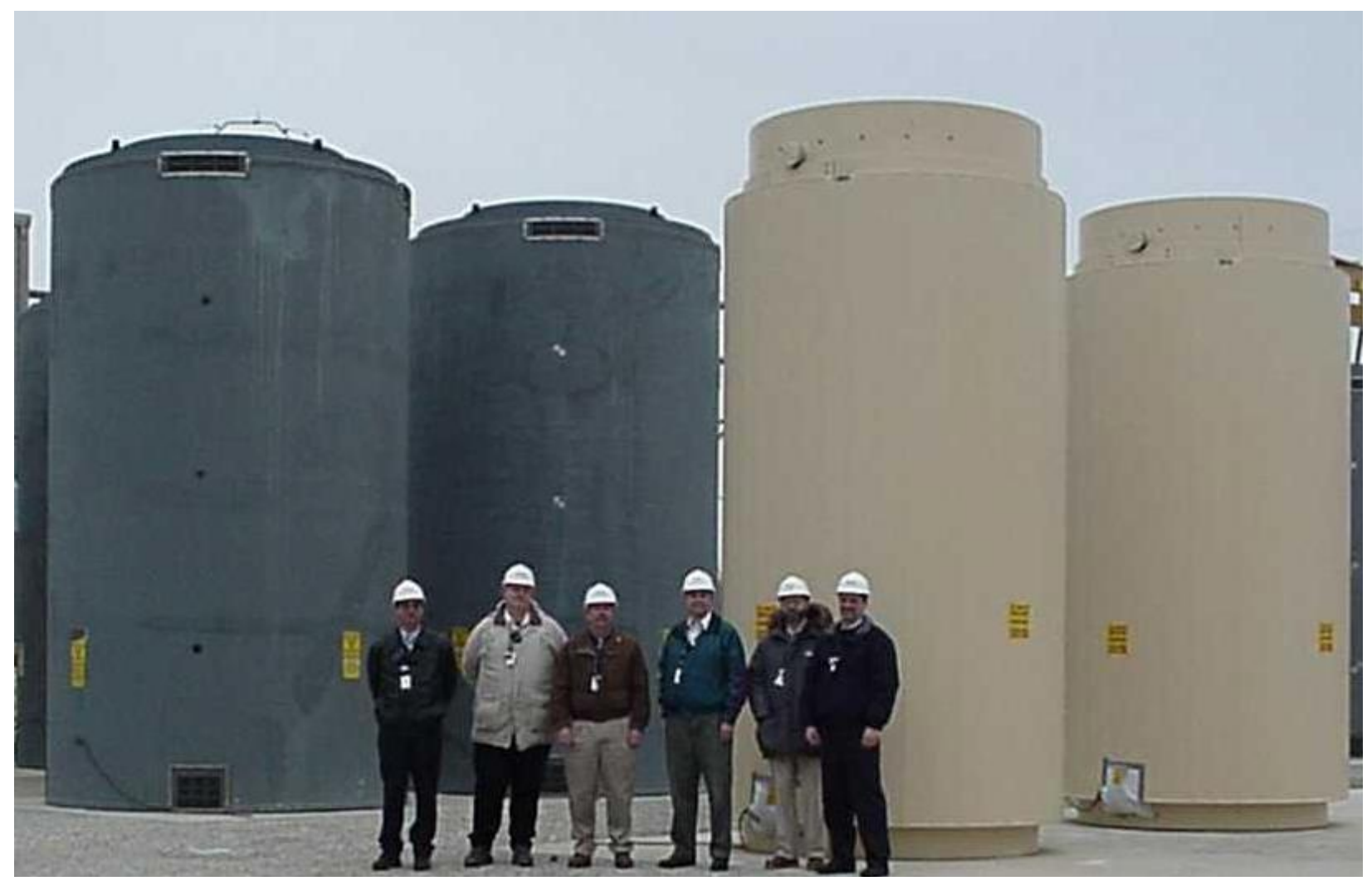

Figure 18. HI-STORM 100 (dark grey colored, left) and HI-STAR 100 (sand colored, right). 


\subsubsection{Holtec Storage Locations}

The Holtec HI-STORM and HI-STAR system can be stored in several different arrangements. Figure 19 shows them: a) on a traditional concrete pad (like CPP-2707), b) in underground vaults (HI-STORM UMAX, similar to CPP-749), and c) in a buttress building.

a)

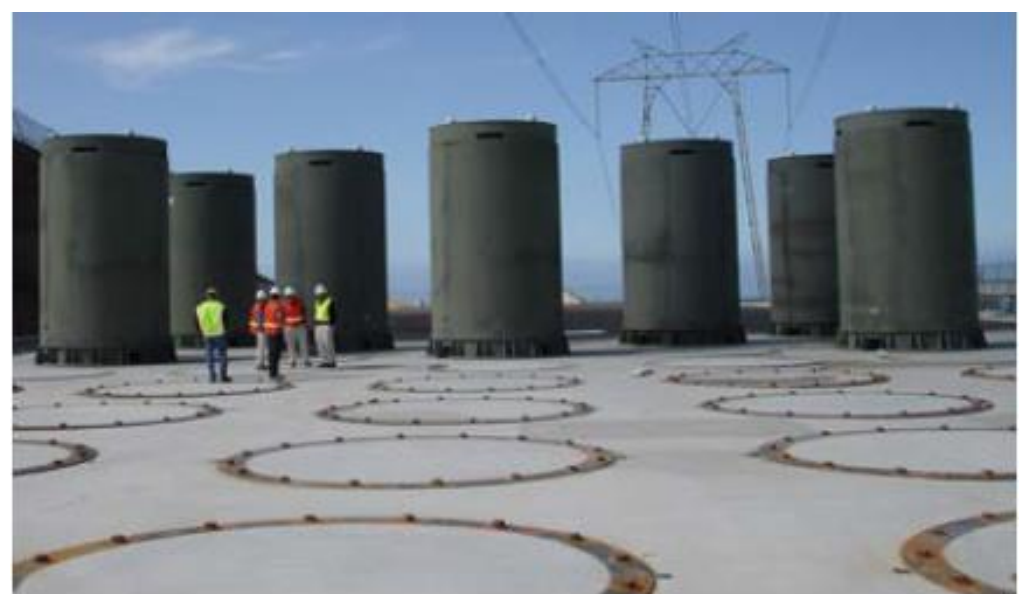

b)

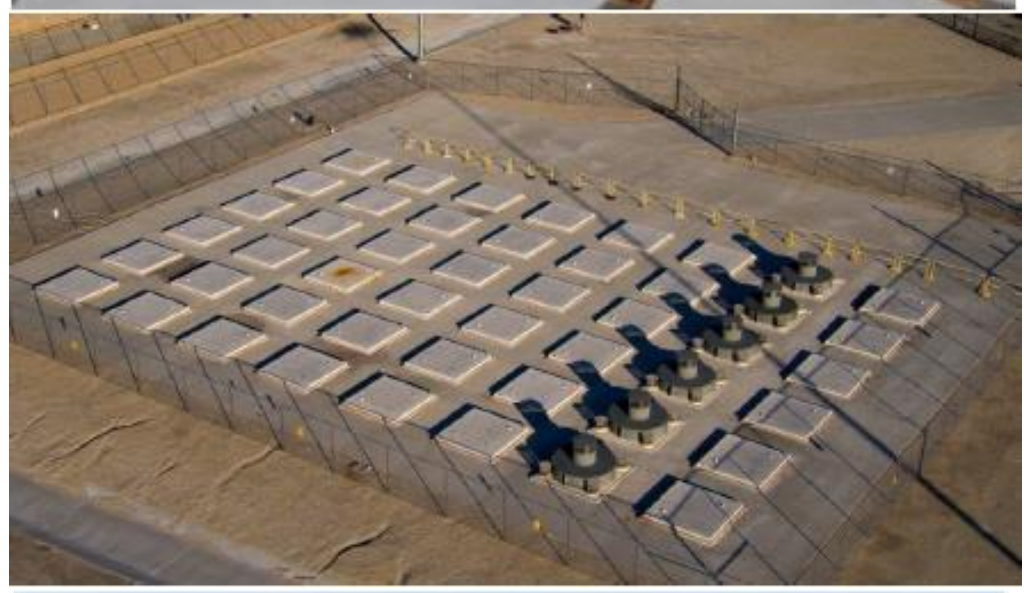

c)

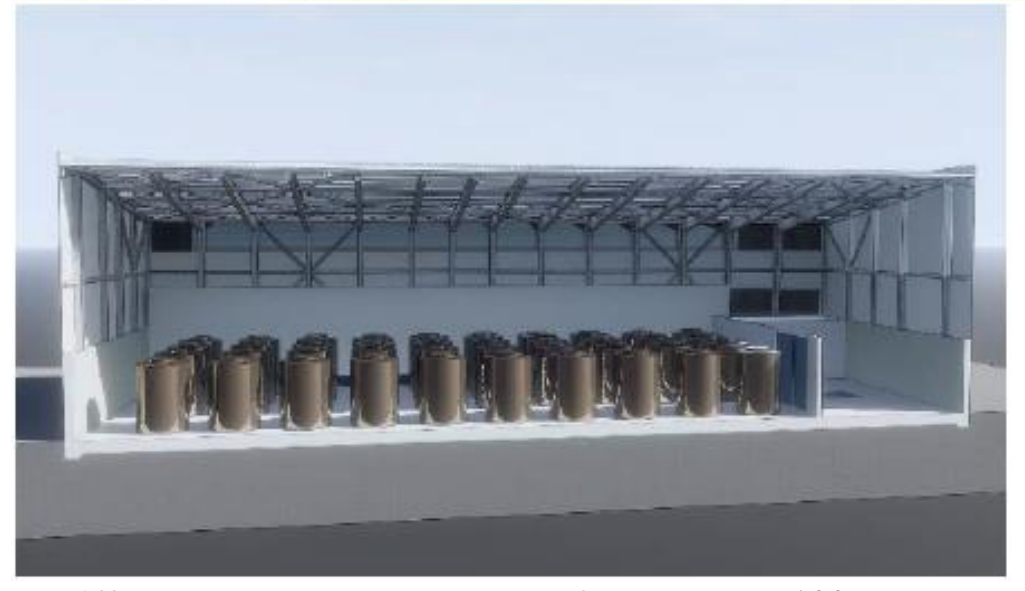

Figure 19. Different Storage Arrangements of HI-STORM 100's. 


\subsubsection{Holtec's Consolidated Interim Storage Facility HI-STORE}

Holtec is currently working to obtain an NRC license for a Consolidated Interim Storage Facility (CISF) in New Mexico where SNF storage casks could be stored until a repository is opened. The NRC review could be completed in 2020, and operation could commence by 2023 . The license is for an initial storage capacity of $500 \mathrm{HI}-\mathrm{STORM}$ canisters of commercial SNF (( 8,680 MTU). The storage capacity of the site in 10,000 canisters. It is expected that the HI-STORE license could be amended for DOE-owned SNF to be stored in a separate area (with any additional security measures). Figure 20 shows an illustration with parts of the HI-STORE CISF. Figure 21 shows an illustration of the HI-STORE HI-STORM UMAX for the initial $500 \mathrm{HI}-\mathrm{STORM}$ canister capacity.

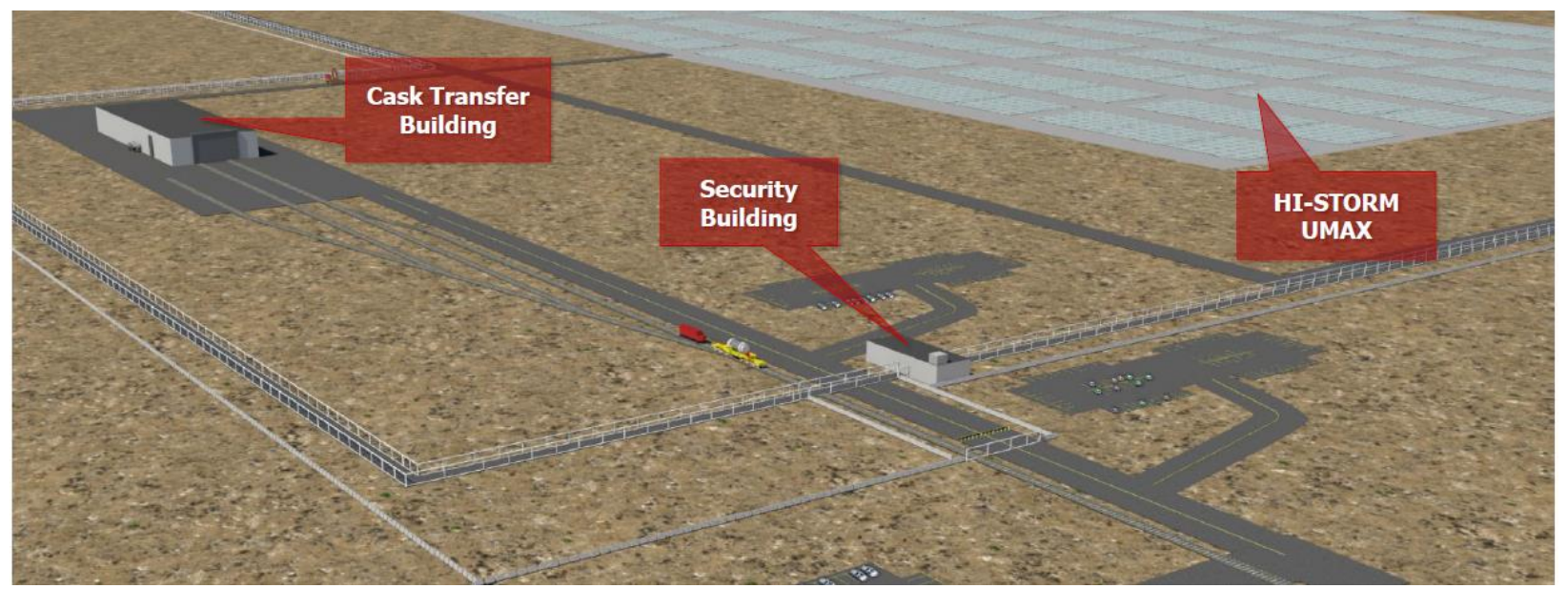

Figure 20. Illustration of HI-STORE CISF.

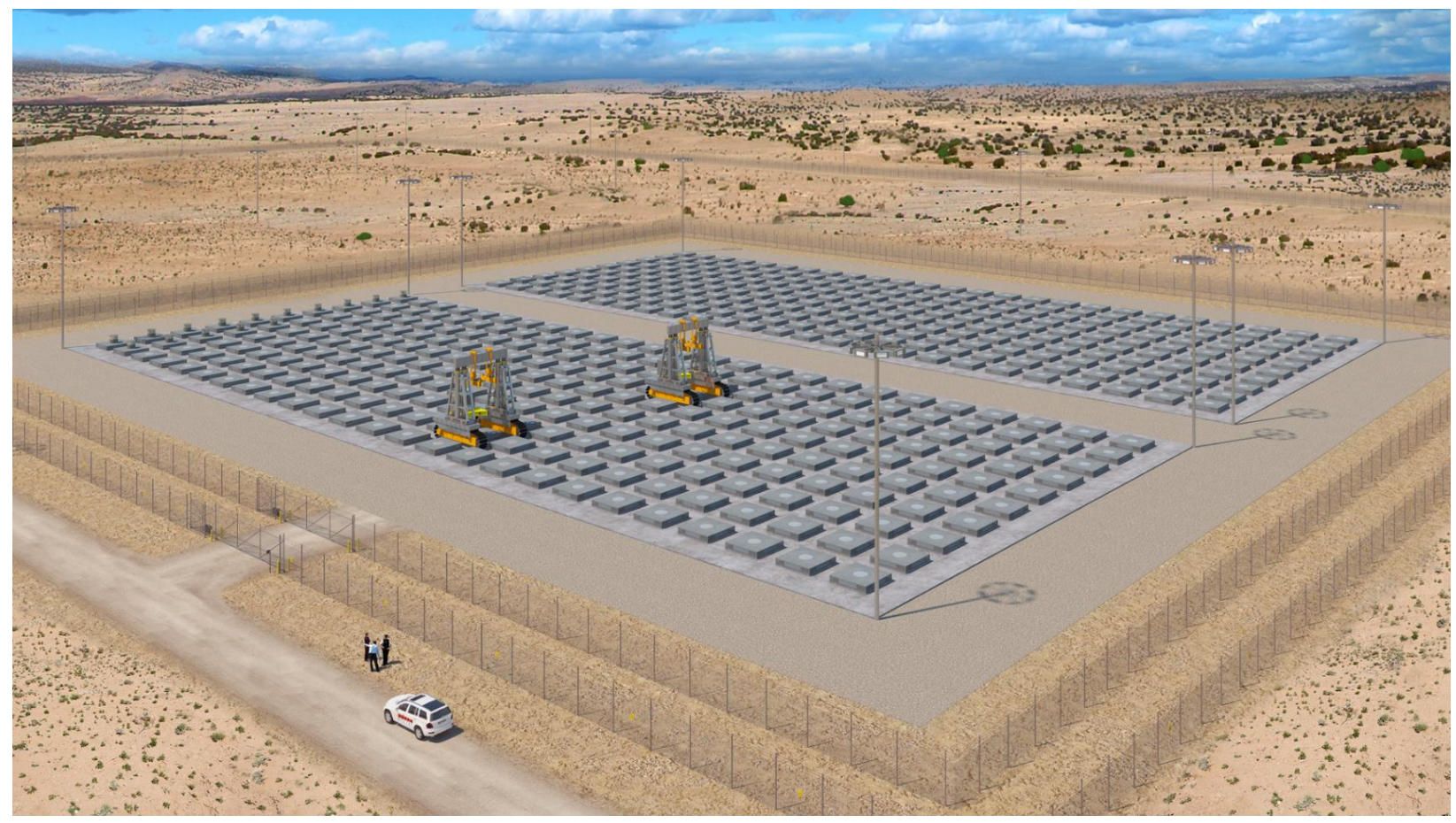

Figure 21. Illustration of HI-STORE's HI-STORM UMAX. 


\subsubsection{NAC}

NAC International (NAC) suggested three possible dry storage configurations for storage of loaded DOE SNF Standardized Canisters: NAC-MPC (Multi-Purpose Canister) system, NAC-UMS ${ }^{\mathrm{TM}}$ (Universal Multipurpose System) system, and MAGNASTOR. All three are modular canister systems that would fit into vertical concrete overpacks for storage or into a transport cask system for transport. All these systems are NRC licensed, and could have amendments to allow them to store and transport DOE SNF Standardized Canisters.

Based on initial assessments, the different NAC systems could easily accommodate DOE SNF Standardized Canisters. The number of DOE SNF Standardized Canisters each system could be loaded with is listed in Table 2.

Table 2. Number of DOE SNF Standardized Canisters in Different NAC Systems.

\begin{tabular}{|c|c|c|c|}
\hline Canister & NAC-UMS & NAC-MPC & MAGNASTOR \\
\hline Small-Short (18'x10') & 9 & 9 & 9 \\
\hline Small-Long (18'x15') & 9 & 9 & 9 \\
\hline Large-Short (24"x10') & $4-5$ & $5-7$ & 7 \\
\hline Large-Long (24"x15') & $4-5$ & $5-7$ & 7 \\
\hline
\end{tabular}

Note: Assumptions regarding cell opening, tolerances and clearances may be limiting factors to achieving optimized loading system capacity. For example, at West Valley, the cell opening for each 24-inch canister was approximately 25+/- 0.1 inches to accommodate minor canister circumferential distortions, bowing, etc. Of related importance, minor modifications to canister system could be made to address these requirements.

\subsubsection{NAC-MPC}

The NAC-MPC is a canister system that is transport-ready with the NAC-STC. The NAC-MPC was specially designed for the management of spent nuclear fuel at older commercial plants, but has been modified, analysed and approved for challenging non-fuel nuclear wastes at government sites (radioactive capsules for the Waste Encapsulation and Storage Facility at the DOE Hanford Site in Washington State, and canisters of vitrified high-level waste glass at DOE's West Valley Demonstration Project (WVDP) in New York).

A transfer cask will move the transportable storage canister from loading location to the vertical concrete cask for storage, where it remains in the vertical concrete cask until it is transferred to the universal transport cask overpack at the time of shipment off-site.

Figure 23 shows an illustration of a dry storage canister and the Dry Transfer System on top of a NACMPC. Figure 24 shows a NAC-MPC for West Valley and a picture of the cask movement to the Storage Pad. Figure 25 shows a picture of a NAC-STC loaded with an MPC at WVDP. 

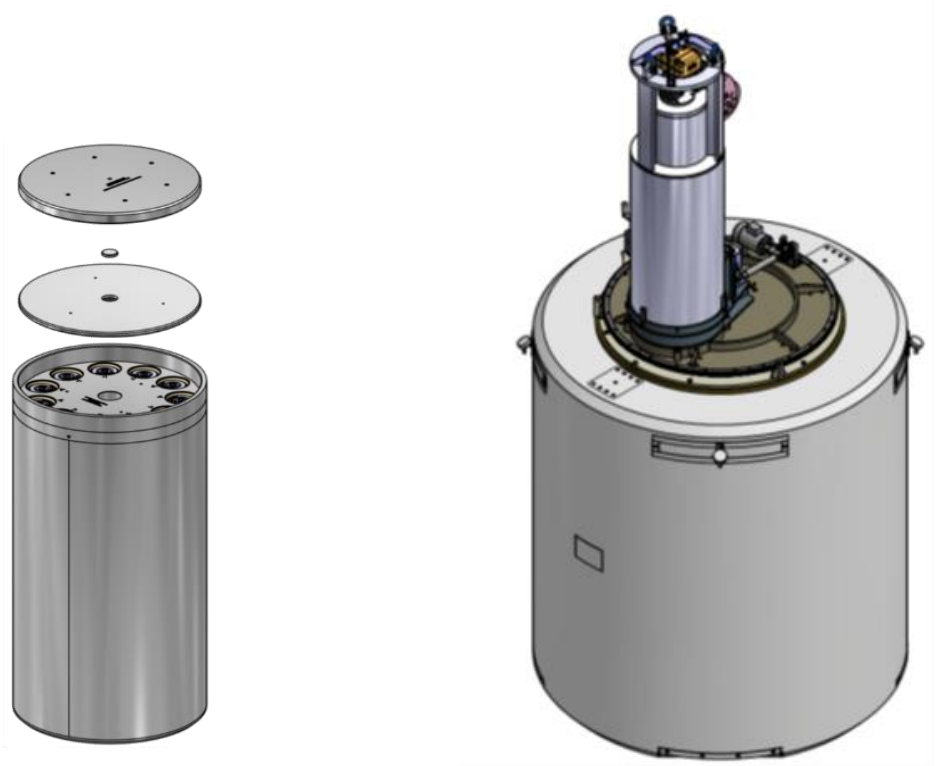

Figure 23. Dry Storage Canisters (Left), Dry Transfer System and NAC-MPC (Right).
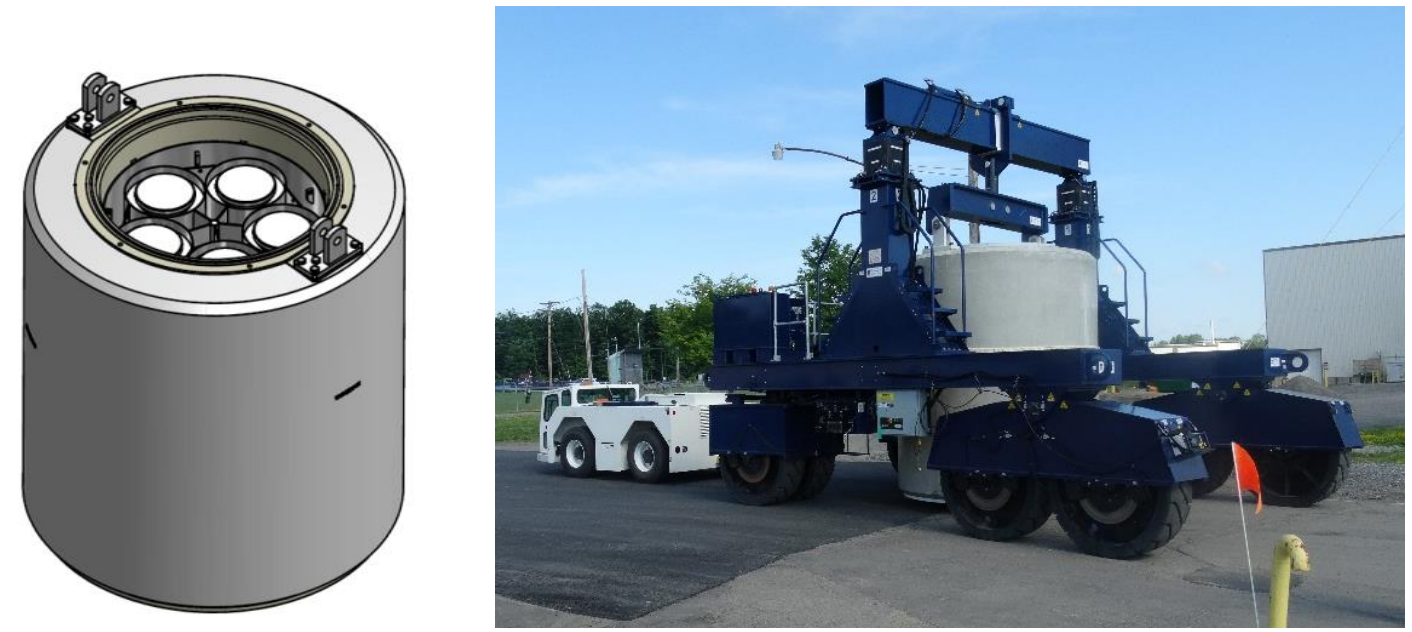

Figure 24. NAC-MPC for WVDP (Left). Cask Movement to the Storage Pad (Right). 


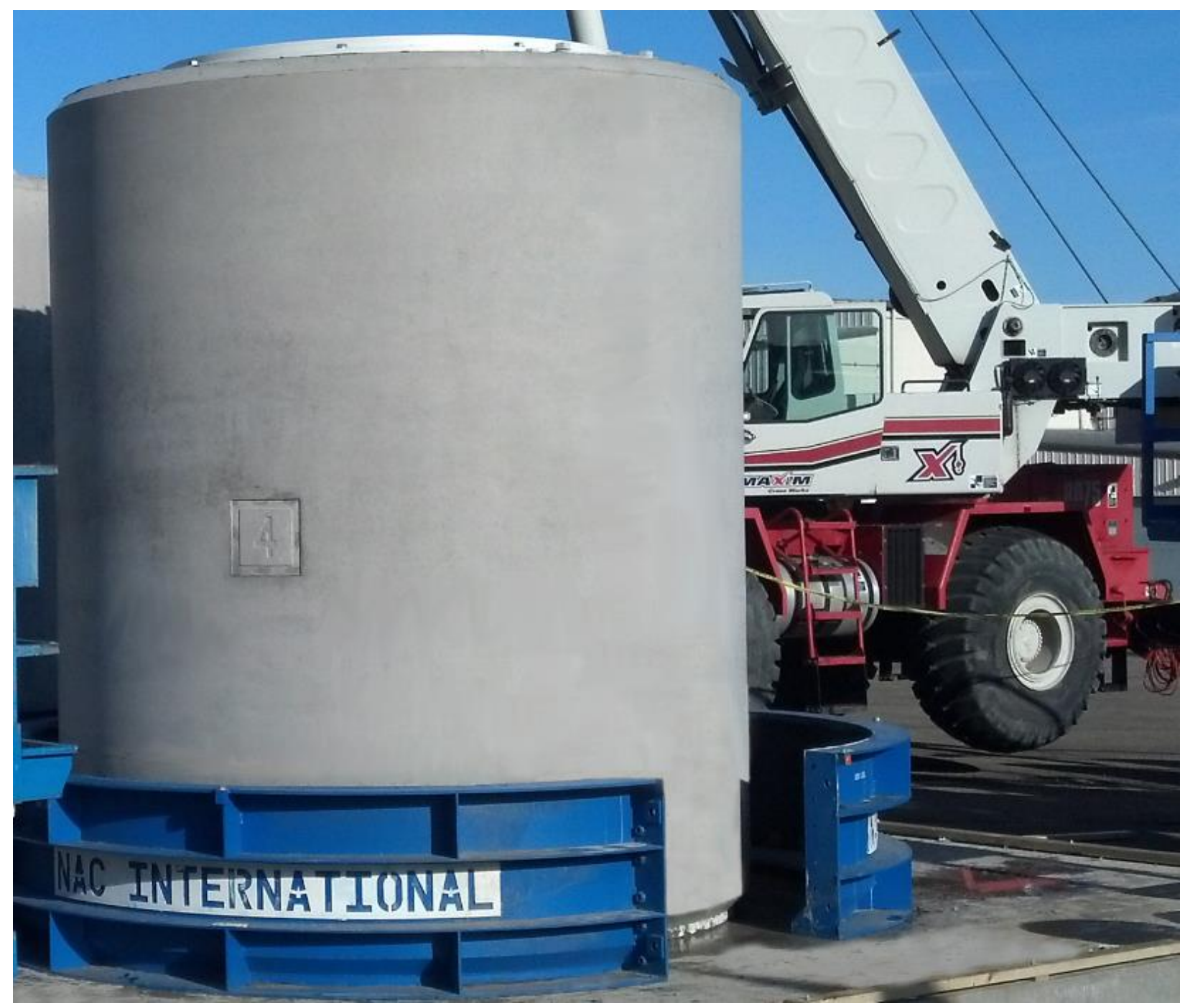

Figure 25. NAC-MPC located at WVDP.

\subsubsection{NAC-UMS}

The NAC-UMS system is an evolutionary design based on the earlier-licensed NAC-STC basket and transport overpack designs. The UMS was engineered to simply provide an excellent and safe system for storing and transporting nuclear fuel. The UMS has four primary components:

- Transportable storage canister

- Vertical concrete cask storage overpack

- Universal transport cask overpack

- Auxiliary equipment, including the transfer cask.

Figure 26 shows a picture of NAC-UMS casks on a concrete pad and includes a view of the yellow cask site transporter. 


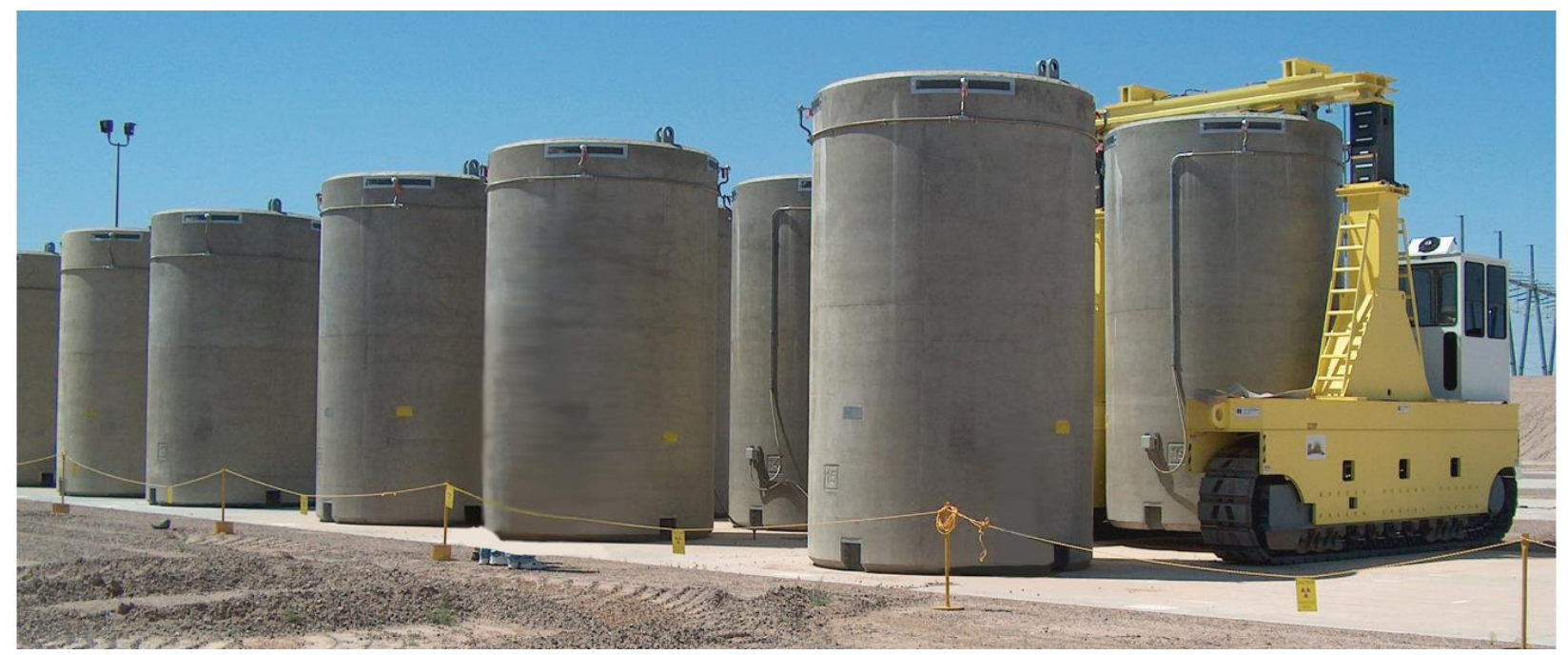

Figure 26. NAC-UMS Casks located at Palo Verde Nuclear Power Plant.

\subsubsection{MAGNASTOR}

MAGNASTOR $^{\circledR}$ (Modular, Advanced Generation, Nuclear All-purpose STORage System) is NAC’s new generation dry storage system. Figure 27 shows a picture of the MAGNASTOR system.

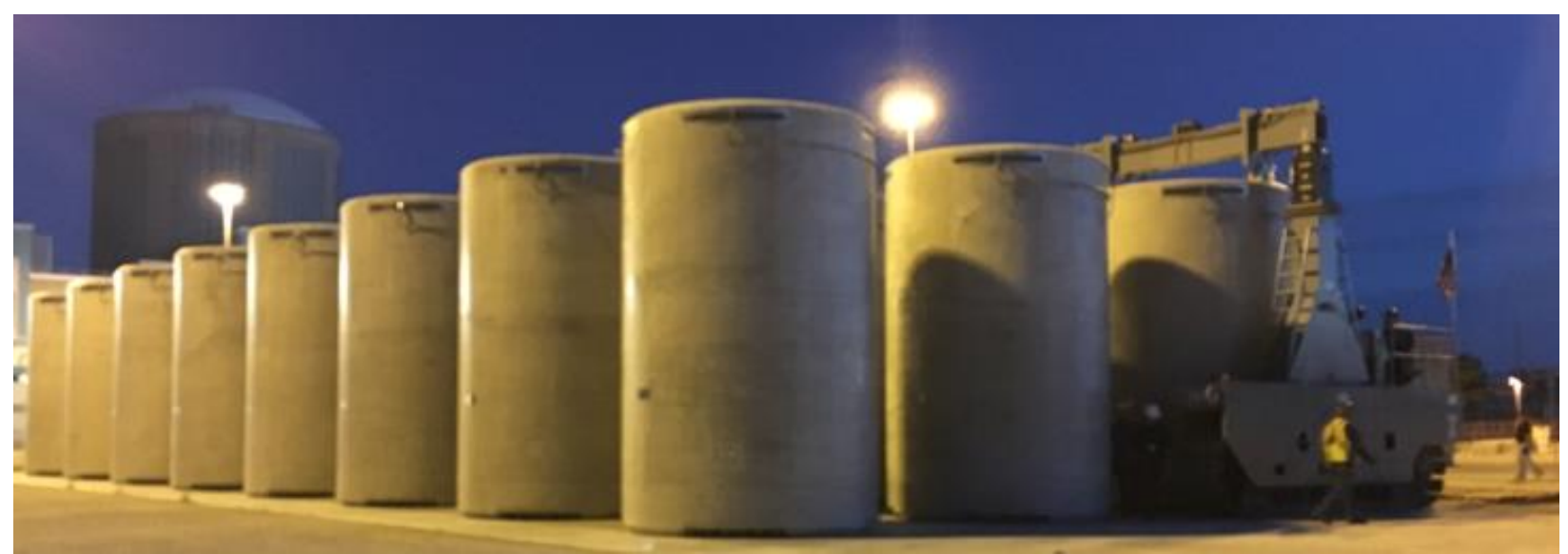

Figure 27. MAGNASTOR Casks located at Kewaunee Nuclear Power Plant.

\subsubsection{Transportation Casks/Overpacks}

The loaded MPCs associated with the three NAC storage systems can be transported once loaded into corresponding transport cask systems: NAC-STC, NAC-UMST, and MAGNATRAN. These transport cask systems are NRC licensed. Figure 28 shows a picture of a NAC-STC containing a NAC-MPC canister. 


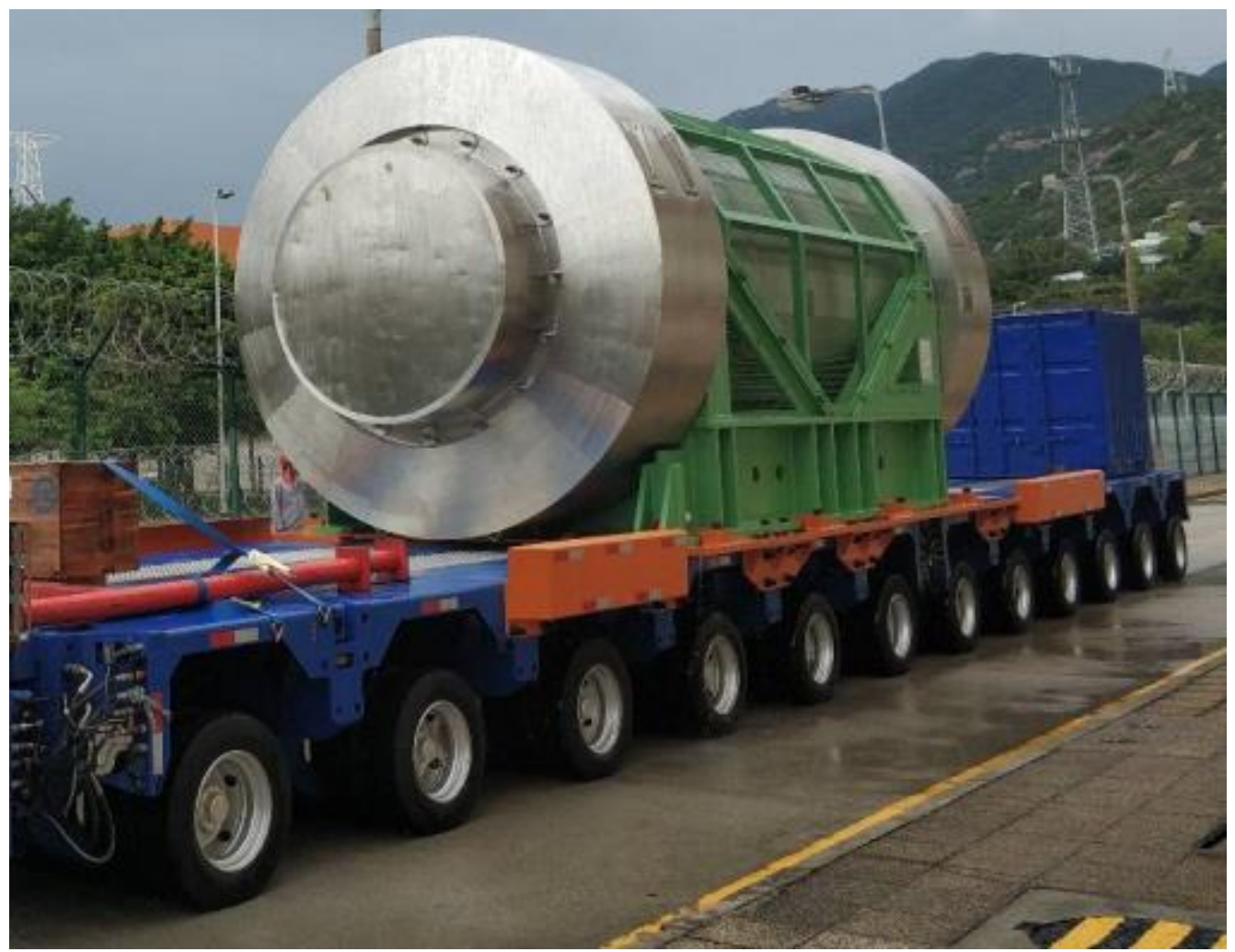

Figure 28. NAC-STC (Containing and NAC MPC) located at Daya Bay Nuclear Power Plant.

\subsubsection{NAC Storage Locations}

The NAC storage system are stored on a traditional concrete pad (like CPP-2707, which currently has storage casks stored on it).

\subsubsection{Waste Control Specialists CISF}

Waste Control Specialists (WCS), with partners Orano USA and NAC International, have submitted an application to the NRC for a license to construct and operate a CISF for used nuclear fuel in west Texas. Similar to the Holtec system, this CISF is being licensed for commercial SNF. It is expected that the license could be amended for DOE-owned SNF to be stored in a separate area (with any additional security measures). Figure 29 has an illustration of NAC MPCs on a CISF concrete pad.

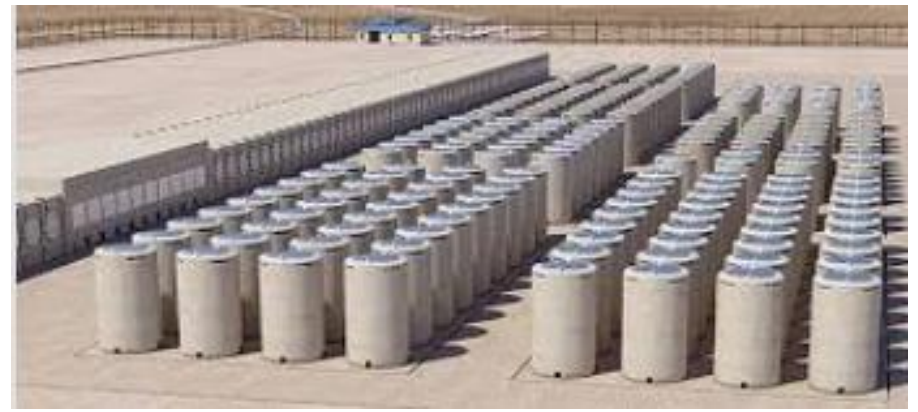

Figure 29. Illustration of NAC MPCs (Right) on a CISF Storage Pad. 


\subsubsection{Orano TN}

Orano TN (TN) suggested their Standardized NUHOMS ${ }^{\circledR}$ system (61BTH or 32 PTH1-L) and NUHOMS ${ }^{\circledR}$ EOS system (EOS-37PTH) can be adapted to accommodate the loaded DOE SNF Standardized Canisters. The particular type of NUHOMS ${ }^{\circledR}$ Dry Shielded Canister (DSC) in conjunction with their NUHOMS ${ }^{\circledR}$ Horizontal Storage Module (HSM) or NUHOMS ${ }^{\circledR}$ MATRIX systems could be used for storage of DOE SNF Standardized Canisters. The NUHOMS DSCs loaded with DOE SNF Standardized Canisters can be loaded into a NUHOMS MP197HB transportation cask for transport. All these systems are NRC licensed (or are in the licensing process and are expected to be licensed within the next year) and could have amendments to allow them to store and transport DOE SNF Standardized Canisters.

Based on initial assessments, the different TN systems could easily accommodate DOE SNF Standardized Canisters. The number of different DOE SNF Standardized Canisters that the TN system could be loaded with is listed in Table 3 .

Table 3. Number of DOE SNF Standardized Canisters in Different TN Systems.

\begin{tabular}{|c|c|c|c|}
\hline Canister & 61BTH & 32PTH1-L & OS-37PTH \\
\hline Small-Short (18”x10') & 8 & 9 & 12 \\
\hline Small-Long (18"x15') & 8 & 9 & 12 \\
\hline Large-Short (24"x10') & 5 & 5 & 7 \\
\hline Large-Long (24"x15') & 5 & 5 & 7 \\
\hline
\end{tabular}

\subsubsection{NUHOMS}

The NUHOMS system uses DSCs placed in HSMs. Horizontal systems have the advantages of that they cannot tip over, and onsite handling of these heavy systems is simple and safer in the horizontal position. Plus, the horizontal orientation during storage avoids the significant temperature difference between the two canister ends of a vertical system, reducing the possibility of thermally induced stresses in the material. Horizontal systems are easy to inspect and transport. Most importantly, TN's horizontal storage modules are arranged gap-free, side-by-side, which all but eliminates radiation emissions and results in minimal exposure to workers and the public.

NUHOMS ${ }^{\circledR}$ Horizontal Storage offers:

- Best shielding due to gap-free, side-by-side arrangement

- Highest level of safety

- Highly corrosion-resistant stainless-steel canisters, plus the duplex stainless-steel option for marine environments

- Massive concrete storage modules for a fortress like protection of the used fuel

- Lowest risk in moving fuel on-site due to horizontal orientation

- Highest seismic performance of any system

- NRC-licensed cask to transport canisterized high burn-up fuel

- Surest path to moving used fuel away from nuclear plants to the WCS Interim Storage Facility

- Major safety features as a result of conservative design and conduction of heat, rather than relying on convection.

Figure 30 provides a diagram of the NUHOMS system with the various components identified, and descriptive paragraphs. 


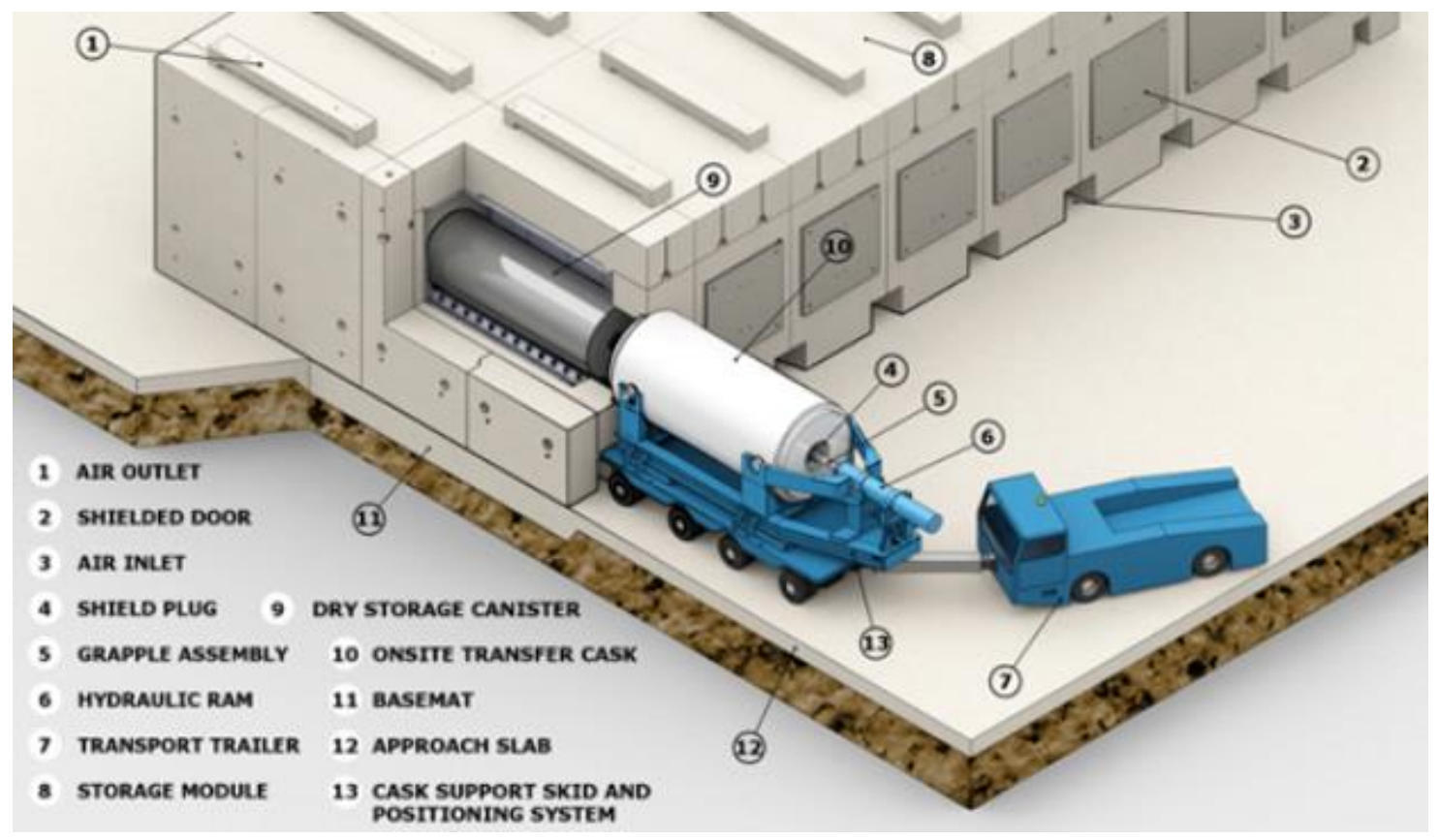

Figure 30. Diagram of NUHOMS System.

Dry Shielded Canister (DSC, \#9 in Figure 30)

The NUHOMS ${ }^{\circledR}$ DSC is a state-of-the-art canister that TN has designed and licensed for safe storage and transport of used fuel. The NUHOMS $®$ canister has a strong containment shell that is made up of up to $5 / 8 "$ thick highly corrosion-resistant stainless steel. The canister has uninterrupted aluminum heat conductive pathways and crisscrossed slotted plates. The slotted plates enable heat conduction so that the heat from the fuel assemblies on the interior of the canister can easily conduct to the sides of the canister where the heat is then dissipated by the air flow. The horizontal configuration allows for the heat to be removed from the fuel more efficiently over a large area and also distributes weight more evenly for maximum safety and stability during transfer or transport.

Transfer Cask (TC, \#10 in Figure 30)

The NUHOMS Transfer Cask (TC) is used to safely move the horizontal loaded DSC from the loading point to the storage site for insertion of the loaded DSC into the HSM. TN's experienced and practiced team of experts -- who have consistently demonstrated industry-best performance -- can manage this "pool to pad" process for the site. NUHOMS University offers real-time training with full-size components and equipment to ensure the pool to pad transfer is completed incident-free, on-time and on-budget.

Horizontal Storage Module (HSM, \#8 in Figure 30)

NUHOMS systems have the highest seismic capability available, due to the fortress-like HSMs. In addition, HSMs have proven flood performance and have high tornado wind and missile tolerances. Each HSM has internal heat shields and a shield door. The HSMs are arranged in an array that offers added shielding through the side-by-side configuration. The ends of each array include additional shielding and the roof of the concrete reinforced module is four feet thick. This heavy shielding results in no measurable dose to the public.

Figure 31 shows a closer cutaway view of the NUHOMS system. Figure 32 shows a photo of a NUHOMS DSC being loaded into a HSM. 


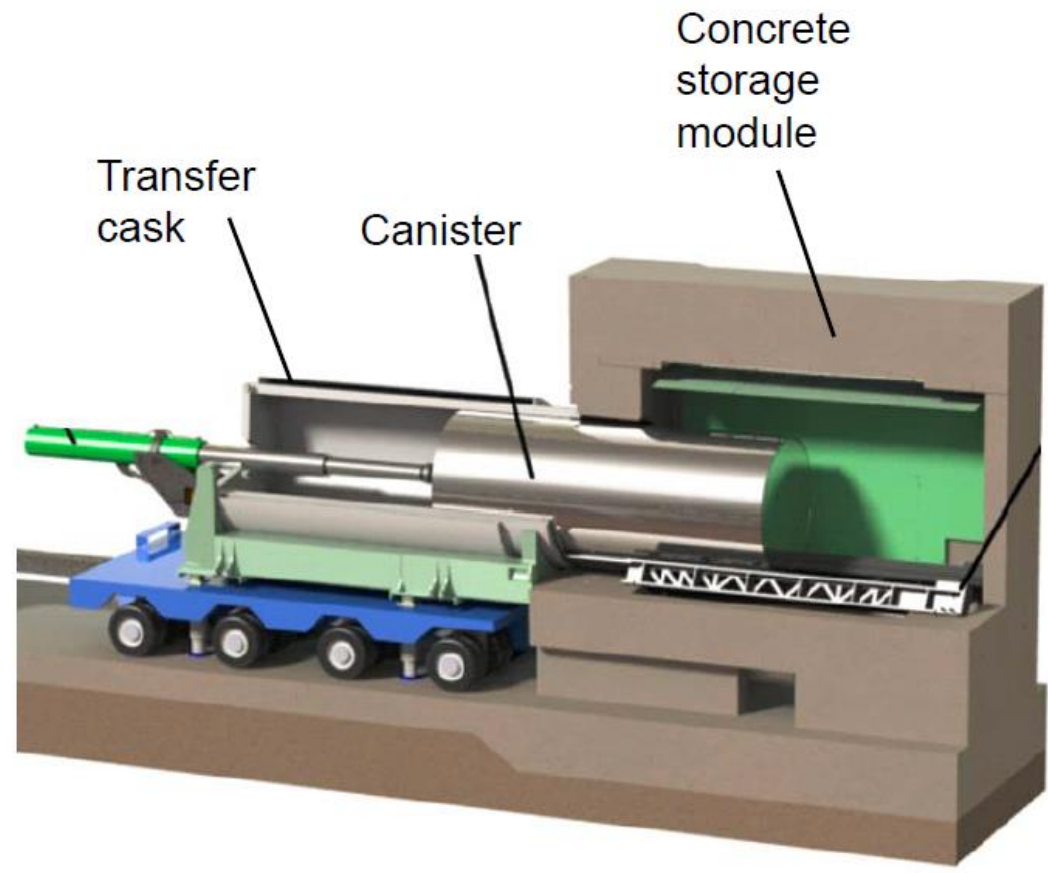

Figure 31. Cutaway View of NUHOMS Transfer Cask and Concrete Storage Module.

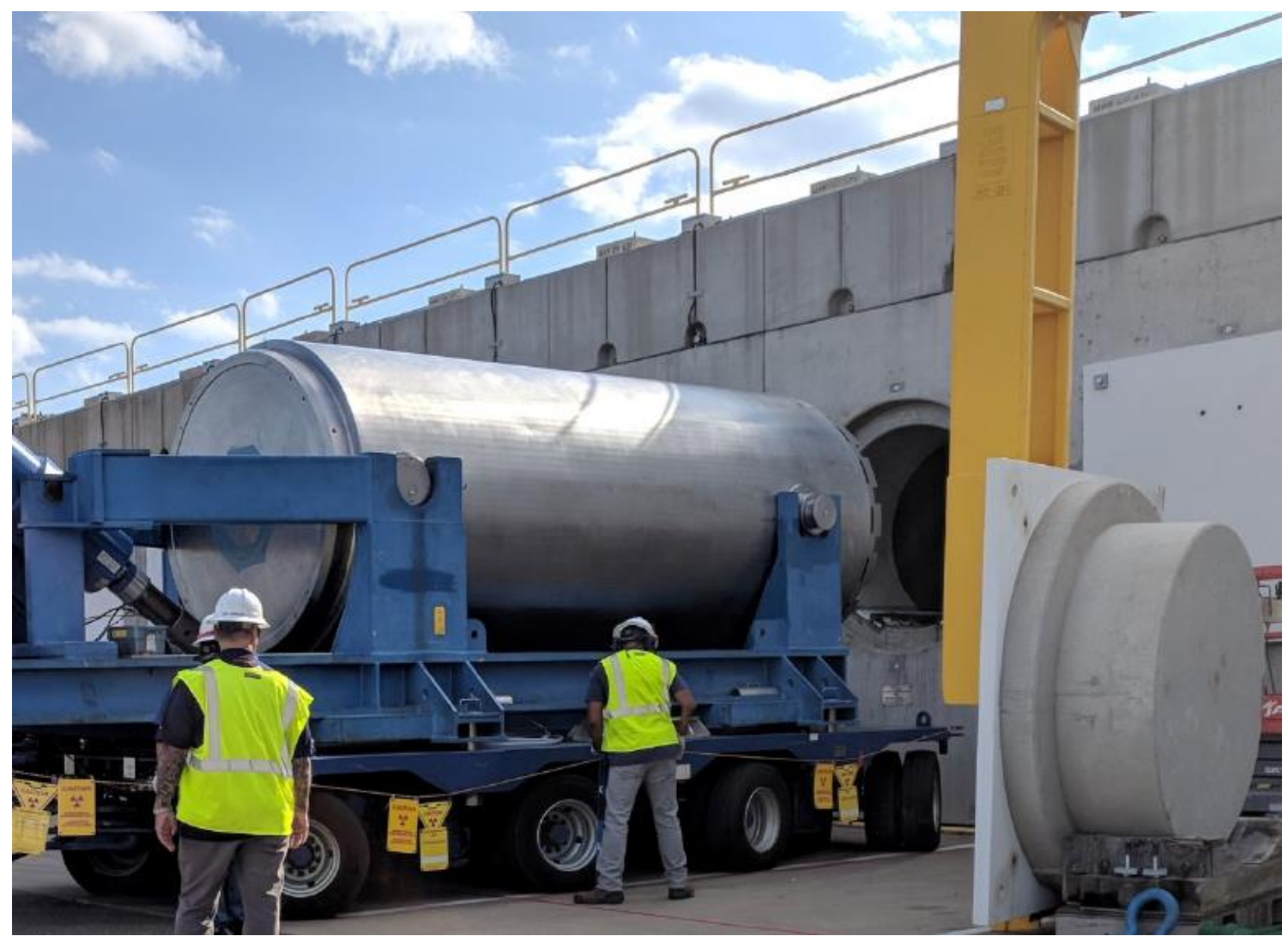

Figure 32. Loading of a NUHOMS DSC into a HSM. 


\section{MP197HB Transport Cask}

The NUHOMS DSC can be removed from the HSM and placed in a NUHOMS MP197HB transportation cask for shippment offsite. The MP197HB is a shielded cask that consists of a containment boundary, structural shell, gamma shielding material, and solid neutron shield. Impact limiters are attached to each end of the NUHOMS MP197HB cask during shipment. Figure 33 shows a picture of a NUHOMS MP197HB transportation cask.

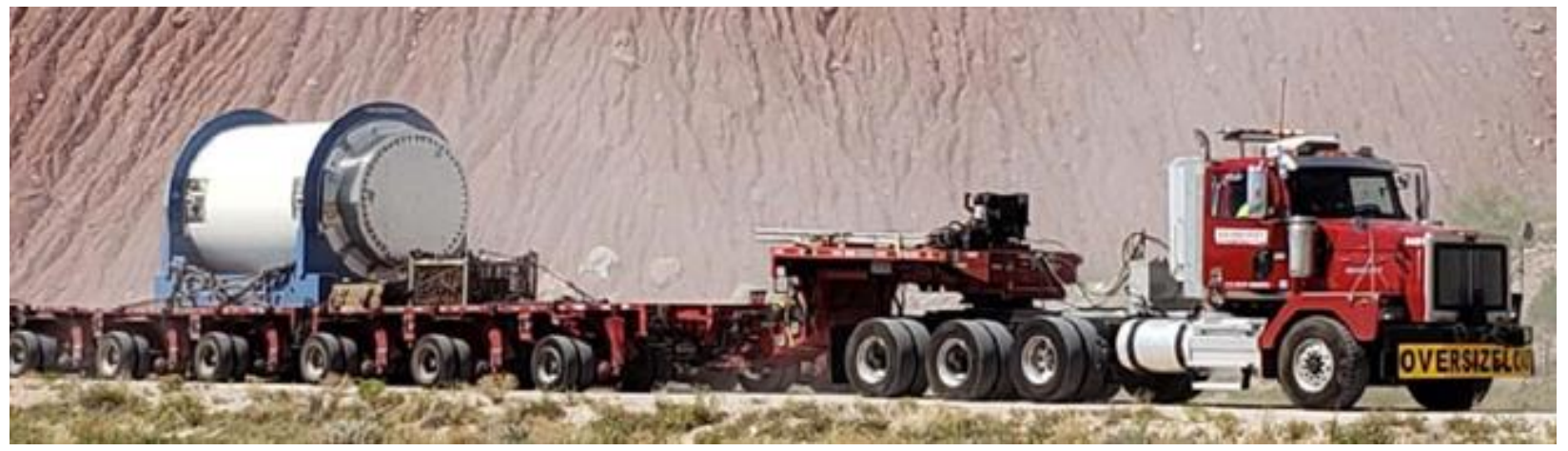

Figure 33. NUHOMS MP197HB transportation cask.

\subsubsection{NUHOMS ${ }^{\circledR}$ MATRIX}

This innovative two-level concrete overpack design for used nuclear fuel storage reduces the footprint requirements of an ISFSI by as much as $45 \%$ when compared to existing dry storage technologies. The universal horizontal MATRIX overpack also meets all storage requirements for shutdown and operating U.S. nuclear reactors, including the storage of high-burnup short-cooled fuel, and is designed to accommodate used fuel storage canisters with different diameters and lengths. For extended used fuel storage and aging management requirements, the MATRIX integrates new design features and devices which enable the complete inspection of the stored canister without removing it from the module.

Key MATRIX features:

- $45 \%$ footprint reduction for same storage capacity

- Store canisters with different diameters and lengths

- Specifically designed to address needs of shutdown or soon to be shut down sites

- Ideal option instead of expanding operating ISFSI pad

- Optimized for heat rejection, shielding and footprint

- Simplified aging management inspection with Retractable Roller Tray, now ALARA

Figure 34 has a picture of the NUHOMS MATRIX HSM. Figure 35 has an illustration of the loading system for MATRIX. 


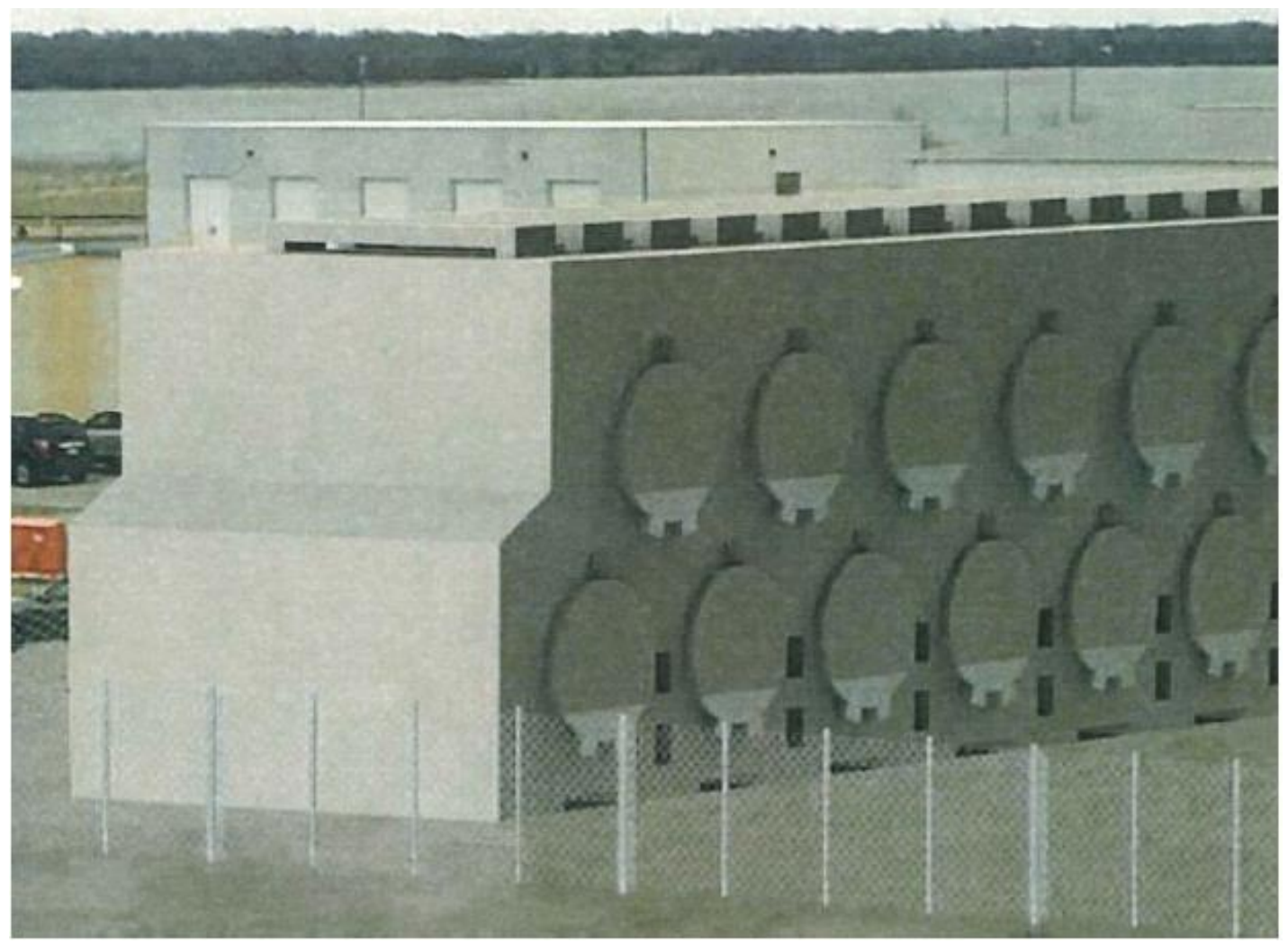

Figure 34. NUHOMS ${ }^{\circledR}$ MATRIX.

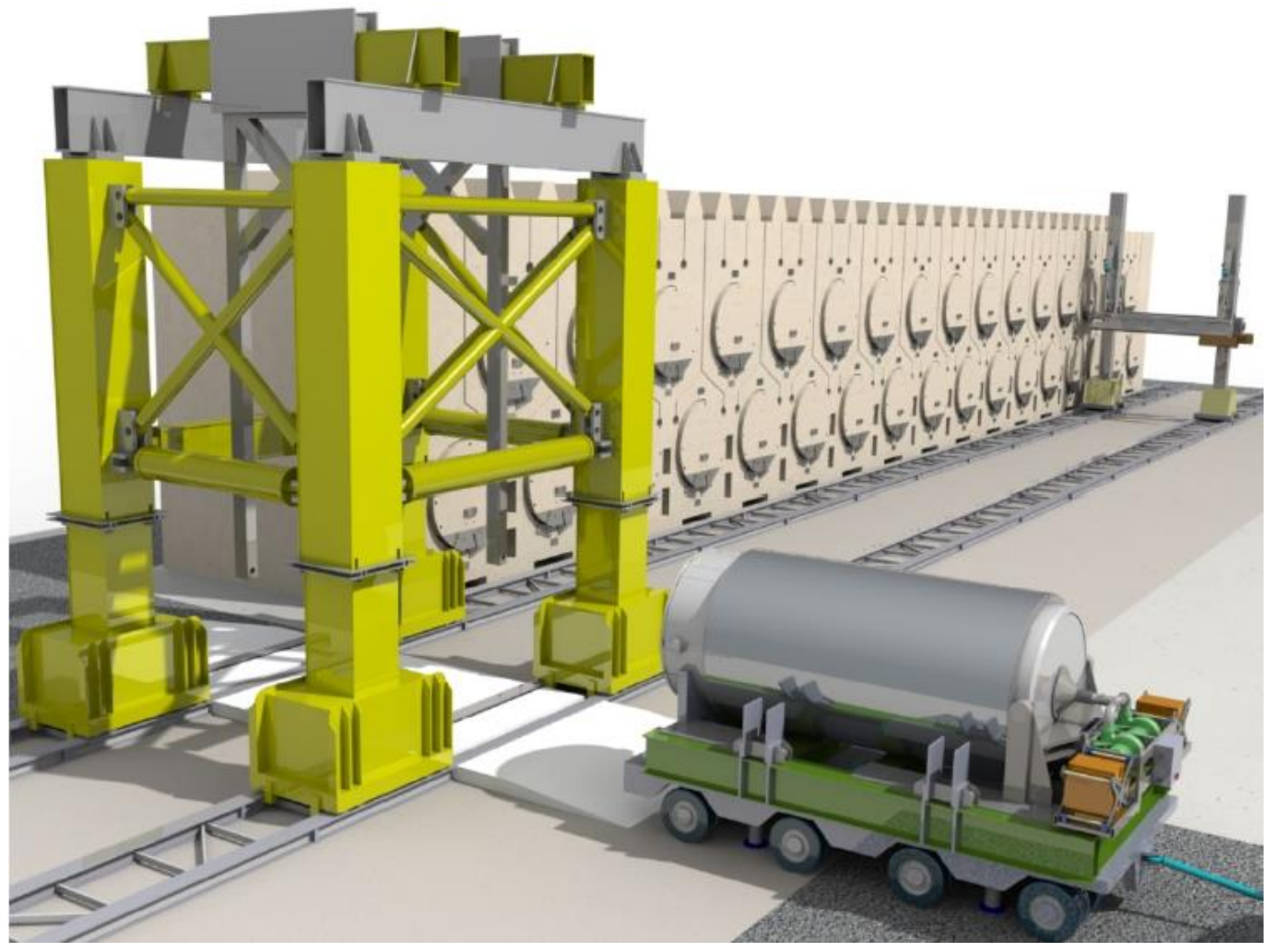

Figure 35. MATRIX Loading System. 


\subsubsection{TN Storage Locations}

The TN storage system are stored in concrete bunkers (NUHOMS HSM or NUHOMS MATRIX HSM) on a concrete pad (like CPP-1774, which currently has older TN NUHOMS HSM and storage casks stored on it).

\subsubsection{Waste Control Specialists CISF}

WCS, with partners Orano USA and NAC International, have submitted an application to the NRC for a license to construct and operate a CISF for used nuclear fuel in west Texas. Similar to the Holtec system, this CISF is being licensed for commercial SNF. It is expected that the license could be amended for DOE-owned SNF to be stored in a separate area (with any additional required security measures). Figure 36 has an illustration of NUHOMS HSMs on a CISF concrete pad

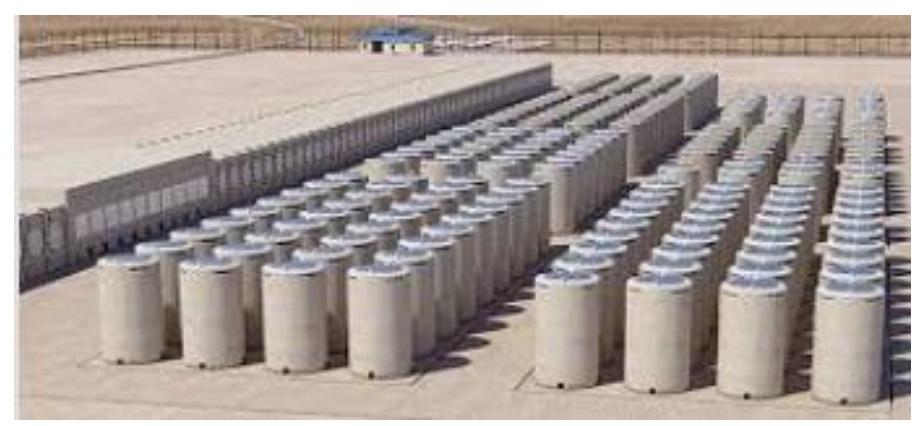

Figure 36. Illustration of NUHOMS HSMs (Left) on a CISF Storage Pad. 


\section{Factors}

A set of eight factors were established for considering and evaluating the storage configuration alternatives. The seven factors include 1) capacity, 2) interface with DOE SNF Standardized Canisters, 3) impact to facility operations, 4) initial capital costs, 5) per unit cost, 6) expenditure rate, 7) licensing issues, and 8 ) road ready conditions. The factors are described in the following sections.

\subsection{Capacity}

The 'capacity' factor in this study is how many of the four types of DOE SNF Standardize Canisters the storage configuration alternative can store. The number of each type of DOE SNF Standardized Canisters that needs to be stored depends on the size of the fuel assemblies, the basket arrangement selected for the fuel, and the number of fuel assemblies. The size determined what minimum sized is needed (e.g., the Peach Bottom fuel elements are too long to fit in either short canister). The basket arrangement determines the number of fuel elements per canister and size of canisters (e.g., ATR assemblies could be loaded 20 or 32 per 18"x 10' canister, 20 or 40 per 24 'x10' canister, or 40 or 60 per 24 "x $15^{\prime}$ canister). The number of fuel elements, divided by the number of fuel elements per canister, rounded up to the nearest whole number, determines the number of DOE SNF Standardized Canisters needed for a given fuel type. However, some fuel is still being generated (e.g., ATR fuel) and some basket arrangements are still being finalized, so he total number of canisters needed is not known. Table 4 contains the projected numbers of different types of canisters assumed for this study.

Table 4. Projected Number of Different DOE SNF Standardized Canisters.

\begin{tabular}{|c|c|c|}
\hline Canister Type & $\begin{array}{c}\text { Number } \\
\text { (Complex) }\end{array}$ & $\begin{array}{c}\text { Number } \\
\text { (INL Site) }\end{array}$ \\
\hline Small-Short (18'x10') & 1569 & 516 \\
\hline Small-Long (18'x15') & 1270 & 732 \\
\hline Large-Short (24"x10') & 133 & 0 \\
\hline Large-Long (24"x15') & 27 & 27 \\
\hline
\end{tabular}

For this study, the number of DOE SNF Standardized Canisters a storage configuration alternative can store is divided into three categories. The categories are:

1. Unlimited - good for the entire inventory,

2. Limited - good for a campaign of one or more SNF types or several smaller,

3. Demo Only - only good for a demonstration or smaller inventory SNF type,

With respect to the number of canisters associated with a category, the "Unlimited" category is easy to define, but the divide between "Limited" and "Demo Only" categories is more arbitrary. For purposes of this study, the divide is set at 40 canisters. If a storage configuration alternative can only store 40 or less DOE SNF Standardized Canisters, it is categorized as "Demo Only". If a storage configuration alternative can store more than 40 DOE SNF Standardized Canisters, but not all of them, it is categorized as "Limited".

The capacity factor categories are used to divide the different storage configuration alternatives into groups. The storage configuration alternative within a group are compared to one another using the other factors. The other factors, with their color coding and weighting, are used to determine the ranking of a storage configuration alternative within the capacity factor group. 


\subsection{Interface}

The "interface" factor in this study is how the storage configuration alternative can interface with the DOE SNF Standardized Canisters. The 4 categories from least to most impact/interface issue are:

1. No interface issues,

2. Minor interface issues,

3. Major interface issues, and

4. Cannot interface.

Newly built facilities, specifically designed for DOE SNF Standardized Canisters, and facilities that happen to be sized sufficiently to accept DOE S SNF Standardized Canisters may have no interface issues, at least for some sizes of canisters. A number of facilities may have some areas that will not accommodate larger sized canisters. Other facilities may need a minor modification (e.g., an interface sleeve to place a canister in a larger diameter or deeper floor well/liner/sleeve/etc.), and other may need major modifications to accommodate canisters.

In the evaluation, "no interface issues" are coded "green" and weighted 2 points, "minor interface issues" are coded "yellow" and weighted 1 point, and "major interface issues" are coded "red" and weighted 0 points. If the storage configuration cannot interface with any of the DOE SNF Standardized Canisters, the alternative is dropped from consideration.

\subsection{Impact on Facility Operations}

The 'impact on facility operations' factor in this study is how the storage of DOE SNF Standardized Canisters in the storage configuration alternative would impact current or planned operations with the facility and its current mission(s). The 4 categories from least to most impact are:

1. No impact,

2. Minor Impact,

3. Major Impact, and

4. Stop operations.

At one extreme, the "no impact" on facility operations could be for a purposefully built facility, whose mission is storage of the canisters. A "minor impact" might slow operations or cut down the flexibility of operations at the facility. If the storage of DOE SNF Standardized Canisters in the facility would prevent the facility from performing part of its mission, that would be a major impact. The other extreme is if storage of DOE SNF Standardized Canisters would stop operations at the facility.

In the evaluation, "no impacts" are coded "green" and weighted 2 points, "no significant impact" and "minor impacts" are coded "yellow" and weighted 1 point, and "major impacts" are coded "red" and weighted 0 points. If the storage configuration facility cannot operate if DOE SNF Standardized Canisters are stored there, the alternative is dropped from consideration. 


\subsection{Initial Capital Costs}

The 'initial capital cost' factor in this study is the total initial cost of storing the first (or first group) of DOE SNF Standardized Canisters with the storage alternative. In general this will include physical items (materials, construction, fabrication, purchase of equipment, etc.) and the cost to license the storage of DOE SNF Standardized Canisters in the storage configuration alternative. The full details of a capital cost analysis is beyond the scope of this study. So the 'initial capital cost' factor is only going to be considered in relative terms based on available rough order of magnitude values, unless specific cost information is available. For purposes of the study, costs are divided into 3 categories:

1. Low,

2. Medium, and

3. High

In general terms, low cost factor is less than $\$ 10$ million, medium cost factor is up to $\$ 100$ million dollars, and high is greater than a hundred million dollars.

In the evaluation, "low costs" are coded "green" and weighted 2 points, "medium costs" are coded "yellow" and weighted 1 point, and "high costs" are coded "red" and weighted 0 points.

\subsection{Per Unit Costs}

The 'per unit cost' factor in this study is the averaged cost to store a DOE SNF Standardized Canister using the storage alternative. In general, this is the total deployment cost (including the initial capital cost items (Section 3.4) plus any per canister cost) divided by the number DOE SNF Standardized Canisters in the storage configuration alternative. Based on the available rough order of magnitude cost information, there was not enough information to differentiate between different storage configuration alternatives, so this factor was not used.

\subsection{Expenditure Rate}

The 'expenditure rate' factor in this study is the cost per year of the storage alternative. Some storage alternatives require a full capital expenditure to perform storage and requires multi-year project that requires large minimum expenditure rates each year during the project performance, like in the case of a new large facility. For other storage alternatives, like in the case of module systems, the expenditure rate can be flexible (e.g., buy 10 units rather than 20 units in a given year can nearly half the cost). This factor will be ranked in terms of flexible or not. The 3 categories used in the study are:

1. High Flexible/Low Cost,

2. Medium Flexibility/Cost per year, and

3. Inflexible/High per year

In the evaluation, "high flexibility or low costs per year" are coded "green" and weighted 2 points, "medium flexibility or costs per year" are coded "yellow" and weighted 1 point, and "inflexible or high costs per year" are coded "red" and weighted 0 points. 


\subsection{Licensing}

The term 'Licensing' is being used in this study to cover both the NRC licensing process and the DOE safety basis process (10 CFR 830), and the term 'Amendment' is used to cover both a change to an NRC license and a DOE changed safety analysis. Before the Licensing factor can be address, a decision needs to be made: should the storage alternative be licensed under DOE regulations or NRC regulations? Both regulations ensure safety, but one can be more efficient (cost, time, and personnel to perform the review and address issues) than the other depending on the scope of the review (an amendment or new license) and the familiarity of the reviewing staff with the process $\left(\mathrm{N}^{\text {th }}\right.$ of a kind, or $1^{\text {st }}$ of a kind). This decision can vary between a demonstration project and a full project. Most of the existing INL INTEC facilities are DOE licensed. The exception is the CPP-1774 TMI ISFSI, which is NRC licensed.

For a demonstration project, amending the license of a current facility using the same regulatory body is likely the most efficient (e.g., a few demonstration storage units to be placed on the DOE licensed CPP-2707 Cask Pad Facility should be licensed with an amendment to the CPP-2707 Cask Pad Facility's DOE license). For a full project, using or modifying an existing facility, amending the license of a current facility using the same regulatory body is likely the most efficient (e.g., storing DOE SNF Standardized Canisters in the CPP-603 Facility's FSA, adding storage racks to modified Fuel Pool Areas (FPAs) in the CPP-666 FAST). For new facilities or modules, there may be advantages for obtaining an NRC license, due to expected downstream interfaces (e.g., amending an existing NRC transportation Certificate of Compliance associates with a canister-cask system).

The 'licensing' factor in this study is how efficiency or the amount of effort to licensing the existing, modified, or new facility for storing DOE SNF Standardized Canisters. The 4 categories from most efficient/least effort to least efficient/most effort are:

1. $\mathrm{N}^{\text {th }}$ of a kind amendment to existing license,

2. $1^{\text {st }}$ of a kind amendment to existing license,

3. $\mathrm{N}^{\text {th }}$ of a kind new license,

4. $1^{\text {st }}$ of a kind new license.

In the evaluation, " $\mathrm{N}^{\text {th }}$ of a kind amendment to existing license" is coded "green" and weighted 2 points, " 1 st of a kind amendment to existing license" and " $\mathrm{N}^{\text {th }}$ of a kind new license" are coded "yellow" and weighted 1 point, and " 1 st of a kind new license" is coded "red" and weighted 0 points. If the storage configuration facility has already been licensed for DOE SNF Standardized Canisters, it is also coded "green" and weighted 2 points.

\subsection{Road Ready}

The 'road ready' factor in this study is related to the Idaho Settlement Agreement (ISA), and relates to how easy will it be to move the canisters stored with a given alternative, to a site outside the State of Idaho (e.g., an ISFSI or repository). The 3 categories for the "road ready" factor used in the study are:

1. High,

2. Medium, and

3. Low.

The "high" category represents storage configuration alternatives that are readily able to interface with transportation systems (e.g., and MPC canister that can be placed directly into a transportation cask for 
shipping). The "medium" category represents storage configuration alternatives that are able to support interface with transportation systems (e.g., have a transfer system/cell able to interface with a transfer cask, that can then interface with a transportation system). The "low" category represents storage configuration alternatives that need DOE SNF Standardized Canisters to be moved to a separate facility in order to be placed in a transfer system that can then interface with transportation systems.

In the evaluation, "high" are coded "green" and weighted 2 points, "medium" are coded "yellow" and weighted 1 point, and "low" are coded "red" and weighted 0 points. 


\section{Evaluation}

This section evaluates the existing facilities, modification to the existing facilities, new facilities, and new modular system with the factors discussed in Section 3.

\subsection{Existing Facilities}

\subsubsection{CPP-603 IFSF}

The description of the CPP-603 IFSF is given in Section 2.2.1. There are two potential areas to store DOE SNF Standardized Canisters in the CPP-603 facility: 1) in the Floor Wells of the FHC (the nine North Floor Wells and some of the six South Floor Wells) and 2) in the Storage Racks of the FSA. Since storage of canisters in the Floor Wells will disrupt or stop operations in the CPP-603 facility, it is discounted as an option for this study.

Capacity - The CPP-603 facility, based on currently planned wet-to-dry operations through 2021, will only have 23 available canister locations in the FSA Storage Racks to store DOE SNF Standardized Canisters. These 23 locations could only accommodate the small-short (18"x10') DOE SNF Standardized Canisters. It would be possible to unload fuel currently stored in Storage Canisters in the FSA Storage Racks into DOE SNF Standardized Canisters, but these would not necessarily be able to fit back into the FSA Storage Rack locations (e.g., Core 2 Peach Bottom fuel in FSA Storage Canisters would go into smalllong (18"x15') DOE SNF Standardized Canisters, which don't fit into the FSA), so a larger systems study would be required to check the viability of this "swapping", which is not within the scope of this study. Therefore, the capacity factor of the unmodified CPP-603 facility is rated "Demo Only".

Interface - The Storage Racks in the FSA currently requires canisters to hang from lips on the Storage Canister lids. Storing DOE SNF Standardized Canisters in the FSA Storage Racks would require development, analysis, testing, and licensing of adaptors to temporarily add the "lips" to interface with the Storage Rack. This is classified as a "Minor Interface Issue", so the interface factor of the unmodified CPP603 facility is rated Yellow.

Impact - Filling up all available FSA Storage Rack locations would limit the facility from accepting new fuel, without removing existing fuel. This is classified as a "Major Impact", so the impact factor of the unmodified CPP-603 facility is rated Red.

Initial Capital Costs - The only capital expenditures would be for the interface equipment, which are very minor. Therefore, the capital cost factor of the unmodified CPP-603 facility is rated Green.

Expenditure Rate - The costs for the interface equipment is fairly linear with the number to be loaded, and so is fairly flexible. Therefore, the expenditure rate factor of the unmodified CPP-603 facility is rated Green.

Licensing - The addition of new canisters in the FSA Storage Rack would require a license amendment, which has not been done recently. This would be considered a $1^{\text {st }}$ of a kind amendment. Therefore, the licensing factor of the unmodified CPP-603 facility is rated Yellow.

Road Ready - Storing DOE SNF Standardized Canisters in the CPP-603 facility does not make them any more ready for transport, however, since the CPP-603 facility can interface with transport systems (via

the FHC and CTP) it is better than just the canisters. Therefore, the road ready factor of the unmodified CPP-603 facility is rated Yellow. 


\subsubsection{CPP-666 FAST}

The description of the CPP-666 FAST is given in Section 2.2.2. The unmodified CPP-666 facility has no areas to store DOE SNF Standardized Canisters. Therefore, no further evaluation is performed for the unmodified CPP-666 facility.

\subsubsection{CPP-749 UGFSF}

The description of the CPP-749 UGFSF is given in Section 2.2.3. The unmodified CPP-749 facility has below-grade vertical vaults that can accept DOE SNF Standardized Canisters. There is a planned effort to empty the fuel from first generation vaults into second generation vaults due to water leakage concerns in the first generation vaults.

Capacity - The CPP-749 facility has limited free capacity, especially after the emptying of the first generation vaults. Current estimate is that there will be 7 vaults empty and able to accept DOE SNF Standardized Canisters. Therefore, the capacity factor of the unmodified CPP-749 facility is rated "Demo Only".

Interface - The interface of DOE SNF Standardized Canisters into the CPP-749 vertical vaults would require some interface adaptors, with associated analysis and licensing. This is classified as a "Minor Interface Issue", so the interface factor of the unmodified CPP-749 facility is rated Yellow.

Impact - Filling up all available vault locations would limit the facility from accepting new fuel, without removing existing fuel. This is classified as a "Major Impact", so the impact factor of the unmodified CPP749 facility is rated Red.

Initial Capital Costs - The only capital expenditures would be for the interface equipment (transfer cask and vault adaptor), which should be low. Therefore, the capital cost factor of the unmodified CPP-749 facility is rated Green.

Expenditure Rate - The costs for the interface equipment is linear with the number to be loaded, and so is fairly flexible. Therefore, the expenditure rate factor of the unmodified CPP-749 facility is rated Green.

Licensing - The addition of new types pf canisters in the vertical vaults would require a license amendment, which has not been done recently. This would be considered a $1^{\text {st }}$ of a kind amendment. Therefore, the licensing factor of the unmodified CPP-749 facility is rated Yellow.

Road Ready - Storing DOE SNF Standardized Canisters in the CPP-749 facility vertical vaults does not make them any more ready for transport. Therefore, the road ready factor of the unmodified CPP-749 facility is rated Red.

\subsubsection{CPP-1774 TMI ISFSI}

The description of the CPP-1774 TMI ISFSI is given in Section 2.2.4. The unmodified CPP-1774 facility has one empty HSM, which could physically accept a NUHOMS type canister with a capacity of from 5 to 12 DOE SNF Standardized Canisters, depending on the canisters size (see Section 2.4.3).

Capacity - The unmodified CPP-1774 TMI ISFSI can only accommodate one additional NUHOMS canister, with a capacity of from 4 to 12 DOE SNF Standardized Canisters, depending on the canisters size. This may be useful for a demonstration project, but not for a loading campaign. Therefore, the capacity factor of the unmodified CPP-1774 facility is rated "Demo Only". 
Interface - Placing DOE SNF Standardized Canisters in larger NUHOMS canisters and those canisters into the CPP-1774 HSM would have no interface issues. Therefore, the interface factor of the unmodified CPP-1774 facility is rated Green.

Impact - Filling up all available locations would normal be a major impact to facility operations, however there is no new TMI canisters for placement in the CPP-1774 facility. The only possible need for the HSM location is off-normal events associated with inspection issues. This is classified as a "Major Impact", so the impact factor of the unmodified CPP-17749 facility is rated Red.

Initial Capital Costs - The capital costs would be for a single NUHOMS canister, which is not large compared to other potential options. For a single cask system, the transfer cask and moving equipment would likely just be leased, if the current equipment is not compatible. Therefore, the capital cost factor of the unmodified CPP-1774 facility is rated Green.

Expenditure Rate - The purchase on a NUHOMS canister can be fairly flexible. However, with a single canister operation, all costs are incurred in a short amount of time, so flexibility is reduced in this case. Therefore, the expenditure rate factor of the unmodified CPP-1774 facility is rated Yellow.

Licensing - The addition of a new type of canister in the CPP-1774 facility would be a licensing amendment. This is done fairly frequently with other ISFSIs, so is a $\mathrm{N}^{\text {th }}$ of a kind licensing. Therefore, the licensing factor of the unmodified CPP-1774 facility is rated Green.

Road Ready - Storing DOE SNF Standardized Canisters in the CPP-1774 facility's HSM in NUHOMS canisters that are already licensed for transport, is a huge advantage for being road ready. A license amendment and available transportation overpack may take a year or less. Therefore, the road ready factor of the unmodified CPP-1774 facility is rated Green.

\subsubsection{CPP-2707 Cask Pad}

The description of the CPP-2707 Cask Pad is given in Section 2.2.5. The unmodified CPP-2707 pad has twelve empty locations, each of which could physically accept one modular cask/canister system with a capacity of from 4 to 12 DOE SNF Standardized Canisters, depending on the canisters size (see Section 2.4) and type of modular storage system.

Capacity - The unmodified CPP-2707 pad has twelve locations available to accept casks/storage modules. Depending on cask/modular type and size of the DOE SNF Standardized Canisters, that would allow storage of from 48 to 144 DOE SNF Standardized Canisters. The lower 48 capacity of DOE SNF Standardized Canisters could accommodate all the large-long DOE SNF Standardized Canisters currently needed for the INL site. Therefore, the capacity factor of the unmodified CPP-2707 facility is rated "Demo Only".

Interface - Placing DOE SNF Standardized Canisters in casks or larger canisters and placing those on the CPP-2707 pad would have no interface issues. Therefore, the interface factor of the unmodified CPP2707 facility is rated Green.

Impact - Filling up all available locations would normal be a major impact to facility operations, however there is no new casks planned for placement on the CPP-2707 Cask Pad. This is classified as a "No Impact", so the impact factor of the unmodified CPP-17749 facility is rated Green.

Initial Capital Costs - The initial capital costs would be for a storage canister and storage overpack plus handling equipment/transfer cask (if the current available ones are not compatible), which is not large compared to other potential options. Therefore, the capital cost factor of the unmodified CPP-1774 facility is rated Green. 
Expenditure Rate - The purchase on a NUHOMS canister can be fairly flexible. Therefore, the expenditure rate factor of the unmodified CPP-1774 facility is rated Green.

Licensing - The addition of a new type of canister on the CPP-2707 pad would be a licensing amendment. This type of amendment hasn't been done recently with DOE, so would be considered a $1^{\text {st }}$ of a kind amendment. Therefore, the licensing factor of the unmodified CPP-2707 facility is rated Yellow.

Road Ready - Storing DOE SNF Standardized Canisters in the modular cask systems, where the inner canisters is already licensed for transport, is a huge advantage for being road ready. A license amendment and available transportation overpack may take a year or less. Therefore, the road ready factor of the unmodified CPP-2707 facility is rated Green.

\subsubsection{MFC-771 RSWF}

The description of the MFC-771 RSWF is given in Section 2.2.6. The unmodified MFC-771 RSWF has below-grade steel lined vertical vaults that should be able to accommodate DOE SNF Standardized Canisters. Based on previous evaluations, up to 394 18" diameter and 97 24" diameter.

Capacity - The MFC-771 RSWF has limited free capacity. Based on previous assessments, there are no more than 394 vaults empty and able to accept DOE SNF Standardized Canisters. All of them could accept the 18" diameter canisters (with adaptors), but only 97 could accept 24" diameter canisters. They do not seem able to accommodate 15' long DOE SNF Standardized Canisters. Operations since the previous study, and currently planned operations have likely reduced the number of available positions, maybe significantly. Therefore, the capacity factor of the unmodified MFC-771 RSWF is rated "Limited".

Interface - The interface of DOE SNF Standardized Canisters into the MFC-771 vaults would require some interface adaptors, with associated analysis and licensing. This is classified as a "Minor Interface Issue", so the interface factor of the unmodified MFC-771 facility is rated Yellow.

Impact - Filling up all available locations would limit the facility from accepting new waste. This is classified as a "Major Impact" since operations are still ongoing, so the impact factor of the unmodified MFC-771 RSWF is rated Red.

Initial Capital Costs - The only capital expenditures would be for the interface equipment (transfer cask and liner adaptors), which should be low. Therefore, the capital cost factor of the unmodified MFC-771 RSWF is rated Green.

Expenditure Rate - The costs for the interface equipment is linear with the number to be loaded, and so is fairly flexible. Therefore, the expenditure rate factor of the unmodified MFC-771 RSWF is rated Green.

Licensing - The addition of new types pf canisters in the vertical vaults would require a license amendment, which has not been done recently. This would be considered a $1^{\text {st }}$ of a kind amendment. Therefore, the licensing factor of the unmodified MFC-771 RSWF is rated Yellow.

Road Ready - Storing DOE SNF Standardized Canisters in the MFC-771 RSWF vertical vaults does not make them any more ready for transport. Therefore, the road ready factor of the unmodified MFC-771 RSWF is rated Red.

\subsubsection{CPP-603 IFSF}

\subsection{Modifications to Existing Facilities}

There are no significant modifications envisioned for the CPP-603 facility. The DOE SNF Standardized Canister storage capacity and factors are as stated in Section 4.1.1. 


\subsubsection{CPP-666 FAST}

The potential modifications under consideration for the CPP-666 FAST is the conversion of Pool \#1 from a pool to a Dry Storage Area (DSA) and the conversion of Isolation Pool \#2 from a pool to a Dry Fuel Transfer area (similar to the CPP-603 FHC). The potential modification is described in a separate report ([11], Appendix L). The new DSA would have racks installed with double (for 15' long canisters) or triple (for 10' long canisters) levels. The new rack could have up to 180 horizontal positions for 18 " diameter DOE SNF Standardized Canisters, so up to 54018 "x10' or 36018 "x15'. To have enough room for all the 24"x15' DOE SNF Standardized Canisters on the INL site, approximate 3 rows of spots for 18" diameter canisters would need to be left out. This would leave up to 43218 "x10' or 28818 "x15' canisters positions. Figure 37 shows a view with 180 of the 18 " diameter storage rack locations in Pool \#1 of CPP-666. Figure 38 shows a cutaway view of the rack, with three levels of canisters and a detail on an ATR canister.

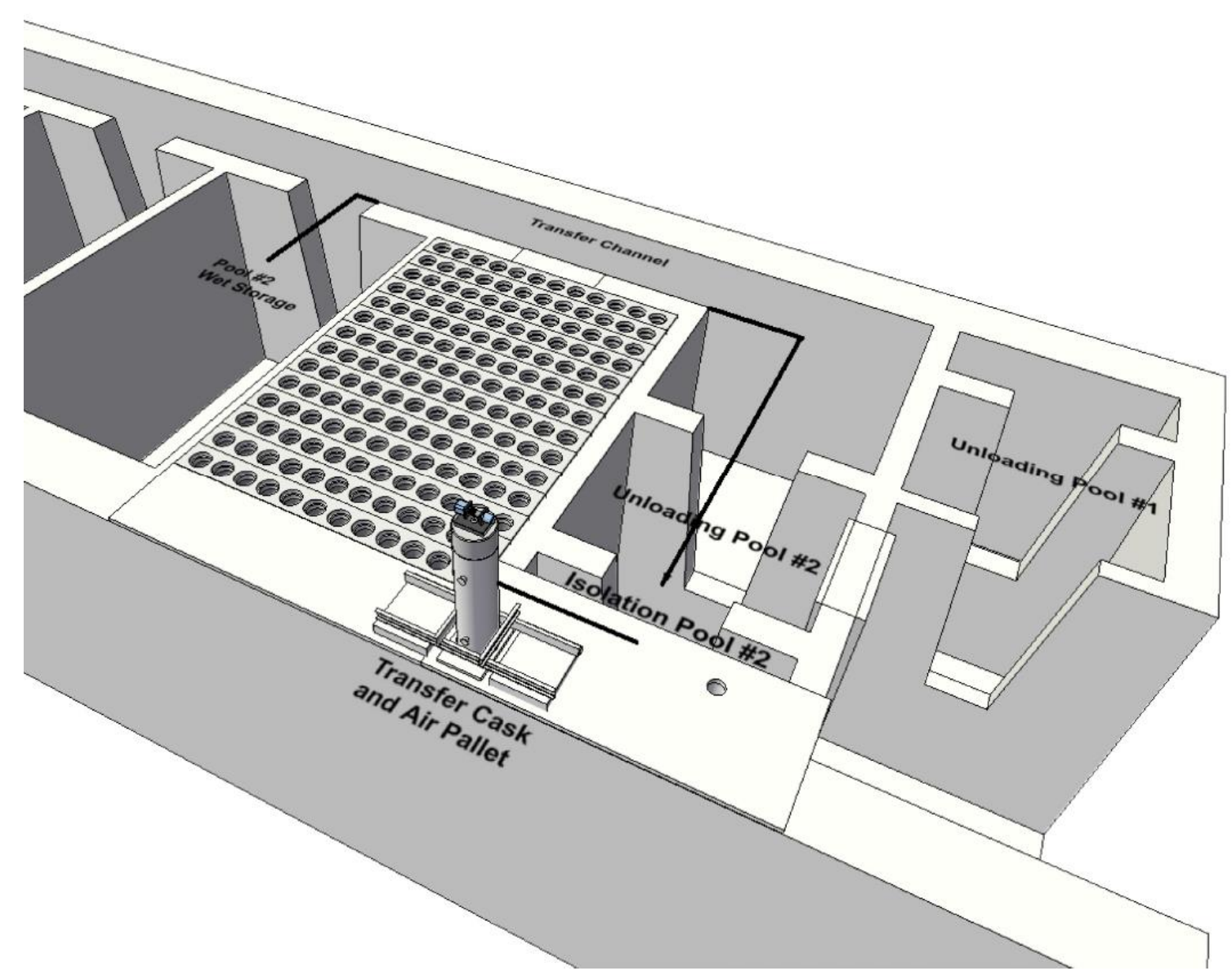

Figure 37. View of Proposed Change to CPP-666. 


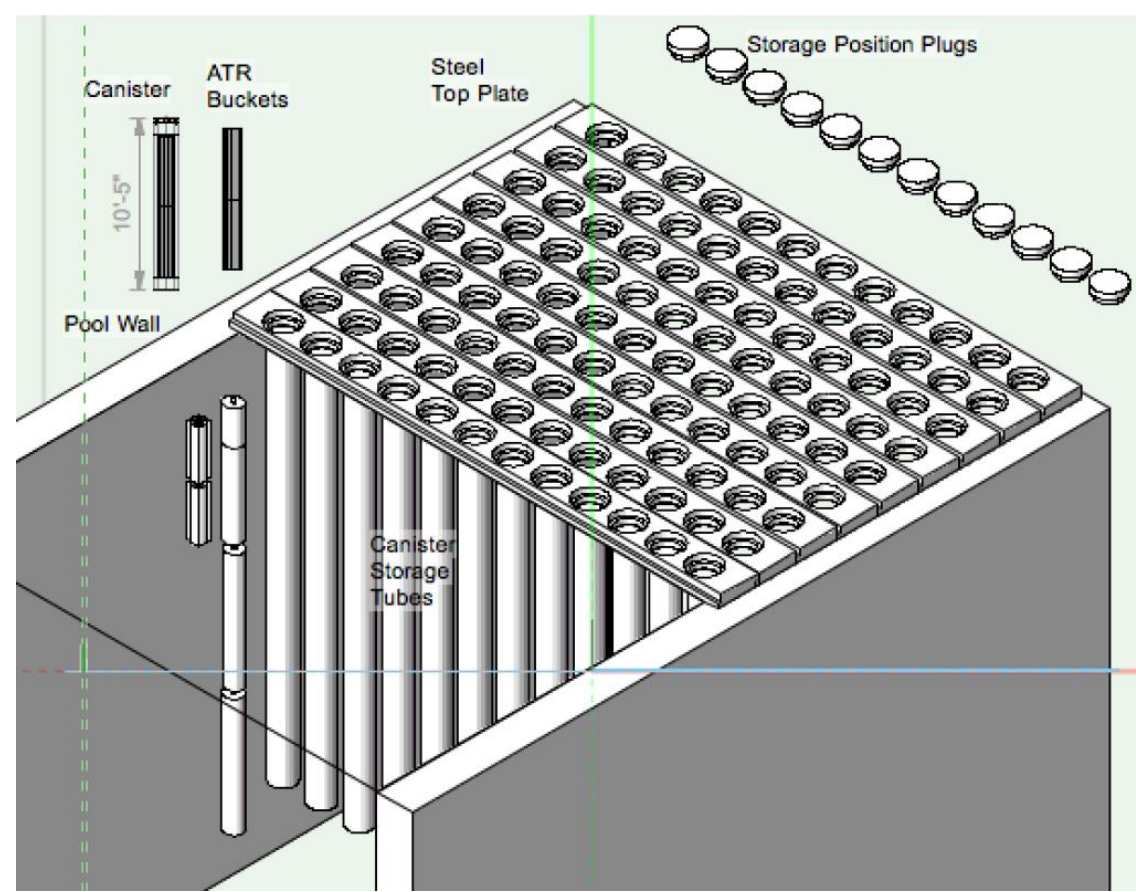

Figure 38. Cutaway View of Proposed Change to CPP-666.

Capacity - The new modified CPP-666 facility would not be able to accommodate all the DOE SNF Standardized Canisters for the INL site, however it could accommodate all the large-long (24'x15') and a significant number of small (18" OD) canisters. Therefore, the capacity factor of the new modified CPP666 facility is rated "Limited". More extensive modification, covering an additional two pools, might be able to change this to an "Unlimited" category, but with a more significant impact to operations.

Interface - There would be no interface issues for DOE SNF Standardized Canisters placed in the new modified CPP-666 facility. Therefore, the interface factor of the new modified CPP-666 facility is rated Green.

Impact - The modification to allow storage of DOE SNF Standardized Canisters in the CPP-666 facility would impact the facility's ability to perform some operations and reduced its capacity to wet store fuel. However, the need for these functions is lessoning with a switch in mission, so the impact is downgraded from a "Major Impact" to a "Minor Impact". Therefore, the impact factor of the new modified CPP-666 facility is rated Yellow.

Initial Capital Costs - The capital costs for installing a storage rack would likely be in the medium range. Therefore, the capital cost factor of the new modified CPP-666 facility is rated Yellow.

Expenditure Rate - The modifications to the CPP-666 facility require large upfront expenditures for construction, with only moderate flexible. Therefore, the expenditure rate factor of the new modified CPP666 facility is rated Yellow.

Licensing - A new type of storage rack for canisters will require a new license, which has not been done recently. This would be considered a $1^{\text {st }}$ of a kind new license. Therefore, the licensing factor of the new modified CPP-666 facility is rated Red.

Road Ready - Storing DOE SNF Standardized Canisters in the CPP-666 facility does not make them any more ready for transport. Therefore, the road ready factor of new modified CPP-666 facility is rated Red. 


\subsubsection{CPP-749 UGFSF}

The potential modification under consideration for the CPP-749 UGFSF are restoration and updates to the Generation I Vaults. These would not allow additional canister storage capacity, but could allow storage of the 15' long DOE SNF Standardized Canisters.

Capacity - The CPP-749 facility has limited free capacity. Based on previous assessments, there are no more than 62 vaults empty and able to accept DOE SNF Standardized Canisters. Therefore, the capacity factor of the new modified CPP-749 facility is rated "Limited".

Interface - The interface of DOE SNF Standardized Canisters into the CPP-749 vertical vaults would require some interface adaptors, with associated analysis and licensing. This is classified as a "Minor Interface Issue", so the interface factor of the new modified CPP-749 facility is rated Yellow.

Impact - Filling up all available vault locations would limit the facility from accepting new fuel, without removing existing fuel. This is classified as a "Major Impact", so the impact factor of the new modified CPP-749 facility is rated Red.

Initial Capital Costs - The capital expenditures would include a fixed Generation I Vault and the interface equipment (transfer cask and vault adaptors), which should be low. Therefore, the capital cost factor of the unmodified CPP-749 facility is rated Green.

Expenditure Rate - The costs for the interface equipment is linear with the number to be loaded, and so is fairly flexible. Therefore, the expenditure rate factor of the new modified CPP-749 facility is rated Green.

Licensing - The addition of new types pf canisters in the vertical vaults would require a license amendment, which has not been done recently. This would be considered a $1^{\text {st }}$ of a kind amendment. Therefore, the licensing factor of the new modified CPP-749 facility is rated Yellow.

Road Ready - Storing DOE SNF Standardized Canisters in the CPP-749 facility vertical vaults does not make them any more ready for transport. Therefore, the road ready factor of the new modified CPP-749 facility is rated Red.

\subsubsection{CPP-1774 TMI ISFSI}

There are no modifications envisioned for the CPP-1774 facility. The DOE SNF Standardized Canister storage capacity and factors are as stated in Section 4.1.4.

\subsubsection{CPP-2707 Cask Pad}

There are no specific modifications envisioned for the CPP-2707 pad, but there is the possibility of increasing the packing density of storage modules on the pad (e.g., NUHOMS MATRIX), so that possibility is considered. The capacity can be considered limited, and the factor ratings remain the same as listed in Section 4.1.5. The DOE SNF Standardized Canister storage capacity and factors are as stated in Section 5.

\subsubsection{MFC-771 RSWF}

There are no modifications envisioned for the MFC-771 facility that would increase its capacity to store more DOE SNF Standardized Canisters. The DOE SNF Standardized Canister storage capacity and factors are as stated in Section 4.1.6. 


\subsection{New Facilities}

\subsubsection{Above-Grade, Singe Canister}

The Above-Grade, Single Canister (AG-SC) type of alternative could be a horizontal modular honeycomb configuration (similar to the NUHOMS MATRIX in Section 2.4.3.2, but for a larger number of smaller canisters) or could be a vertical configuration (similar to CPP-749 and MFC-771, but with a concrete bucker or silos within a berm above grade).

Capacity - Since this is a new facility/alternative, its capacity could be made to fit the DOE SNF Standardized Canister inventory for the entire DOE complex. The capacity factor for this storage configuration alternative is rated "Unlimited".

Interface - Since this is a new facility/alternative, it would be designed to have no interface issues. The interface factor for this storage configuration alternative is rated Green.

Impact - Since this is a new facility/alternative, it would be designed to have no impact on other operations. The impact factor for this storage configuration alternative is rated Green.

Initial Capital Costs - The majority of the costs are upfront site preparation and module/bunker/silo production, plus transfer cask and equipment. The capital cost factor for this storage configuration alternative is rated Yellow.

Expenditure Rate - Since this is a new facility/alternative, it could be designed fairly modular, to be somewhat flexible with annual costs. The expenditure rate factor for this storage configuration alternative is rated Yellow.

Licensing - This would represent a new license for something not necessarily done before. This would be considered a $1^{\text {st }}$ of a new license. Therefore, the licensing factor for this storage configuration alternative is rated Red.

Road Ready - Storing DOE SNF Standardized Canisters in these types of configurations does not make them road ready. Therefore, the road ready factor for this storage configuration alternative is rated Yellow.

\subsubsection{Above-Grade, Large Array of Canisters}

This type of alternative would be similar to the storage racks for CPP-603, but for a larger number of canisters.

Capacity - Since this is a new facility/alternative, its capacity could be made to fit the DOE SNF Standardized Canister inventory for the entire DOE complex. However the cost and complexity (e.g., seismic) of such a large building would likely be prohibitive, and a smaller structure with limited capacity built instead. The capacity factor for this storage configuration alternative is rated "Limited".

Interface - Since this is a new facility/alternative, it would be designed to have no interface issues. The interface factor for this storage configuration alternative is rated Green.

Impact - Since this is a new facility/alternative, it would be designed to have no impact on other operations. The impact factor for this storage configuration alternative is rated Green.

Initial Capital Costs - The capital costs for a large new building would be very high. The capital cost factor for this storage configuration alternative is rated Red.

Expenditure Rate - The expenditure rate of a large building would be high in order to meet a reasonable schedule, and this would not be very flexible. The expenditure rate factor for this storage configuration alternative is rated Red. 
Licensing - This would represent a new license for something done recently with the NRC (the ISFF) but not done very recently with DOE Regulators. Assuming DOE regulators, this would be considered a $1^{\text {st }}$ of a new license. Assuming NRC regulation, this would be considered a $\mathrm{N}^{\text {th }}$ of a kind new license. Therefore, the licensing factor for this storage configuration alternative is rated Red.

Road Ready - Storing DOE SNF Standardized Canisters in these types of configurations does not make them road ready. Therefore, the road ready factor for this storage configuration alternative is rated Yellow.

\subsubsection{Below Grade, Singe Canister}

This type of alternative would be similar to CPP-749 and MFC-771, but optimized for DOE SNF Standardized Canisters.

Capacity - Since this is a new facility/alternative, its capacity could be made to fit the DOE SNF Standardized Canister inventory for the entire DOE complex. The capacity factor for this storage configuration alternative is rated "Unlimited".

Interface - Since this is a new facility/alternative, it would be designed to have no interface issues. The interface factor for this storage configuration alternative is rated Green.

Impact - Since this is a new facility/alternative, it would be designed to have no impact on other operations. The impact factor for this storage configuration alternative is rated Green.

Initial Capital Costs - The majority of the costs are upfront site preparation (fences, security measures, and below grade silos) and transfer equipment. The capital costs for a large site could be significant, but this type of facility would lend itself to be near modular in construction. The capital cost factor for this storage configuration alternative is rated Yellow.

Expenditure Rate - Since this is a new facility/alternative, it could be designed fairly modular, to be somewhat flexible with annual costs. The expenditure rate factor for this storage configuration alternative is rated Green.

Licensing - This would represent a new license for something not necessarily done before. This would be considered a $1^{\text {st }}$ of a new license. Therefore, the licensing factor for this storage configuration alternative is rated Red.

Road Ready - Storing DOE SNF Standardized Canisters in these types of configurations does not make them road ready. Therefore, the road ready factor for this storage configuration alternative is rated Yellow.

\subsubsection{ISF Facility (Below-Grade, Large Array of Canisters)}

The description of the ISF Facility is given in Section 2.3.1. The ISF Facility as described is multifunctional, and not optimized for storage of large numbers of DOE SNF Standardized Canisters.

Capacity - The ISF Facility is not designed to accommodate all the DOE SNF Standardized Canisters for the INL site. Therefore, the capacity factor of the ISF Facility is rated "Limited".

Interface - Since this is a new facility/alternative, it would be designed to have no interface issues. The interface factor for this storage configuration alternative is rated Green.

Impact - Since this is a new facility/alternative, it would be designed to have no impact on other operations. The impact factor for this storage configuration alternative is rated Green.

Initial Capital Costs - The capital costs for a large new building would be very high. The capital cost factor for this storage configuration alternative is rated Red. 
Expenditure Rate - The expenditure rate of a large building would be high in order to meet a reasonable schedule, and this would not be very flexible. The expenditure rate factor for this storage configuration alternative is rated Red.

Licensing - This has been completed. Therefore, the licensing factor for this storage configuration alternative is rated Green.

Road Ready - Storing DOE SNF Standardized Canisters in these types of configurations does not make them road ready. Therefore, the road ready factor for this storage configuration alternative is rated Yellow.

\subsection{New Modular Systems}

A total of nine different new modular systems from the three commercial vendors were reviewed. All the vendors indicated that they would modify their recommended system based on details of the loading site, storage site, and what particular features were of interest to their customer (e.g., size of cask, capacity of casks, ability to reject heat, lower dose rates, ability to remove contamination, density on pad, etc.). The vendors all supplied very useful information, but since much of it was business sensitive (especially related to cost), it cannot be completely conveyed in this study. Insights from the WVDP Canister Storage Project (see Appendix A) are useful in understanding how the used of commercial vendor supplied modular storage systems could be beneficial for storing DOE SNF Standardized Canisters. The rating for the different factors follow, with additional information supplied on the cost factors.

Capacity - New modular systems can be expanded to match the needs of the DOE SNF Standardized Canister inventory for the entire DOE complex. The capacity factor for new modular storage configuration alternative is rated Unlimited.

Interface - The new modular system would be designed to have no interface issues. The interface factor for new modular storage configuration alternative is rated Green.

Impact- The new modular system would be designed to have no impact on other operations. The impact factor for new modular storage configuration alternative is rated Green.

Initial Capital Costs - There are a number of costs that would make up the costs of a new modular system. Besides the cost of the pad, the module costs include (storage 1-5, transport 6-9):

1. Cost of Licensing and Engineering for storage module ( $\$ 1-\$ 5$ million)

2. Cost of storage module ( $\$ 0.5-\$ 1.5$ million)

3. Cost of storage module canister handling equipment (buy or lease) (up to a few million)

4. Cost of loading operation for storage module (varies by number/size of campaign)

5. Cost of maintenance (very low per unit, remote versus manual)

6. Cost of Licensing and Engineering for transport module ( $\$ 0.5$ - \$3 million*)

7. Cost of transport module** (\$1.5 - \$3 million*)

8. Cost of unloading from storage/loading into transport system (\$0.1-\$0.5 million*)

9. Cost of shipping (rail versus truck, and number per shipment) ( $\$ 1$ million*)

* - Present cost, future cost in 5, 10, 20, or more years will vary

** - Reusable for multiple storage unit.

The values indicated in the above list are rough order of magnitude with rounding and averaging to obscure any business sensitive value given by the vendors. The ranges should bound values seen in a nearterm future proposal, but specific requested features may push the proposal outside the ranges indicated. Any future request for proposal will need to be very specific on required technical features, and ensure the proposed systems are not overdesigned for the storage of DOE SNF Standardized Canisters compared to their traditional payload of bare commercial SNF. 
Although not part of the initial capital cost evaluation, it is useful to know that a number of the costs are independent of number of modules, so more modules would mean these costs are spread over a larger number and the per module cost is lower. There is also some cost reduction per unit with larger orders of units (e.g., 10+, 20+, and 50+).

The cost per modular is fairly low, but with the pad and supporting equipment (transfer cask), the price will get into the medium range for the first unit. The capital cost factor for this storage configuration alternative is rated Yellow.

Expenditure Rate - Any of the new modular storage system would be flexible with annual costs. Even the Storage Pad and/or HSM could be expanded/built on an as-needed basis. The expenditure rate factor for this storage configuration alternative is rated Green.

Licensing - A huge advantage of these system, as note with the WVDP Canister Project (see Appendix A) is the ability to amend existing vendor NRC licenses. This would be considered a $\mathrm{N}^{\text {th }}$ of a kind license amendment. Therefore, the licensing factor for this storage configuration alternative is rated Green.

Road Ready - The new modular storage systems suggested by the various vendors were mostly storagetransport systems, but some "storage-only" systems were noted. However, even the "storage-only" could be transported with additional interface systems. The road ready factor for the "storage-only" systems is rated Yellow, and for the "storage-transport" systems is rated Green. 


\section{Summary and Conclusions}

From a review of the evaluation in this study, a number of different conclusions can be drawn. From a review of the capacity of the different storage configuration alternatives shown in Table 5, it can be seen that the available capacity in existing systems is very limited (especially if MFC-771 numbers are much lower, as is expected). The existing facilities are probably only viable for a demonstration project, or a campaign for a small-to-medium fuel group (e.g., Peach Bottom Core 2 fuel). Modification to the existing facilities provides more capacity and flexibility but are still limited and have the unstated issue of facility lifetime. The alternatives of new facilities or new modular systems are the only alternatives that can handle to full expected inventory of DOE SNF Standardized Canisters, either for the INL site or the whole DOE complex.

Table 5. Capacity of Storage Facility Alternatives

\begin{tabular}{|c|c|c|c|c|c|c|}
\hline Facility & Capacity & $\begin{array}{l}\text { Available } \\
\text { Capacity }\end{array}$ & $\begin{array}{c}\#^{\mathrm{F}} \text { of } \\
18^{\prime \prime} \times 10^{\prime}\end{array}$ & $\begin{array}{c}\#^{\mathrm{F}} \text { of } \\
18^{\prime \prime} \times 15^{\prime}\end{array}$ & $\begin{array}{c}\#^{\mathrm{F}} \text { of } \\
24^{\prime \prime} \times 10^{\prime}\end{array}$ & $\begin{array}{c}\#^{\mathrm{F}} \text { of } \\
24^{\prime \prime} \times 15^{\prime}\end{array}$ \\
\hline \multicolumn{7}{|c|}{ Existing Facilities } \\
\hline CPP-603 & 636 & 23 & 23 & 0 & 0 & 0 \\
\hline CPP-666 & 0 & 0 & 0 & 0 & 0 & 0 \\
\hline CPP-749 & 96 & $7^{\mathrm{D}}$ & 7 & 7 & 7 & 7 \\
\hline MFC-771 & 698 & $394^{\mathrm{E}}$ & $394^{\mathrm{E}}$ & 0 & $97^{\mathrm{E}}$ & 0 \\
\hline CPP-1774 & $30^{\mathrm{A}}$ & $1^{\mathrm{A}}$ & $1 \times 8-12$ & $1 \times 8-12$ & $1 \times 5-7$ & $1 \times 5-7$ \\
\hline CPP-2707 & $20^{\mathrm{A}}$ & $12^{\mathrm{A}}$ & $12 \times 7-12$ & $12 \times 7-12$ & $12 \times 4-7$ & $12 \times 4-7$ \\
\hline \multicolumn{7}{|c|}{ Modified Existing Facility } \\
\hline СРP-666 & $180^{B} / 135^{B}$ & $180^{B} / 135^{B}$ & 540 & 360 & 405 & 270 \\
\hline CPP-749 & 96 & $62^{c}$ & 62 & 62 & 62 & 62 \\
\hline CPP-2707 & $20^{\mathrm{A}}$ & $18-20^{A}$ & $18 \times 7-12$ & $18 \times 7-12$ & $18 \times 4-7$ & $18 \times 4-7$ \\
\hline \multicolumn{7}{|c|}{ New Facility } \\
\hline ISFF & 246 & 246 & 216 & 216 & 30 & 30 \\
\hline Others & \multicolumn{6}{|l|}{ Unlimited } \\
\hline
\end{tabular}

Notes: A - Number of multi-canister modules.

B - Number assuming all location fitted for 18 " canisters or 24 " canisters.

$\mathrm{C}$ - Number assuming all Generation I Vaults are refurbished are useable.

D - Number assuming all fuel in Generation I Vaults relocated to Generation II Vaults.

E - Numbers based on a 2017 report, that doesn't account for more recent operations. These capacities are likely reduced from the stated numbers.

F - Numbers of canisters are not additive (e.g., if 4 small-short (18"x10') canisters are placed in existing CPP-749, only up to 3 canisters of other sized can be placed there). 
Tables 6 through 9 show the summary of results for the evaluation. Table 6 divides the groups by existing facilities, modified facilities, new facilities, and new modular systems, while Tables 7 through 9 divide the groups into the capacity categories Demo Only (DO), Limited (L), and Unlimited (UL).

Table 6. Summary Rating of Storage Facility Alternatives

\begin{tabular}{|c|c|c|c|c|c|c|c|c|}
\hline & \multirow[b]{2}{*}{ 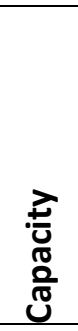 } & \multirow[b]{2}{*}{ 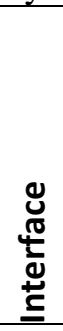 } & \multirow[b]{2}{*}{$\begin{array}{l} \\
\stackrel{t}{0} \\
\stackrel{0}{\varepsilon} \\
\underline{0}\end{array}$} & \multirow{2}{*}{\multicolumn{2}{|c|}{ 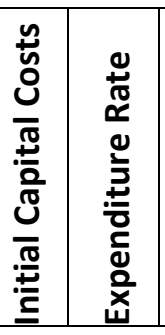 }} & \multirow[b]{2}{*}{ 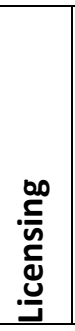 } & \multirow[b]{2}{*}{ 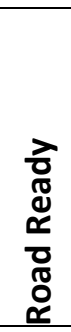 } & \multirow[b]{2}{*}{ 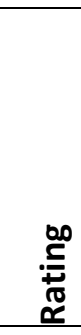 } \\
\hline & & & & & & & & \\
\hline \multicolumn{9}{|l|}{ Existing Facilities } \\
\hline CPP-603 & DO & 0 & - & + & + & 0 & 0 & 7 \\
\hline CPP-749 & DO & 0 & - & + & + & 0 & - & 6 \\
\hline MFC-771 & $\mathrm{L}$ & 0 & - & + & + & 0 & - & 6 \\
\hline CPP-1774 & DO & + & - & + & 0 & + & + & 9 \\
\hline CPP-2707 & DO & + & + & + & + & 0 & + & 11 \\
\hline \multicolumn{9}{|l|}{ Modified Existing Facility } \\
\hline CPP-666 & $\mathrm{L}$ & + & 0 & 0 & 0 & - & - & 5 \\
\hline CPP-749 & $\mathrm{L}$ & 0 & - & + & + & 0 & - & 6 \\
\hline CPP-2707 & $\mathrm{L}$ & + & + & 0 & + & 0 & + & 10 \\
\hline \multicolumn{9}{|l|}{ New Facility } \\
\hline Above-Grade, Single Canister & UL & + & + & 0 & 0 & - & 0 & 7 \\
\hline Above-Grade, Large Array & $\mathrm{L}$ & + & + & - & - & - & 0 & 5 \\
\hline Below-Grade, Single Canister & UL & + & + & 0 & + & - & 0 & 8 \\
\hline ISFF & $\mathrm{L}$ & + & + & - & - & + & 0 & 7 \\
\hline \multicolumn{9}{|l|}{ New Modular Systems } \\
\hline Storage & UL & + & + & 0 & + & + & 0 & 10 \\
\hline Storage \& Transport & UL & + & + & 0 & + & + & + & 11 \\
\hline
\end{tabular}

Note: For Capacity: DO = Demo Only, $\mathrm{L}=$ Limited, and UL $=$ Unlimited

The CPP-1774 and CPP-2707 facilities utilize the modular storage systems, so share most of their advantages other than unlimited capacity. They have high rankings or the "Demo Only" capacity factor category. Their flexibility in being able to handle all the different DOE SNF Standardized Canister sizes in useful too.

The Modified CPP-2707 facility and ISFF have the high rankings in the "Limited" capacity factor category. The fact that that the ISFF is already licensed is understated, but its cost and the fact it was not optimized for storage means its ranking is appropriate. Even the lower ranked Modified CPP-666 is still a viable storage alternative if multiple facilities are to be utilized and if facility lifetime is not an issue.

The new modular storage systems have high rankings in the "Unlimited" capacity factor category and useful system advantages and flexibility. Their ability to be scaled (e.g., a demonstration project using CPP-1774 or CPP-2707, to a new pad with $1,000+$ modules) and road ready are clear advantages to their use. 
Table 7. Summary Rating of Storage Facility Alternatives for Demo Only Capacity

\begin{tabular}{|c|c|c|c|c|c|c|c|}
\hline & 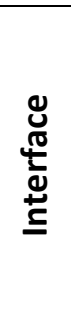 & $\begin{array}{l}\tilde{U} \\
\mathbb{0} \\
\stackrel{0}{\xi} \\
\underline{\xi}\end{array}$ & 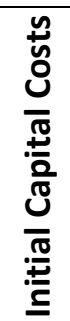 & 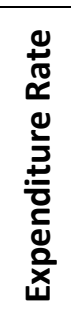 & 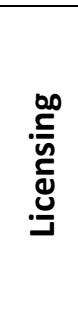 & 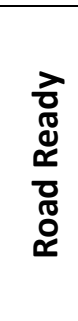 & 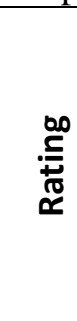 \\
\hline СРР-749 & 0 & - & + & + & 0 & - & 6 \\
\hline CPP-603 & 0 & - & + & + & 0 & 0 & 7 \\
\hline CPP-1774 & + & - & + & 0 & + & + & 9 \\
\hline CPP-2707 & + & + & + & + & 0 & + & 11 \\
\hline
\end{tabular}

Table 8. Summary Rating of Storage Facility Alternatives Grouped for Limited Capacity

\begin{tabular}{|c|c|c|c|c|c|c|c|}
\hline & 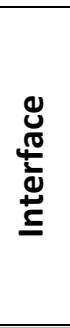 & $\begin{array}{l}\breve{ّ} \\
\tilde{0} \\
\underline{\underline{\varepsilon}}\end{array}$ & 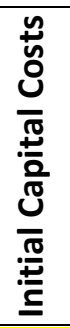 & 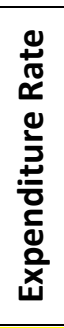 & 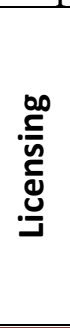 & 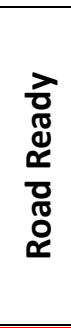 & 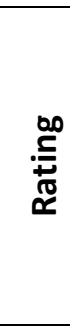 \\
\hline Modified CPP-666 & + & 0 & 0 & 0 & - & - & 5 \\
\hline Above-Grade, Large Array & + & + & - & - & - & 0 & 5 \\
\hline MFC-771 & 0 & - & + & + & 0 & - & 6 \\
\hline Modified CPP-749 & 0 & - & + & + & 0 & - & 6 \\
\hline ISFF & + & + & - & - & + & 0 & 7 \\
\hline Modified CPP-2707 & + & + & 0 & + & 0 & + & 10 \\
\hline
\end{tabular}

Table 9. Summary Rating of Storage Facility Alternatives Grouped for Unlimited Capacity

\begin{tabular}{|c|c|c|c|c|c|c|c|}
\hline & 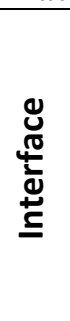 & 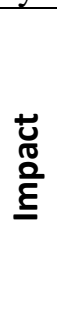 & 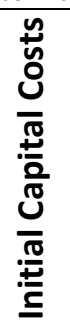 & 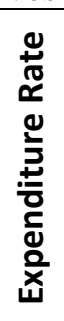 & 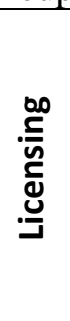 & 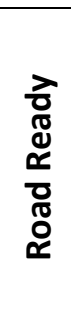 & 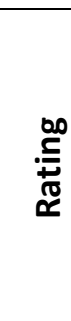 \\
\hline Above-Grade, Single Canister & + & + & 0 & 0 & - & 0 & 7 \\
\hline Below-Grade, Single Canister & + & + & 0 & + & - & 0 & 8 \\
\hline Modular Storage & + & + & 0 & + & + & 0 & 10 \\
\hline Modular Storage \& Transport & + & + & 0 & + & + & + & 11 \\
\hline
\end{tabular}

Based on considerations of various factors, including but not limited to capacity, impact to facility operations, initial capital costs, per unit costs, expenditure rate, licensing issues, and road ready conditions, new modular storage systems from commercial vendors have clear advantages over other options while looking at the entire potential inventory of DOE SNF Standardized Canisters. The use of unmodified 
existing facilities would have advantages for storing a small number of DOE SNF Standardized Canisters. The use of modified existing facilities would have advantages for storing larger numbers of DOE SNF Standardized Canisters relatively inexpensively, but with mostly upfront costs. The few advantages of a new facility are offset by its high upfront costs and delayed deployment. 


\section{References}

1. DOE/SNF/REP-011 Revision 3. Preliminary Design Specification for Department of Energy Standardized Spent Nuclear Fuel Canisters. August 1999.

2. INL/EXT-18-51490 Revision 0. Multi-Year Plan to Prepare DOE-Managed Spent Fuel for Transportation. September 2018.

3. Foster Wheeler Dwg ISF-ME-S-16000 REV 4, 18” O.D. SNF CANISTER (SHORT) FABRICATION.

4. Foster Wheeler Dwg ISF-ME-S-16002 Revision 4, 24" O.D. SNF Canister Fabrication (Long Canister).

5. SAR-114, Revision 15. Safety Analysis Report for the Irradiated Fuel Storage Facility (IFSF). June 2009.

6. SAR-113, Revision 14. Safety Analysis Report for the CPP-666 Fuel Storage Area (FSA). June 2009.

7. SAR-112, Revision 8. Safety Analysis Report for the Outdoor Fuel Storage Facility, January 2017.

8. SAR-II-8.4 Revision 6, Three Mile Island Unit 2 Independent Spent Fuel Storage Installation Safety Analysis Report, September 2018.

9. LST-340 "Outdoor Fuel Storage Facility (OFSF) Approved Cask List,"

10. SAR-407, Revision 5. Safety Analysis Report for the Radioactive Scrap and Waste Facility (MFC771). January 2018.

11. INL/EXT-16-40471 Revision 0. ATR Spent Fuel Management Options Study. January 2017

12. SAR-221, Revision 4. Safety Analysis Report (SAR) for the Idaho Spent Fuel (ISF) Facility Independent Spent Fuel Storage Installation (ISFSI). February 2010.

13. U.S. Nuclear Waste Technical Review Board. Management and Disposal of U.S. Department of Energy Spent Nuclear Fuel - A Report to the United States Congress and the Secretary of Energy. December 2017.

14. NUREG-1536 Revision 1. Standard Review Plan for Dry Cask Storage Systems. July 2010

15. ORNL/M-5003. The Radioactive Materials Packaging Handbook: Design, Operations, and Maintenance. August 1998 


\section{Appendix A}

Summary of Discussion WVDP Canister Project 


\section{Meeting Summary \\ Background:}

The West Valley Demonstration Project (WVDP) recently completed a Canister Storage Project for the storing of their High-Level Waste (HLW) glass canisters. WVDP contracted with NAC to provided 56 NAC-MPC canisters and storage over pack systems for storing HLW glass canisters at the WVDP site. Since one of the 4 different types of DOE SNF Standardized Canister designs matches the envelop dimensions of a HLW canister, INL was very interested to hear about the WVDP's experience with the Canister Storage Project. A meeting was set up with Daniel Sullivan of DOE-WVDP and Jamie Prowse of CH2M HILL BWXT West Valley (the WVDP contractor) to discuss their experience with the project.

\section{Initial Questions - Answers:}

Jamie Prowse answered the more technical questions, while Daniel Sullivan addressed the more project management questions.

1) How well did the overall project go? - Both stated the project went extraordinarily well and was a huge success.

2) What parts of the project (if any) went especially well? - The technical aspects of the project, onsite construction of shielding overpacks and delivery of MPC inner canisters went extraordinary well. MPC inner canister delivery was so efficient it had to be slowed, due to lack of onsite storage for the empty MPC inner canisters.

3) What parts of the project (if any) didn't go especially well? - Neither had any items to note that didn't go well with the project.

4) Were there any quality or safety issues/concerns? - No quality or safety issues.

5) How well did they track to their baseline schedule? - Ahead of schedule.

6) How well did they track to their cost estimate? - On budget.

7) Were there many change orders? - Contract was fixed price, so no cost change orders.

8) Were there any redesign or other major challenges during the project? How responsive was NAC to addressing the challenges? - There were no redesign with the MPC systems, the only issue came up with a design flaw in handling equipment from a subcontractor, which was completely fixed and operational again within three days. Both concluded vendor's responsiveness was outstanding.

9) Anything you would do different for the project? (i.e., any lessons learned for the project) - Nothing really identified to do different, but a couple lessons learned with positive things to do.

a. Talk to other storage system customers (WVDP had extensive discussions with Zion prior to the RFP, and the lessons learned from those helped this effort.)

b. Licensing with NRC (NRC staff does these licensing reviews of new storage/transport systems on a regular basis. It is a routine process for them, so it is more focused and rapid.)

c. Use of commercial vendors was much less programmatic risk than self-performing. The vendors are experienced with the NRC processes, so it was an Nth of a kind, rather than $1^{\text {st }}$ of a kind effort. Vendors also have existing NRC CoCs.

d. Take advantage of vendor's NRC CoCs. A Licensing Amendment was much more rapid than a completely new License.

e. Plans for/schedule to get NQA-1 subcontractors and/or get the subcontractors fully NQA1 certified beforehand. Eliminate quality issues.

10) Who other than NAC was considered, and with what products/systems did they propose? - WVDP had proposals from Holtec, NAC, and Orano-TN. All had good technical proposals.

11) Was there any specific outstanding factor (e.g., technical, cost, schedule, etc.) for selecting NAC's proposal? - NAC's technology best suited the WVDP site limitations, and their cost was good.

12) Based on the proposals you received, was there anything you would do different with the RFP if you had it to do over? (i.e., any lessons learned for the request for proposal) - No direct input on RFP to comment on. Requiring NRC Licensing was a good choice. 
13) Was there any Licensing issues? (i.e., any lessons learned with NRC licensing) - No significant Licensing issues. Did have discussions about a vertical concrete cask (VCC) seal's performance, but these were minor and quickly resolve. But whole Licensing process took only 9 months. Would have expected $24+$ months with internal processes.

14) With respect to the deployed NAC MPC technology itself, were there any operational issues (loading, inerting, sealing, inspections, etc.)? - No operational issues with the MPC.

15) Were there any remote or semi-remote seal welds used with the MPC system? - Welds were done semi-remote.

16) Were there any remote or semi-remote NDEs performed? - Only visual (remote camera) inspections were performed, since the HLW glass canisters were already a credited barrier.

17) Any lessons learned from any remote/semi-remote operations? - No lessons learned about semiremote operations.

18) What was done with regards to Licensing and/or demonstrating the future transportability capability of the MPC system? - Future transportability is via the MPC's NRC CoC.

\section{Summary of General Discussion:}

The waste forms WVDP was disposing of were canisters of HLW glass from reprocessed commercial light water reactors (each weighing $\sim 1,800 \mathrm{~kg}$ ) and canisters with SNF debris (chopped up remains of irradiated commercial PWR/BWR fuel assembly cladding, grids, and end fittings from the WVDP shear) in 55 gallon drums. The HLW glass canisters have thermal output of $100 \mathrm{~W}$ or less, and dose rates of about 2,500 R/hr at $1 \mathrm{ft}$. The sealed HLW glass canisters meet Federal repository structural and containment requirements (e.g., DOE/RW-0351).

The NAC MPC inner canisters were fabricated off-site. The MPC concrete overpacks were constructed onsite using concrete from a local supplier (located $\sim 3$ miles from the site, whom NAC worked with to become fully NQA-1 qualified). Due to the low heat load, were able to show that the concrete storage overpacks did not need cooling ports. This was a major benefit for licensing issues and maintenance issues, including worker dose.

The HLW glass canisters were loaded into the MPC canister, which was seal welded and visually inspected, before being moved out of the facility building (on air pallets), and them placed inside the concrete overpacks. A leak test (i.e., ANSI N14.5) was note required because the welded HLW glass canisters already meet the leak rate containment requirement of $1 \mathrm{E}-04 \mathrm{ref}-\mathrm{cc} / \mathrm{sec}$.

The MPC canisters hold 5 HLW canisters. The MPC canister size is consistent with the Yucca Mountain waste package sizes (WASRD). The MPC canister is semi-remotely seal welded, with a simple visual inspection of the weld via camera. The MPC canister was not dried or inerted, since they were able to show only moisture was from humidity, and humidity didn't represent a significant enough source of moisture to cause/allow significant corrosion in the canister. As an extra measure, stainless steel offstes on the bottom and sides of the MPC were used to ensure the stainless steel MPC did not contact he carbon steel liner.

The WVDP facility features/limitation were a significant factor in selecting the NAC. Some WVDP facility features meant the horizontal storage options proposed by other vendor were not viable for WVDP, and that we needed to use air pallets for some moves. Air pallets were very successfully used in moving up to 90 tons of transfer/storage overpack and loaded MPC.

A huge benefit of the project was that DOE O 1027-92 has an exception that material sealed in a type B container, the WVDP storage cask, is exempted from inclusion in the facility's materials-at-risk (MAR), resulting in the WVDP storage facility being classified as a non-nuclear facility, with corresponding reduction in reporting and security features, resulting in large cost savings. 


\section{Key Take Away Items:}

NRC licensing is beneficial. NRC Staff are experienced with licensing storage/transport systems, and the review questions mostly focused on significant areas, so overall time was greatly reduced.

Use of a commercial vendor, experienced with NRC licensing a huge benefit.

Use of vendor's NRC CoC a huge benefit.

Canister Storage Project is a huge benefit for WVDP facility operations. 